\title{
A study of faculty, administrative, and staff perceptions of the climate for shared governance at appalachian college association member institutions
}

\author{
Tanya L. Easton \\ West Virginia University
}

Follow this and additional works at: https://researchrepository.wvu.edu/etd

\footnotetext{
Recommended Citation

Easton, Tanya L., "A study of faculty, administrative, and staff perceptions of the climate for shared governance at appalachian college association member institutions" (2014). Graduate Theses, Dissertations, and Problem Reports. 223.

https://researchrepository.wvu.edu/etd/223

This Dissertation is protected by copyright and/or related rights. It has been brought to you by the The Research Repository @ WVU with permission from the rights-holder(s). You are free to use this Dissertation in any way that is permitted by the copyright and related rights legislation that applies to your use. For other uses you must obtain permission from the rights-holder(s) directly, unless additional rights are indicated by a Creative Commons license in the record and/ or on the work itself. This Dissertation has been accepted for inclusion in WVU Graduate Theses, Dissertations, and Problem Reports collection by an authorized administrator of The Research Repository @ WVU. For more information, please contact researchrepository@mail.wvu.edu.
} 
A Study of Faculty, Administrative, and Staff Perceptions of the Climate for Shared Governance at Appalachian College Association Member Institutions

Tanya L. Easton

\author{
Dissertation submitted to the \\ College of Education and Human Services \\ at West Virginia University \\ in partial fulfillment of the requirements \\ for the degree of
}

Doctor of Education

in

Higher Education Administration

Ernest R. Goeres, Ph.D., Chair

Susan A. Aloi, Ed.D

Dennis H. Stull, Ph.D.

Richard T. Walls, Ph.D.

Robert A. Waterson, Ph.D.

Department of Curriculum and Instruction/Literacy Studies, and Educational Leadership Studies

Morgantown, West Virginia

2014

Keywords: Higher Education, Shared Governance, Institutional Improvement 
A Study of Faculty, Administrative, and Staff Perceptions of the Climate for Shared Governance at Appalachian College Association Member Institutions

The purpose of this study was to investigate how faculty, administrators, and staff perceived the climate for shared governance at 36 member institutions of the Appalachian College Association (ACA), based on standards for sound shared governance in higher education as outlined by the American Association of University Professors (AAUP). Numerous reports and studies have focused on shared governance practices, but no research exists on perceptions of climate based on standards outlined by the American Association of University Professors (AAUP), which published the seminal Statement on Government of Colleges and Universities in 1966.

This study was conducted through the Appalachian College Association, a non-profit consortium of 36 independent, four-year liberal arts colleges and universities spread across the central Appalachian Mountains in Kentucky, North Carolina, Tennessee, West Virginia, and Virginia.

A total of 12 different institutions from all five states in the ACA participated in the study. Participants included faculty, staff, and administrators who were identified by their presidents or vice presidents for academic affairs as most knowledgeable about the shared governance and decision-making process on their campus. The survey, developed under the auspices of the AAUP to gauge the climate for governance, was distributed via an online link e-mailed to 480 faculty, administrators, and staff during the Fall 2013 and Spring 2014 semesters. A total of 176 survey responses were received, representing a response rate of $36.66 \%$. The 29 -item anonymous survey included three optional demographic questions, allowing respondents to indicate gender, status as tenured or non-tenured faculty member, a cabinet-level administrator or lower-level administrator, a staff member, and years in higher education.

The survey used a five-point ordinal Likert scale to indicate level of agreement--including "I don't know"-- with 26 statements about each of the following seven shared governance standards: institutional climate, institutional communication, the board's role, the president's role, the faculty's role, joint decision making, and structural arrangements. Descriptive statistics were used to analyze and describe the survey results for each of four research questions.

The results of this study indicated there were different perceptions between tenured and nontenured faculty on a number of the seven standards relative to the climate for shared governance, and between cabinet-level administrators and lower-level administrators, with the latter representing the largest group of respondents (52) in the study. Staff members' responses indicated that they were least informed about shared governance on their campuses compared to faculty and administrators. While the majority of respondents indicated there was a climate of collegiality and respect on their campuses, survey results indicated a lack of knowledge about shared governance at some ACA schools. Recommendations for practice and for research were included. 


\section{Acknowledgements}

My journey to achieve my EdD began in Fall, 2005. I could not have completed it without the support of family, friends, colleagues, and my doctoral committee:

- Special thanks to Dr. Susan Aloi, who has pushed and prodded and encouraged me every step of the way. She has been an exceptional mentor and coach, and she made it her personal mission to get me through.

- Dr. Ernie Goeres has been a steady and welcome presence in my graduate education since my master's class with him on higher ed finance in the 1980s. He is a treasure to the University and to every student who has had the good fortune to have had him on their side.

- Dr. Dennis Stull was a beloved Provost/VPAA and respected former colleague at AB College, and I have felt privileged to have his support (now from afar) throughout my doctoral work.

- Dr. Waterson graciously agreed to help me out by joining my committee last year, and I appreciate his willingness to give of his time and expertise, even though we have never met.

- Dr. Walls has been a rock star in helping me through the IRB approval process and facing up to the technological challenges of the Kuali Portal system. He has always been responsive and helpful whenever I have asked, and I will always be grateful.

A number of presidents for whom I have worked have also been instrumental in supporting me, encouraging me, and giving me the freedom to pursue my doctoral studies: Dr. Pam Balch at West Virginia Wesleyan, and Dr. Richard Creehan and Dr. Steve Markwood at AldersonBroaddus University, outstanding leaders and mentors from whom I learned a great deal.

I am grateful to my mother, Beth Kittle, and my late father, Howard Kittle, who provided my foundation for lifelong learning, beginning with my childhood trips to the library to pick out books. Final thanks also to my husband, Ed, who has provided chastisement at the appropriate moments to keep me motivated to finish, and to my son, Nathan Shelton, whose encouragement and understanding as a new graduate student himself has been especially meaningful.

Thank you all. 


\section{Table of Contents}

Table of Contents ........................... iv

List of Tables $\ldots \ldots \ldots \ldots \ldots \ldots \ldots \ldots \ldots \ldots \ldots \ldots \ldots \ldots \ldots \ldots \ldots \ldots$

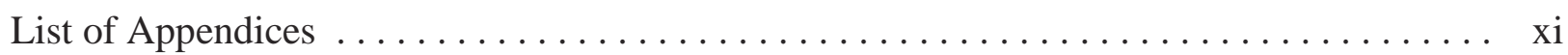

Chapter One: Statement of the Problem . . . . . . . . . . . . . . . . . 1

Purpose of the Study and Research Questions $\ldots \ldots \ldots \ldots \ldots \ldots \ldots \ldots$

Significance of the Study . . . . . . . . . . . . . . . 6

Chapter Two: Review of the Literature $\ldots \ldots \ldots \ldots \ldots \ldots \ldots \ldots \ldots \ldots$

Historical Context . . . . . . . . . . . . . . . . . . 9

Linkage of Shared Governance and Academic Freedom $\ldots \ldots \ldots \ldots \ldots \ldots$

Influences of Changing Higher Education Environment on Shared Governance . . . 15

Deprofessionalization of the Faculty. . . . . . . . . . . . 17

Calls for Corporate Management Model . . . . . . . . . . . . . . 18

Increase in Non-faculty Appointments . . . . . . . . . . . . . . . . . . 19

Campus Influences on Shared Governance $\ldots \ldots \ldots \ldots \ldots \ldots \ldots \ldots \ldots \ldots \ldots \ldots$

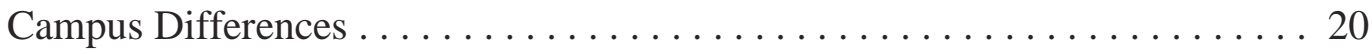

Competing Conceptions $\ldots \ldots \ldots \ldots \ldots \ldots \ldots \ldots \ldots \ldots \ldots \ldots \ldots$

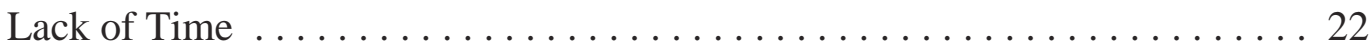

Lack of Mutual Understanding and Respect .............. 23

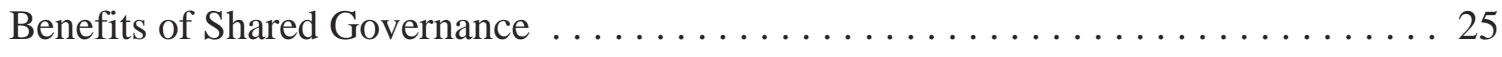

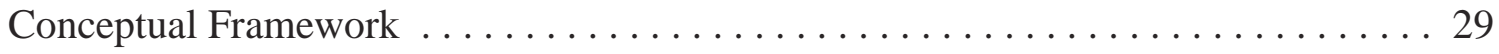

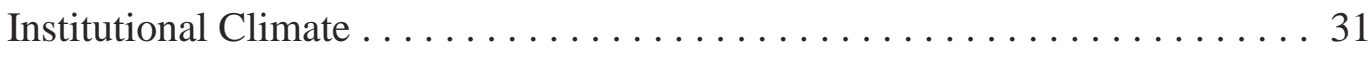

Institutional Communication $\ldots \ldots \ldots \ldots \ldots \ldots \ldots \ldots \ldots \ldots \ldots \ldots \ldots \ldots \ldots$ 
The Role of the President . . . . . . . . . . . . . . . . . . . 33

The Role of the Governing Board . . . . . . . . . . . . . . . . . . 34

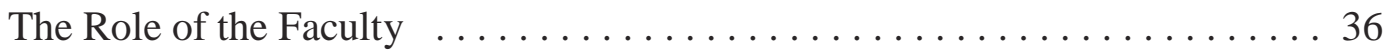

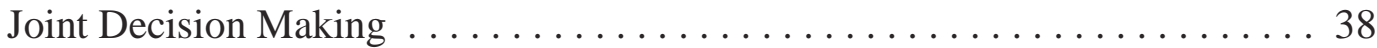

Structural Arrangements . . . . . . . . . . . . . . . . . 40

Climate for Shared Governance $\ldots \ldots \ldots \ldots \ldots \ldots \ldots \ldots \ldots$

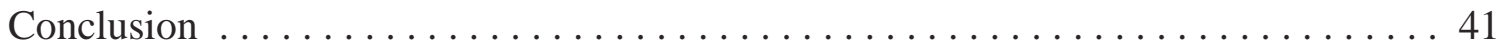

Chapter Three: Method $\ldots \ldots \ldots \ldots \ldots \ldots \ldots \ldots \ldots \ldots \ldots \ldots \ldots \ldots \ldots \ldots \ldots \ldots \ldots$

Research Questions .............................. 42

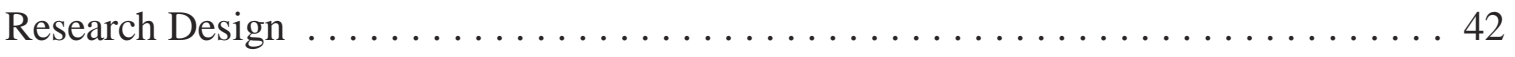

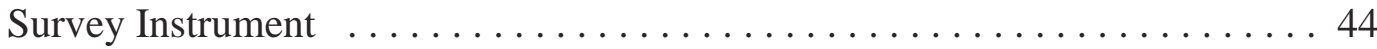

Demographic Items . . . . . . . . . . . . . . 45

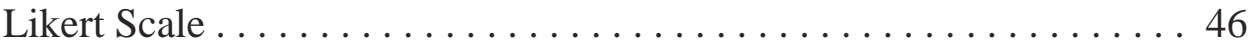

Population and Sampling $\ldots \ldots \ldots \ldots \ldots \ldots \ldots \ldots \ldots$

Population of Interest $\ldots \ldots \ldots \ldots \ldots \ldots \ldots \ldots \ldots \ldots \ldots \ldots$

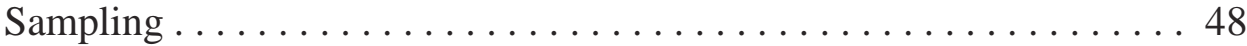

Survey Administration Procedure and Timeline . . . . . . . . . . . . . . 49

E-mail Addresses . . . . . . . . . . . . . . . . . . . 49

Contacts with Participants $\ldots \ldots \ldots \ldots \ldots \ldots \ldots \ldots \ldots$

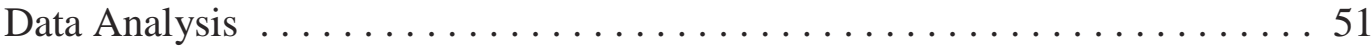

Limitations, Delimitations, and Strengths $\ldots \ldots \ldots \ldots \ldots \ldots \ldots \ldots \ldots \ldots \ldots \ldots \ldots \ldots \ldots$

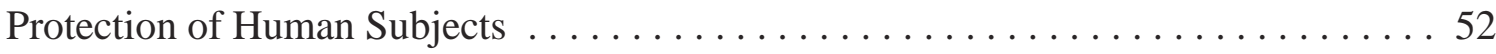

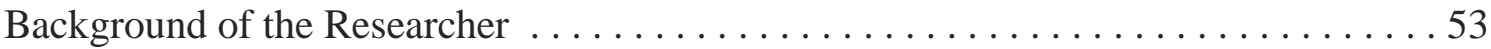




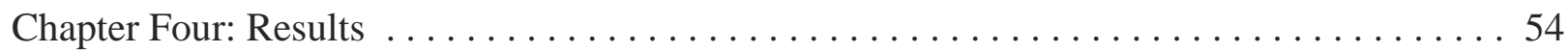

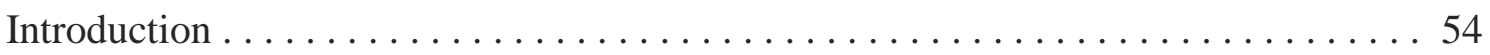

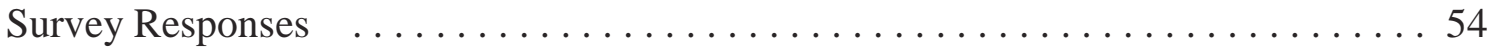

Demographic Information of Study Participants $\ldots \ldots \ldots \ldots \ldots \ldots \ldots \ldots \ldots$

Findings from the Research Questions ...................... 56

Findings from Research Question $1 \ldots \ldots \ldots \ldots \ldots \ldots \ldots \ldots$

Institutional Climate $\ldots \ldots \ldots \ldots \ldots \ldots \ldots \ldots \ldots \ldots \ldots$

Institutional Communication ................... 58

The Board's Role $\ldots \ldots \ldots \ldots \ldots \ldots \ldots \ldots \ldots \ldots \ldots \ldots$

The President's Role ............................... 60

The Faculty's Role .......................... 61

Joint Decision Making ........................ 63

Structural Arrangements ........................... 64

Findings from Research Question $2 \ldots \ldots \ldots \ldots \ldots \ldots \ldots \ldots \ldots$

Institutional Climate $\ldots \ldots \ldots \ldots \ldots \ldots \ldots \ldots \ldots \ldots \ldots$

Institutional Communication ................... 68

The Board's Role .......................... 68

The President's Role .............................. 69

The Faculty's Role ........................... 70

Joint Decision Making $\ldots \ldots \ldots \ldots \ldots \ldots \ldots \ldots \ldots \ldots \ldots \ldots \ldots$

Structural Arrangements ........................ 73

Findings from Research Question $3 \ldots \ldots \ldots \ldots \ldots \ldots \ldots \ldots \ldots$ 
Institutional Climate $\ldots \ldots \ldots \ldots \ldots \ldots \ldots \ldots \ldots$

Institutional Communication $\ldots \ldots \ldots \ldots \ldots \ldots \ldots$

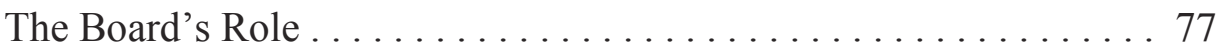

The President's Role ....................... 78

The Faculty's Role . . . . . . . . . . . . . . . . . . . . 79

Joint Decision Making $\ldots \ldots \ldots \ldots \ldots \ldots$

Structural Arrangements . . . . . . . . . . . . . . . . 81

Findings from Research Question $4 \ldots \ldots \ldots \ldots \ldots \ldots 2$

Institutional Climate . . . . . . . . . . . . . . . 82

Institutional Communication $\ldots \ldots \ldots \ldots \ldots$

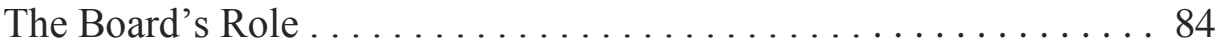

The President's Role ...................... 85

The Faculty's Role ...................... 87

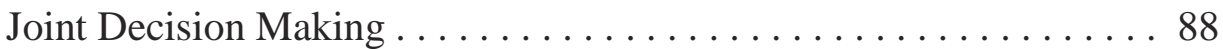

Structural Arrangements . . . . . . . . . . . . . . . 90

Chapter Five: Summary, Conclusions, and Recommendations . . . . . . . . . . . 92

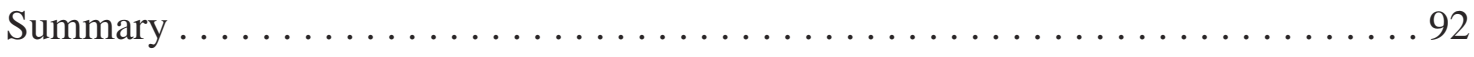

Conclusions from Research Questions . . . . . . . . . . . . . . . . 93

Research Question \#1 Conclusion $\ldots \ldots \ldots \ldots \ldots \ldots \ldots$

Research Question \#2 Conclusion $\ldots \ldots \ldots \ldots \ldots \ldots \ldots \ldots \ldots$

Research Question \#3 Conclusion . . . . . . . . . . . . . . . . 96

Research Question \#4 Conclusion . . . . . . . . . . . . . . 97

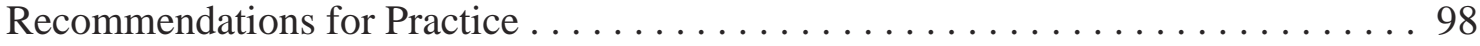


Recommendations for Future Research . . . . . . . . . . . . . . . . . . 104

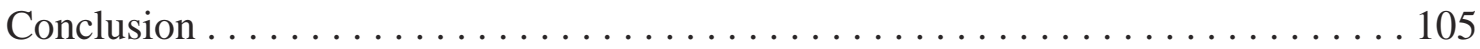

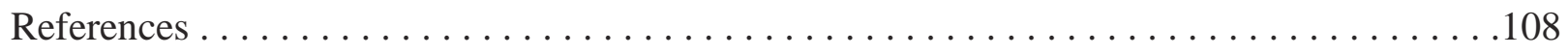

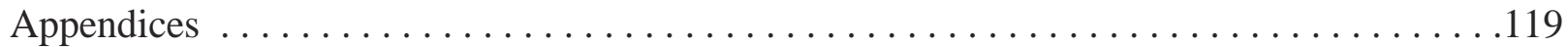




\section{List of Tables}

Table 1 Relationship of Standards for Shared Governance to Research Questions . . . . . . . 45

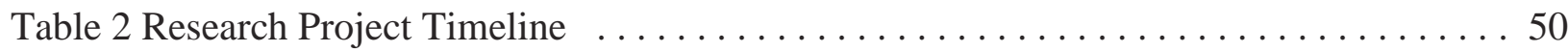

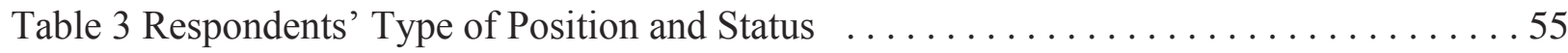

Table 4 Respondents' Years in Higher Education . . . . . . . . . . . . . . . . 56

Table 5 Faculty Perceptions - Institutional Climate $\ldots \ldots \ldots \ldots \ldots \ldots \ldots \ldots$

Table 6 Faculty Perceptions - Institutional Communication $\ldots \ldots \ldots \ldots \ldots \ldots \ldots$

Table 7 Faculty Perceptions - Board's Role . . . . . . . . . . . . . . . . . . 59

Table 8 Faculty Perceptions - President's Role . . . . . . . . . . . . . . . . . 61

Table 9 Faculty Perceptions - Faculty's Role $\ldots \ldots \ldots \ldots \ldots \ldots \ldots \ldots \ldots \ldots \ldots \ldots \ldots \ldots$

Table 10 Faculty Perceptions - Joint Decision Making $\ldots \ldots \ldots \ldots \ldots \ldots \ldots \ldots$

Table 11 Faculty Perceptions - Structural Arrangements $\ldots \ldots \ldots \ldots \ldots \ldots$

Table 12 Administrator Perceptions - Institutional Climate . . . . . . . . . . . 67

Table 13 Administrator Perceptions - Institutional Communication . . . . . . . . . . 68

Table 14 Administrator Perceptions - Board's Role . . . . . . . . . . . . . . . . . 69

Table 15 Administrator Perceptions - President's Role $\ldots \ldots \ldots \ldots \ldots \ldots \ldots \ldots \ldots$

Table 16 Administrator Perceptions - Faculty's Role $\quad \ldots \ldots \ldots \ldots \ldots \ldots \ldots \ldots \ldots \ldots 71$

Table 17 Administrator Perceptions - Joint Decision Making . . . . . . . . . . 73

Table 18 Administrator Perceptions - Structural Arrangements . . . . . . . . . . . . 75

Table 19 Staff Perceptions - Institutional Climate $\ldots \ldots \ldots \ldots \ldots \ldots \ldots \ldots$

Table 20 Staff Perceptions - Institutional Communication $\ldots \ldots \ldots \ldots \ldots \ldots \ldots \ldots \ldots 77$ 
Table 21 Staff Perceptions - Board's Role $\ldots \ldots \ldots \ldots \ldots \ldots \ldots \ldots \ldots$

Table 22 Staff Perceptions - President's Role . . . . . . . . . . . . . . . . . . . 79

Table 23 Staff Perceptions - Faculty's Role $\ldots \ldots \ldots \ldots \ldots \ldots \ldots \ldots \ldots$

Table 24 Staff Perceptions - Joint Decision Making . . . . . . . . . . . . . 81

Table 25 Staff Perceptions - Structural Arrangements $\ldots \ldots \ldots \ldots \ldots \ldots \ldots$

Table 26 Perceived Shared Governance Climate at ACA Schools - Institutional Climate . . . 83

Table 27 Perceived Shared Governance Climate at ACA Schools -

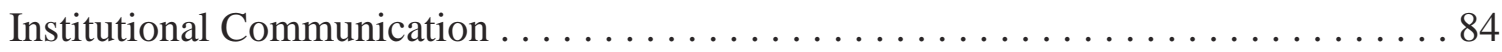

Table 28 Perceived Shared Governance Climate at ACA Schools - Board's Role . . . . . . 85

Table 29 Perceived Shared Governance Climate at ACA Schools - President's Role . . . . . 86

Table 30 Perceived Shared Governance Climate at ACA Schools - Faculty's Role . . . . . 87

Table 31 Perceived Shared Governance Climate at ACA Schools - Joint Decision Making . 88

Table 32 Perceived Shared Governance Climate at ACA Schools - Structural Arrangements . 89 


\section{List of Appendices}

Appendix A Survey Instrument . . . . . . . . . . . . . . . . . . . . . . . . . . 119

Appendix B Approval Letter from Appalachian College Association . . . . . . . . . . . 126

Appendix C Approval Letter from WVU IRB $\ldots \ldots \ldots \ldots \ldots \ldots \ldots \ldots \ldots \ldots$

Appendix D Introduction of Research Study by ACA President . . . . . . . . . . . 128

Appendix E Request for Approval to Conduct Research Study . . . . . . . . . . . . . . . 129

Appendix F Reminder Request for Approval to Conduct Study . . . . . . . . . . . . . . 130

Appendix G Request for Individual Participation in Research Study w/Survey Link . . . . . 131

Appendix H Reminder Request for Research Study Participation . . . . . . . . . . . . . . . 132 


\section{Chapter One: Statement of the Problem}

Sparked by recent crises, higher education governance is receiving heightened attention across the country. These crises include the forced resignation of the president at the University of Virginia, and the reported cover-up of child sexual abuse by a former assistant coach at The Pennsylvania State University (Bornstein, 2012).

Former Harvard president and higher education author Derek Bok (2013) said, "In a country with 4,500 colleges and universities, however, it is hazardous to reach conclusions about governance by citing problems on a handful of campuses. A broader and more careful inquiry is required" (para. 4).

Shared institutional governance has been a hallmark of American colleges and universities for over a generation (Center for Higher Education Policy Analysis [CHEPA], 2003). It has been noted that "Shared governance is to higher education what mom and apple pie are to American culture" (Tierney, 2004a, p. 202). The tradition of shared governance rests on the assumption that faculty should hold a substantive role in decision-making, along with governing boards and administration.

More specifically, the American Association of University Professors (AAUP), in its 1966 seminal Statement on Government of Colleges and Universities, makes the following case for shared governance in the academy:

The variety and complexity of the tasks performed by institutions of higher education produce an inescapable interdependence among governing board, administration, faculty, students, and others. The relationship calls for adequate communication among these components, and full opportunity for appropriate joint planning and effort. (AAUP, 1966, Preliminary Considerations section, para. 1) In spite of their important national and international role in society, today's American colleges and universities continue to face an array of challenges, including calls for a new, more 
efficient way of administering our institutions of higher education that is more in keeping with corporate management models (American Federation of Teachers [AFT], 2006). Higher education literature (AFT, 2006; Association of Governing Boards [AGB], 2009a; Knapp \& Siegel, 2009; Tierney, 2006) outlines the following assertions about why change is needed in the governance traditions of the academy:

- the rapid technological changes taking place - computerization, the Internet, webbased courses — require adaptability;

- the marketplace of higher education is rapidly changing, with wholly online institutions and for-profit universities creating competitive challenges to our traditional ways;

- faculty are too slow to make decisions to adapt to change and cling to outmoded models of deliberation and reflection when action is required;

- faculty resist efforts to keep the curriculum up to date;

- the tenure system stands as an obstacle to greater accountability and improved performance.

Because an ever-growing number of board members and administrators with this mindset have reached positions of responsibility on campus, the practice of shared governance in higher education is increasingly being questioned (AFT, 2006; Tierney \& Lechuga, 2004; Zemsky, 2009). The literature affirms that there is a feeling among not only boards but also political leaders that any sharing of authority impedes the ability to make important decisions effectively and efficiently (AFT, 2006; AGB, 2009b; CHEPA, 2003).

Wellman (2006) highlights the evolution of higher education governance by noting that it has become increasingly complicated: 
Faculty capacity to control academic policy has obviously eroded, along with the thinning ranks of full-time tenured faculty. Boards have grown, resources have become more fragmented, unionization is more common, and professional managers often outlast presidents, board members, and even faculty. (p.53) Additional research (CHEPA, 2003) indicates two key findings regarding the effectiveness of traditional governance practices: (1) apathy and lack of trust are significant barriers to meaningful faculty participation in shared governance, and (2) differential perceptions of shared governance lead to expectations of ineffective governance.

George Keller (2001) notes:

Governance: the word itself is ambiguous. It implies administration of the affairs of an organization, as in a well-governed hospital. It also implies tight control, as in a valve that governs the steam intake, or major influence, as in an expert coach often governs the outcome of a game. It connotes management, as in the governance of a state's higher education system. (p. 304)

The disagreement about what shared governance actually means centers around the following--whether it is (or should be) fully collaborative decision-making, consultative decision-making, or distributed decision-making (CHEPA, 2003, p. 4). These terms are explained more fully in the literature review.

In a national survey of 2,000 faculty and provosts at 763 four-year baccalaureate, master's, and doctoral institutions, respondents held different views on the role of shared governance: $47 \%$ indicated that shared governance was defined as fully collaborative, $27 \%$ indicated that it was consultative decision-making, and $26 \%$ held that it was distributed decisionmaking. As the author notes, "The presence of these various interpretations is important because 
strife and conflict are likely to appear when individuals on a campus have dissimilar views about shared governance" (CHEPA, 2003, p. 4).

The CHEPA study (2003) also cites inadequate communication among faculty and administrators as a hindrance to collegial governance:

Colleges and universities exist in loosely coupled environments. A mistaken tendency is to try to tighten the loose coupling. Instead, accept that our institutions exist in decentralized organizations and that the faculty's engagement with an issue may be sporadic. A key to effective governance is to communicate consistently with the faculty. (p. 12)

At the same time, research reveals that college and university presidents, chief academic officers, and board chairs view faculty-board engagement and relations as generally constructive (Schwartz, Skinner, \& Bowen, 2009). Defenders of the faculty's role in shared governance contend that faculty involvement in decision making has positive effects on academic freedom and educational quality. They maintain that the university is not merely a business, but that it is one of the world's oldest organizations and has withstood various external pressures, including those of a changing marketplace, by a deliberative and consensual decision making approach (CHEPA, 2003). As noted by Smith (2009), "Shared governance in higher education, with its roots in long-held principals of collegiality, is in profound historical conflict with any tinge of modern political or authoritarian top-down business models of leadership" (Abstract section, para. 1). Tanner \& Palfreyman (2010) ask a pertinent question:

However, the conceptual difficulty, which all analysts (including ourselves) have to address, is that collegiality is a socially constructed concept, and thus its meaning is always problematic. What has to change or be sustained before we can evaluate its 
strength? Does it make sense to retain the idea of collegiality in the context of senior management groups, the commitment to strong institutional leadership and speedy decision making? (p. 13)

In spite of the complexities of the higher education system, the calls for change, and the confusion about the meaning of shared governance, there remain themes about the value of shared governance that persist in the literature. These themes include a commitment to governance that protects individual autonomy, respect for decentralization of control and shared governance with faculty, and support for boards that play a role of both bridge to external groups and buffer against political interference in academic decision-making. According to Wellman (2006), “Above all, governance is supposed to protect institutions from short-term political trends, ensure stability, and guard the institution from intellectual fads or inappropriate control of the institution by single-interest groups" (p. 53).

\section{Purpose of Study and Research Questions}

The purpose of this study was to investigate how faculty, administrators, and staff perceived the climate for shared governance at 36 member institutions of the Appalachian College Association, based on standards for sound shared governance in higher education as outlined by the American Association of University Professors (AAUP).

Research was conducted by surveying campus constituents' knowledge about governance and decision-making processes at their respective institutions of higher education. This research was based on the premise that the 1966 AAUP statement remains pertinent today in its assertion about the essential nature of shared governance in the academy, with affirmation in the current literature that it is valued by and valuable to institutions of higher education (CHEPA, 2003; AGB, 2009a). 
Research focused on the following questions:

1. What are faculty members' perceptions of the climate for shared governance at their institutions?

2. What are administrators' perceptions of the climate for shared governance?

3. What are staff members' perceptions of the climate for shared governance?

4. What is the perceived climate for shared governance at ACA institutions based on their aggregated responses?

\section{Significance of the Study}

In a discussion paper prepared for the Center for Collaborative Policy, Leach noted, "Never has the need for effective academic governance been greater than in today's rapidly changing environment" (Leach, 2008, p. 3). The literature on college and university governance is dominated by structural and organizational analyses that focus on identifying different actors involved in governance and their respective roles and responsibilities. Wellman (2006) notes: The literature is more descriptive than normative, in that it is largely more devoted to functional characterizations of how the systems work rather than on how they should work. Despite much debate about language — parsing the meaning of shared governance is a favorite topic - there is not much to be construed from the literature that could pass for principles of good or effective governance (p. 36).

Shared governance has historically been an important hallmark of the decision-making process for independent institutions of higher education. Because there have been no studies of the shared governance process at institutions in the Appalachian College Association, which represents a unique consortium of independent institutions, this study represents an opportunity 
to understand the current climate for shared governance in the ACA. The study may provide a springboard for additional study regarding best practices for shared governance. 


\section{Chapter Two: Review of the Literature}

For the last 75 years, shared governance has been the overriding principle that guides decision making in American colleges and universities (Kezar, Lester, \& Anderson, 2006), and Morphew (1999) notes that "shared governance is, inarguably, one of the aspects of the American college that defines this institution" (p. 78). In this concept, faculty, administrators, and trustees have traditionally shared responsibility for governance as outlined by the American Association of University Professors (AAUP) in its first statement on the subject in 1920.

Various authors have provided extensive literature reviews and treatments of the history, perceptions, and practices of shared governance in higher education (Eckel \& Kezar, 2003; Leach, 2008; Rashdall, 1936; Rosser, 2002; Rosser, 2003). However, while the concept is deeply rooted in the system of higher education, it has been met with increasing questions about the faculty's role in governance, and whether the practice inhibits effective and efficient decision making in the academy (AFT, 2006).

In order to systematically provide a foundation for understanding the nature of shared governance in higher education, its origins and its practice, this literature review is organized as follows: the first section defines the concept, outlines the historical background and evolution of shared governance, and explains the interrelatedness of shared governance and academic freedom. The second section describes how the changing landscape of higher education influences the practice of shared governance, and the third section is a discussion of campus obstacles. The fourth section provides a rationale for continuing the practice of shared governance in higher education based on its benefits to institutions and to the public good. The fifth and final section outlines appropriate roles for participants in the shared governance process at independent colleges, and explains the broad principles of sound shared governance. 


\section{Historical Context}

The modern American version of shared governance in higher education is intertwined with European origins and development of collegiality as early as the $13^{\text {th }}$ Century. Rashdall (1936) wrote that contemporary universities in Europe and America could only be understood by considering distinctly medieval institutions. He suggested that medieval higher learning embodied three important educational premises which are still valued: a commitment to providing useful professional training with the highest intellectual cultivation possible; a desire to conserve and transmit knowledge by advancing research and writing; and the joining together of teachers in diverse subjects in order to make the teaching body representative of the whole cycle of knowledge.

Smith (2009) explains that this interaction among scholars describes the origin of collegiality in higher education. More specifically, he says, an "ideal shared governance model is collegial in nature, recognizing the contributions and requirements of all members of the college in a group consensus process. This process fosters a sense of empowerment, equal partnership, and a vested interest in successful outcomes of institutional policy and implementation decisions" (Introduction section, para. 4).

The notion of shared governance that exists today has continued to evolve over time as governing boards, faculty, and administrators have sought authority over specific portions of their organizations. The colonial American college generally vested in its governing board and college president exclusive authority over the operations of the college. The president was placed in charge of a range of daily duties important to the college's successful operation and "tended to function as an authority unto himself" (Lucas, 1994, p. 124). This arrangement was not original 
to the American college. Rather, it was imported from the English collegiate model and "illustrated the lack of faith college founders and trustees had in their faculty" (Morphew, 1999, p. 26).

Faculty dissatisfaction with this model of governance helped to bring about its end and the evolution toward the concept of shared governance that is embraced as part of the modern American collegiate model. An important portent of this evolution — and of the conception of the American college that dominates today-occurred at Harvard in 1825. Because of their general discontent with the administration and the curriculum of the colonial college, faculty protests earned them the right of internal control over the discipline of the students and the direction of instruction (Brubacher \& Rudy, 1997).

This concept is mirrored in AAUP's definition of shared governance as follows:

One of the key tenets of quality higher education, this term refers to governance of higher education institutions in which responsibility is shared by faculty, administrators, and trustees. The AAUP emphasizes the importance of faculty involvement in personnel decisions, selection of administrators, preparation of the budget, and determination of educational policies. Faculty should have primary responsibility for such fundamental areas as curriculum, subject matter and methods of instruction, research, faculty status, and those aspects of student life which relate to the educational process, according to the Statement on Governance of Colleges and Universities. (AAUP, n.d., Informal Glossary of AAUP Terms and Abbreviations section, para. 44)

The AAUP statement on shared governance in higher education, with its call for shared responsibility among the different components of institutional government and its specification 
of areas of primary responsibility for governing boards, administration, and faculties, remains the Association's central policy document relating to academic governance. It has been supplemented over the years by a series of derivative policy statements, including those on faculty governance and academic freedom, budgetary and salary matters, financial exigency, the selection, evaluation, and retention of administrators, college athletics, governance and collective bargaining, and the faculty status of college and university librarians (AAUP, 2006).

Birnbaum (2003) explains that governance is the term we give to the structures and processes that academic institutions invent to achieve an effective balance between the claims of two different, but equally valid, systems for organizational control and influence. One system, based on legal authority, is the basis for the role of trustees and administration; the other system, based on professional authority, justifies the role of the faculty. The importance of legal authority was recognized with the founding of our first colleges. The acceptance of the role of professional authority is a more recent phenomenon that has evolved over time.

The original argument for faculty participation emphasized only their competence to deal with strictly academic matters. However, the increasing professionalism of the faculty during the early decades of the $20^{\text {th }}$ century, accelerated by the academic revolution following World War II, led at many institutions not only to faculty control over the curriculum but to a strong faculty voice in other education-related matters as well (Birnbaum, 2003).

In addition, the board's role in institutional governance has undergone a parallel evolution. Spencer (as cited in Birnbaum, 1988, p. 204) notes that the campus unrest and fractious activities of faculty and students on campuses in the 1960s and 1970s "forced governing boards to abandon the 'absentee landlord' role in favor of responsible participation in college affairs." He suggests that until that time, the board's perceived role was "to hire and fire 
the president," who had to learn to "consult others and learn to operate by suggestion and persuasion rather than direction" (p. 205). Spencer explains how the board's role was dramatically altered as well:

The public, too, had been accustomed to the idea that a college or university president ran the institution and spoke with complete authority on campus affairs. The upheavals of the Vietnam War era, with embattled presidents locked out of their offices, shook this image to its foundations. Trustees could no longer sit back in the comfortable assurance that presidents had matters well in hand. As events on campus increasingly engaged the attention of the public, it became painfully clear that trustees themselves could not avoid involvement. (Birnbaum, 1988, p. 205)

The publication in 1966 of the canonical Statement on Government of Colleges and Universities (AAUP, 1966), jointly formulated by three national associations and therefore often referred to as the Joint Statement, for the first time formally articulated and legitimated the faculty role in academic governance. Describing the essential relationship among trustees, presidents, and faculty as based on mutual understanding, joint effort, and inescapable interdependence, the Joint Statement laid out two basic principles of shared governance: 1) important areas of action involve at one time or another the initiating capacity and decisionmaking participation of all the institutional components, and (2) the difference in the weight of each voice, from one point to the next, should be determined by the reference to the responsibility of each component for the particular matter at hand.

Not only did the Joint Statement confirm the faculty's primary responsibility for educational matters such as faculty status, and programs of instruction and research, but it also articulated the importance of faculty involvement in educational policy more generally, including 
the setting of institutional objectives, planning, budgeting, and the selection of administrators (AAUP, 2006).

This notion of shared governance, including the idea that faculty have primary authority over the instruction and evaluation of their students, "has so thoroughly permeated the American higher education landscape that today it remains the normative means of governing a college" (Morphew, 1999).

\section{Linkage of Shared Governance and Academic Freedom}

In 1994, the American Association of University Professors (AAUP) adopted a policy statement, On the Relationship of Faculty Governance to Academic Freedom. The statement asserted that these two principles - faculty governance and academic freedom — are "inextricably linked," so that "neither is likely to thrive except when they are understood to reinforce one another" (Gerber, 2001, Academic Freedom section, para. 1). This statement further underlined that the close connection between academic freedom and faculty governance was reflected in the earliest work of the AAUP.

In 1915, the first year of its existence, the AAUP established the "Committee A on Academic Freedom and Academic Tenure." At its annual meeting the following year, the members of the association voted to create "Committee T on the Place and Function of Faculties in University Government and Administration" (now called the Committee on College and University Governance). These earliest AAUP statements on academic freedom articulate the role of faculty governance as the institutional basis for academic freedom and for the identification of appropriate boundaries for the exercise of that freedom (Gerber, 2010). 
According to the AAUP's 1994 statement On the Relationship of Faculty Governance to Academic Freedom, these two principles have always been "closely connected, arguably inextricably linked" (AAUP, 1994, p. 48). Gerber (2001) notes:

It is hard to imagine effective governance if faculty do not enjoy the right to speak freely without fear of reprisal on issues relating to their own institutions and policies, but it is equally true that shared governance, along with tenure, are the two principal institutional bulwarks for academic freedom. (Academic Freedom section, para. 1)

In his essay, The Limits of Academic Freedom, Louis Menand went further in linking academic freedom to governance, noting that academic freedom was "the key legitimating concept of the entire academic enterprise" (1998, p. 4). Without academic freedom, he argued, governance would be a "political free-for-all, in which decisions about curricula, funding, employment, classroom practice, and scholarly merit are arrived at through a process of negotiation among competing interests" (p. 4).

According to Gerber (2010), the concept of shared governance accommodates the wide differences in history, size, and complexity of American higher education. Governance processes at liberal arts colleges are distinctive in that the whole faculty is often involved in governance; at larger institutions such as doctoral-and masters-granting institutions, governance tends to be a representative process through a faculty senate and joint committees. At community colleges, unions are also a key factor in the process. Although academic governance has changed over time, becoming highly participatory in the 1960s and more hierarchical in the 1980s, it has historically retained the notion of the importance of consultation and participation of campus constituents in major decision making, reflecting democratic principles. 


\section{Influences of a Changing Higher Education Environment on Shared Governance}

Throughout its history, there has been growing consensus that important changes to the academy are those that are external to it. "Institutions are certainly influenced by powerful, external factors such as demographic, economic, and political conditions" (Tierney,1988, p. 3). Several observers have noted that these conditions should be considered when discussing more effective internal governance processes (Kerr, 1994; Newman, Couturier \& Scurry, 2001).

Mortimer and Sathre (2007) note that at least seven major forces impact the governance of higher education, and suggest that the institutional response to these demands must be considered in light of specific contextual and cultural factors (p. 43):

- the rising importance of market forces;

- the demands for accountability;

- the increasing volatility of state- and system-level actions;

- the integration of the university into the larger society;

- the changing nature of student populations;

- the globalization of science and technology; and

- the increased importance of educational technology.

According to Mortimer and Sathre (2007), participants in shared governance face the following realities: external forces are changing faster than internal governance values and processes can adapt, academic goals and missions are ambiguous, and conflict over them is normal. They note that "decisions are not made; instead, they flow; participation in governance is fluid, particularly on the big issues, and interests of the stakeholders (e.g., job security, salaries, professional control) are legitimate concerns in the debate about governance” (p. 44). 
The same challenges are echoed in Birnbaum's classic 1988 text How Colleges Work:

"American colleges and universities are the most paradoxical of organizations. On the one hand, it has been said that they constitute one of the largest industries in the nation but are among the least businesslike and well managed of all organizations" (p. 3).

In some of the professional functions of colleges/universities, the values of professional control approach the ideal type represented by the term collegium:

Academic departments tend to be the chief decision unit for promotions, teaching assignments, the shape of the curriculum in the major, and whether students are treated as active learners or vessels into which knowledge is poured. Academic departments are key units in protecting the professional control structure that characterizes academic organizations and makes them unique organizational types. In some respects, campus faculty senates and separate college/school senates further this manifestation of professional control. Most observers believe that the set of values represented by this professional control is a legitimate basis on which governance can rest. For the most part, criticisms of the academy do not recommend that professional control be eliminated, but rather that it be modified. (Mortimer \& Sathre, 2007, p. 113)

Mortimer \& Sathre (2007) add, "However, the impact of universal postsecondary education, rising market forces, increased calls for entrepreneurship, and the need to adopt mission-centered, market-smart strategies constitute a confusing environment for the traditional shared governance process" (p. 1).

Rhoades (2005) calls for an academy that is democratically engaged with and accountable to more diverse constituents. Newman, Couturier and Scurry (2004) refer to an academy more sensitive to the changing nature of the external environment. Kirp (2003) 
notes that the forces of the market bring inappropriate pressure on the academy

and, in some cases, this pressure results in bad educational decisions. And Gumport (2001) calls for collaboration in support of the common good and the importance of protecting an institution's educational and social justice values.

There is contradictory evidence about what has happened to the practice of shared governance since 1970. A comprehensive survey of governance practices, conducted in 2001 by Gabriel Kaplan with the cooperation of the AAUP, found that faculty involvement in hiring and promotion, and the selection of deans and department chairs, appeared to be substantially greater in 2001 than it had been thirty years earlier, while faculty control over curriculum and degree requirements, which had already been well established in 1970, had been even further solidified (Gerber, 2010).

On the other hand, several developments in recent decades have been purported to undermine the basis of faculty self-governance and the foundation upon which academic freedom in American colleges and universities rests (Firkin \& Post, 2009). The following sections outline those contributing factors in the rapidly changing higher education environment.

Deprofessionalization of faculty. Over the past 30 years, there has been a rapidly accelerating deprofessionalization of the faculty at American colleges and universities, most clearly reflected in the rapid expansion of contingent appointments. Gerber (2010) suggests that this has seriously eroded the institutions of tenure and faculty governance, and thereby undermined the basic protections of academic freedom and the quality of American higher education.

In 1975 , those working full time made up $70 \%$ of all faculty, and of those, $57 \%$ were tenured or tenure track. By 2005, the increasing use of casual labor that had come to characterize 
much of the American labor market with the end of the postwar economic boom had affected the professoriate. Of the more than one million faculty members in the United States in 2005, nearly half $(48 \%)$ worked only part time, and less than one-third (32\%) were tenured or tenure track.

More faculty were becoming contingent employees rather than career professionals who enjoyed job security and a good deal of autonomy (Gerber, 2010).

There are resulting implications for faculty governance and academic freedom. Tenure was developed as a safeguard for academic freedom, without which it has been asserted that faculty could not carry out their professional responsibilities. At-will and part-time faculty employees lack the professional status and protections of their tenured colleagues. Out of concern for their continued employment, they are more likely to engage in self-censorship in their teaching and research (Gerber, 2010).

Gerber (2010) notes, “Although many non-tenure-track faculty have begun, with the support of the AAUP, to lay claim to a role in institutional governance, their lack of job security, frequent part-time status, and the fact that many part-time faculty work at more than one institution to earn a living, makes such participation problematic (p. 21).

Calls for corporate management model. An indication of the weakening support for the principles of shared governance set forth in the 1966 Statement on Government was the 1996 publication by the Association of Governing Boards of Colleges and Universities (AGB) of a major report that was characterized as "a partial repudiation of the earlier document in whose formulation it had participated" (Gerber, 2010, p. 22). The AGB commission that drafted Reviewing the Academic Presidency: Stronger Leadership for Tougher Times claimed that the "tradition of shared governance needed to be reshaped, not scrapped" (AGB, 1996, p. 2). 
Its recommendations, however, called into question the concept of collegial decisionmaking and issued a call for a more corporate model of management in which a college or university's chief executive officer "must resist academia's insatiable appetite for the kind of excessive consultation that can bring an institution to a standstill" (AGB, 1996, p. 6). Calls for a more efficient business-like approach to college and university governance were not new, but the statement reflected the increasing intensity and frequency of such proposals since the $1970 \mathrm{~s}$ (Gerber, 2010, p. 2).

Gerber (2010) asserted that by applying a model of business organization to institutions of higher learning, AGB was ignoring the fundamental assertion of the 1915 Declaration of Principles on Academic Freedom and Academic Tenure:

that faculty 'are not in any proper sense the employees' of college and university governing boards, but professionals who need both academic freedom and primacy in academic decision making to carry out their responsibilities to the public interest. (p. 22)

The following assertion highlights the changing sentiments about shared governance: "Many governing boards, faculty members, and chief executives believe that internal governance arrangements have become so cumbersome that timely decisions are difficult to make, and small factions often are able to impede the decision-making process" (AGB, 2001, p. 3).

Increase in non-faculty appointments. Rhoades (2005) suggests that another change affecting the concept of shared governance is the rise of non-faculty professionals on campus. Although these professionals have advanced degrees, technical bodies of knowledge, and professional associations, they are hired, evaluated, and fired by supervisors, not by peers, as faculty are. 
Rhoades (2005) asserts that "their increasing presence on campus shifts power to management," calling them managerial professionals to emphasize that administrators have more control over them than over faculty. These managerial professionals conduct some academic work and affect other such work, including teaching (p. 210). Rhoades (2005) explains:

Some participate with faculty in technology transfer to commercialize intellectual property. Others are involved, through teaching, professional development, and instructional assessment offices, in evaluating or developing the instructional activity of faculty members. They make decisions about and are involved in the production of software and multimedia packages used in the classroom. They promote the use of technology in instruction, conflating it with innovation and quality, and argue that faculty should change their instruction to become more interactive. With entrepreneurial universities comes a restructuring of professional work. But the rise of managerial professionals challenges not only the faculty's expertise - it also challenges the prevailing model of shared governance that sees two parties on campus, faculty and administrators, with the latter serving the trustees. (p. 210)

\section{Campus Influences on Shared Governance}

Campus differences. The great diversity of American colleges and universities and their hierarchical structure is widely recognized (Hammond, 2004; Kezar, 2009; Mortimer \& Sathre, 2007; Thelin, 2004; Tierney, 2004b), and there is accordingly an acknowledgement of diversity in their governance. The culture, structure, programs, personnel and technology of different institutions all influence participant expectations of how decisions are to be made and 
influence is to be allocated (Mortimer \& Sathre, 2007).

Birnbaum (1988) articulates it in this way:

The diversity of American higher education is reflected in significant differences in such critical matters as purpose, size, sponsorship, tradition, and values. Policies appropriate and fruitful for one type of institution may be harmful for another. Recommendations of policies that treat 'the faculty' or 'the administration' as alike in all institutions ignore the reality that the background and expectations of faculty and administrators at community colleges and at research universities, for example, might well produce very different approaches to governance. (p. 9)

Competing conceptions. While there is widespread support for shared governance as a laudable goal of higher education, there are substantial disagreements about what shared governance means and how it should be practiced (CHEPA, 2003, p. 9; Leach, 2008, p. 5) In a national survey of 3,800 individuals in over 750 four-year colleges and universities, CHEPA (2003) categorized the solicited definitions of shared governance in three different ways: 1) Fully collaborative decision-making characterizes a traditional approach that is sometimes referred to as a "collegial model" of governance in which the faculty and administration make decisions jointly, and consensus is the goal.

2) Consultative decision-making describes a more communicative model where the faculty's opinion and advice is sought, but where authority remains with the senior administration and the board of trustees. Although many individuals and groups are brought into the decision-making process, the model revolves around information sharing and discussion rather than joint decision making.

3) In the distributed decision-making model, decisions are made by discrete groups 
responsible for specific issues (p. 6). The understanding is that faculty have a right to make decisions in certain areas, and the administration and board in others. Mortimer and McConnell (1978) identified this approach as the separation of jurisdictions (p. 24).

Mortimer and Sathre (2007) explain the reasoning in terms of competence, concerns, cooperation, and cash, the four Cs of shared governance, as follows:

Authority and power need to be distributed in ways that ensure that those who have the relevant expertise/competence are in decisive roles. In addition, those who are concerned about the issue, those whose cooperation is necessary to implement it, and those whose cash is needed to fund it all have legitimate claims to participate. (p. 24)

Olson (2009) articulates the ongoing confusion about the nature of shared governance in higher education:

Shared governance is not a simple matter of committee consensus, or the faculty's engaging administrators to take on the dirty work, or any number of other common misconceptions. Shared governance is much more complex; it is a delicate balance between faculty and staff participation in planning and decision-making processes, on the one hand, and administrative accountability on the other. (para. 6)

In addition, organization scholars indicate that there remains confusion about who has the "right to govern (oversee) and the right to manage (take action)" (Hermalin, 2004, p. 41).

Lack of time. Among the most commonly cited barriers to shared governance is inadequate time. This is mentioned in regard to trustees, faculty, and administrators. Faculty work load, busy board meeting agendas, distance of trustees from campus, complexity of issues, 
and urgency of budget decisions are all factors (AGB, 2009b; Leach, 2008; Schwartz, Skinner, \& Bowen, 2009).

Lack of mutual understanding and respect. Pejorative views, role confusion, minimal interaction, and lack of information perpetuate stereotypes and make it harder to reach agreement on decisions, especially in a difficult economic environment. “ $\mathrm{M} u \mathrm{t} u$ a I $\mathrm{r}$ e s p e c t and understanding undergird successful com munication and decision-making in any relationship. Faculty and trustees generally share a com mon com m itment to the institutions they serve, and while they may not sharethe same priorities or agree on the means to achieve the m, they generally want what is best fortheir institutions" ( A G B, 2009 b, p. 11 ). D is puted turf-priorities and the means to achieve them-encompasses much of the decision-making terrain for institutional governance. As noted in the A G B study on governance ( 2009 a), faculty and trustees bring very different backgrounds, responsibilities, and skill sets to the table, with varying vie ws o n how to achievespecific outcom es. The divide between academic management and governance has been characterized by scholars as a tension between bureaucratic and professional authority (Etzioni, 1964), between planning and governance 
functions (Schuster, Smith, Corak \& Yamada, 1994), and between corporate and collegial models of decision making (Gumport,1993).

Trustees, as fiduciaries, bear ultim ate responsibility for ensuring sound financial decisions as well as sound acade mic quality, but most trustees have business backgrounds and few have ever worked in higher education. They are dependent upon the administration for leading and managing the institution and forthe expert professionaljudgment of faculty in regard to curricula, degree requirements, and peerreview. Trustees are generally more familiar with decision-making processes in a traditional business environ ment of m a nagerial authority. Frustrated by the pace of decision making in the acade my, they may expect the president to make decisions quickly with other a d m inistrators and "get results." Trustees usually learn about shared governance in their trustee roles ( A G B, 2009 b).

Faculty are accustomed to decision m a king by collegial bodies and often take on leadership roles in addition to their work 
responsibilities, receiving little recognition for the time involved. They are usually elected or nom inated by their peers, senior ad ministrators, or both for service on institution-wide com mittees. In many ways, like trustees, they volunteer their time for this governance work. Also like trustees, they learn on the job about institutional governance. Institutional governance is important work, often voluntary, and often unfamiliar to those who participate ( A G B , 2009 b).

Mortimer \& Sathre ( 2007 ) note that "the greatest gap in perceptions of the legitimacy of shared governance within colleges and universities is between faculty and trustees" ( $p$. 39 ). This is based on the faculty's beliefthat trustees have a limited role, if any, in acade mic affairs. Key to this is the belief that individual faculty mem bers require a high degree of professional autonomy to do their work. The primacy of individual autonom y also defines the profession collectively. It is the profession, not government leaders, trustees, or 
administrators, that sets the standards that define what is acceptable and unacceptable performance or what constitutes quality and what does not (Mortimer \& Sathre, 2007$)$.

In contrast, trustees may find such beliefs difficult to understand (Mortimer \& Sathre, 2007 ), perceiving this to be a lack of accountabilityor even freedom from responsibility. They state this com mon perception and tension as follows: "Those trustees with business experience tend to be uncomfortable with the lack of a bottom line" ( p. 39 ).

Further, governance policies and practices that aren't accessible, up-to-date, or understood create confusion about process and roles and hamper governance. Mortimer and Sathre (2007) suggest that "involvement of parties in the routine of program development, evaluation, and governance is where much of the conflict associated with the art of governance originates" (p. 55).

As noted throughout the literature, higher education is a complex industry. It suggests there is an enormous amount to learn in order to govern well:

The American college or university is a prototypic organized anarchy. It does not know what it is doing. Its goals are either vague or in dispute. Its technology is familiar but not understood. Its major participants wander in and out of the organization. These factors do not make a university a bad organization or a 
disorganized one; but they do make it a problem to describe, understand, and lead.

(Cohen \& March, 1974, p. 4)

Interaction is hampered by presidents who cannot or will not engage boards and faculty. The quality of interaction — communication, understanding, and work accomplished—is dependent upon the president. It takes the interest and support of all parties to make it work, but interaction in governance work can be thwarted by a president who does not see the value or is unable to overcome existing problems (AGB, 2009b; Mortimer \& Sathre, 2007).

In addition to some uncommitted presidents, there is a lack of interest among some trustees and faculty. This means there is neither the will to commit the needed time and energy, nor the best people attracted to serve in governance positions (AGB, 2009b).

\section{Benefits of Shared Governance}

The literature indicates that many critics of shared governance contend that a more hierarchical corporate model of management must replace the long-established collegial model of shared governance described in AAUP's 1966 Statement on Government of Colleges and Universities if our institutions of higher learning are to fulfill their mission and serve the public interest effectively (AGB, 2009b; Birnbaum, 2003; CHEPA, 2003).

However, Knapp and Siegel (2009) describe McGregor's 1960 theory of participative management as a foundation for understanding that organizations thrive best by trusting employees to apply their creativity and ingenuity in service of the whole enterprise, and to make important decisions close to the flow of work, including the selection and election of their bosses. Gerber (2001) also argues the following:

Maintaining and even strengthening substantial faculty participation in institutional governance is at least as necessary today as it was when the AAUP first established its standing Committee on College and University Governance back in 
1917. Now, as in the past, the practice of shared governance deserves to be supported not as a means of serving the particular interests of faculty, but rather because shared governance ultimately serves the needs of society. Without shared governance, our colleges and universities would be less likely to foster the unimpeded pursuit and dissemination of knowledge that are necessary for the healthy development of society; they would also be less likely to provide students with the broad liberal education they need to become informed citizens who can participate fully in our democracy. (para. 2)

Research on governance in higher education demonstrates how increasing stakeholder groups' input leads to several important outcomes: it (1) increases the complexity of analysis, (2) results in stronger decisions, (3) develops greater buy-in and trust, and (4) tends to improve morale (Birnbaum, 1992; Bensimon \& Neumann, 1993; Ferren \& Stanton, 2004: Kezar, Carducci \& Contreras-McGavin, 2006).

Also, there is evidence in the literature (CHEPA, 2003) to indicate that the concept of shared governance is highly valued, and an important part of the academy's values and identity. The national 2003 CHEPA survey demonstrated overwhelming support for shared governance across three constituent groups, the academic vice president, faculty senate leaders, and individual faculty members. A limitation of the study is the lack of inclusion of board members, who play an important role in shared governance and whose perception and understanding is critical to its implementation and success on campus.

The literaturesuggests that as de mands for greater accountability continue, especially

with respect to educational quality, boards will benefit from efforts to obtain faculty insight 
( $A G B, 2009 b ; G u m p o r t, 2001)$. Kezar, Lester, Carducci, Gallant \& M c G a vi n ( 2007 ) note," It is

easy to stereotype faculty leadership as merely a thorn in the side of administrators, but faculty leadership has a rich tradition that has helped create innovative and intellectually challenging environments" (p. 10).

While a comprehensive discussion of academic freedom is beyond the scope of this study, many authors affirm the concept that academic freedom is necessary for the proper functioning of colleges and universities, and that its practice relies upon shared governance. Gerber (2001) notes, “Too often, however, references to academic freedom in public discourse are formulaic or disingenuous and fail to take into account the full meaning of the concept and its close connection to faculty governance" (p. 6).

Haskell (1998) argues that "no justification for academic freedom can succeed unless it provides ample resources for justifying the autonomy and self-governance of the community" (p. 46). Further, he notes that for our institutions of higher education to fulfill their educational mission, teachers and researchers need protections that other citizens do not require. He argues that they need affirmative authority to shape the environment in which they carry out their responsibilities. Institutions of higher education, for example, do set constraints on how research is conducted, determine who is qualified to teach, and review and approve courses before they are included in the curriculum. When such determinations are made, Haskell underscores that concerns about academic freedom and governance become closely linked.

In this context, Haskell (1998) argues that when colleges and universities make decisions relating to teaching and research, it is essential that they make them on the basis of academic criteria and not on the basis of external political pressures or arbitrary administrative fiat. Academic freedom requires a governance system in which faculty expertise — often residing in 
an individual, but also expressed at times in a collective fashion-is the determining factor in institutional decisions affecting academic matters.

Consequently, the 1966 Statement on Government of Colleges and Universities, which remains the AAUP's principal policy document on the issue, premises its defense of shared governance on the assumption that faculty ought to exercise primary responsibility for such fundamental areas as curriculum, subject matter and methods of instruction, research, faculty status, and those aspects of student life which relate to the educational process, because the faculty — not students, administrators, or boards of trustees - have the greatest expertise in these matters (AAUP, 1966).

Further evidence supporting the benefits of shared governance ranges from case study exemplars to formalized, research-based evidence. The exemplars describing implementation of shared governance largely represent earlier work and provide a road map for designing governance structures in nursing practice (Anthony, 2004; Alvarado, Boblin-Cummings, \& Goddard, 2000; Evan, Aubry, Hawkins, Curley, \& Porter-O’Grady , 1995). However, these studies provide evidence of success with subjective appraisals of outcomes that include better relationships and team harmony, fewer conflicts, job satisfaction, communication, collaboration, professional growth, and lower turnover.

\section{The Conceptual Framework for Shared Governance}

The literature characterizes the American college as a uniquely complex organization (Leach, 2008; Morphew, 1999; Brown, 2000), and considering the great institutional diversity that exists from one institution to the next, it is generally recognized that it is not possible to prescribe a one-size-fits-all solution for shared governance (Tierney \& Minor, 2003; AGB, 2010a). Further, in his introduction to Organization and Governance in Higher Education, Brown (2000) notes: 
Organization and governance are the cornerstones of higher education as a field of study. The specifics of how colleges are governed vary from institution to institution. There are some campuses with presidents and some with chancellors. There are colleges with provost systems and others with deans. While no two institutional flow charts are identical, there are congruencies regarding the context, function, and performance of higher education administration. (p. xiii)

However, in spite of such diversity, there remains across the literature a consistent articulation of governance roles and elements of sound shared governance practices (AAUP, 1966; AFT, 2006; AGB, 2009a). For purposes of this study, a synthesis of three primary documents provides the context for these criteria: the American Association of University Professors 1966 Statement on Government of Colleges and Universities, the Association of Governing Board's 2010 Statement on Board Responsibility for Institutional Governance, and Keetjie Ramo's Assessing the Faculty's Role in Shared Governance (1997). Both AAUP and AGB provide seminal statements on shared governance. Ramo's publication has continued to be the foundation for understanding the AAUP standards on shared governance. Because this study will focus specifically on independent colleges, elements of governance specific to those types of institutions will be highlighted.

Birnbaum (1988) suggests that the AAUP's Joint Statement, as well as other normative statements on governance, "present positions of high principle that can be endorsed by many campus constituencies". The AAUP specifically states that it is "a call to mutual understanding regarding the government of colleges and universities," but also indicates that "it is not intended that the statement serve as a blueprint for governance on a specific campus" (p. 8).

In January of 2010, the Association of Governing Boards of Universities and Colleges published its Statement on Board Responsibility for Institutional Governance "intended to guide 
boards in the governance of colleges, universities, and systems, inform them of their roles and responsibilities, and clarify their collaborative relationships with presidents, administration, faculty, and others involved in the governance process" (AGB, 2010b, p. 6). This statement “encourages all governing boards and presidents to examine the clarity, coherence, and appropriateness of their institutions' governance structures, policies, and practices, and recommends a number of principles of good practice related to institutional governance" (2010b, p. 6).

While the specifics of each of these two documents are not meant to prescribe practices on individual campuses, they provide the parameters by which key stakeholders participate in the governance process, and highlight other necessary elements of good governance. The following sections articulate a synthesis of good governance standards as outlined by AAUP, with additional affirming references to the AGB. It should be noted in this context that shared governance incorporates a blending of the roles of management (action) and governance (oversight).

As noted in the literature, the parties to shared governance may be many, but for purposes of this study, the pertinent roles cited are limited to faculty, the president as key administrator, and the governing board. These are the "major governance partners who bear the burden for sharing and making governance work" (Mortimer \& Sathre, 2007, p. 113).

Institutional climate. Institutional climate has been defined as "the current common patterns of important dimensions of organizational life or its members' perceptions of and attitudes toward those dimensions" (Peterson \& Spencer, 1991, p. 143). In regard to academia more specifically, Spitzberg (1989) speaks of institutional climate as the presence or absence of "community" on campus. He argues that the breakdown of community on campuses—which he 
links to unresponsive governance structures, as well as an erosion of shared values-has adversely affected the quality of American higher education.

Ramo (1997) explains that climate "encompasses the quality of relationships among institutional constituents; working conditions; reward systems; and respect for the various appropriate roles of faculty, administration, and governing board" (p. 17). Ramo also notes that by definition, institutional climate is closely related to faculty morale. A study conducted under the auspices of the Council of Independent Colleges to examine faculty morale noted that of the four primary features held in common by the colleges that exemplified excellent faculty morale, the second was "strong, participatory leadership that provides direction and purpose while conveying to faculty the empowering conviction that the college is theirs" (Rice \& Austin, 1991, p. 20).

Ramo (1997) notes that while a cause-effect relationship was not inferred, climate can have a significant influence on the quality of governance, explaining as follows:

Shared governance, even when supported by institutional policies or tradition, can be undermined by a poor university climate. Conversely, policies and practices that undermine or ignore principles of shared governance can have an adverse effect on the institutional climate. Therefore, in assessing the health of shared governance, the institutional climate must be given consideration, as either an indicator of or contributor to the quality of that governance. (p. 18)

Institutional communication. Clear, open, ongoing and reciprocal communication among the various actors in the governance of an institution is a necessary criterion for good governance (Ramo, 1997). Most studies of organizational effectiveness cite the presence of 
structures and processes that foster open communication as an important criterion for judging the strength of an institution.

Taking into account that patterns of communication vary widely among institutions, the AAUP's Policy Documents and Reports, referred to as the Redbook, states that the interdependence of the governing board, faculty, administration, students and others requires "adequate communication among these components, and full opportunity for appropriate joint planning and effort” (AAUP, 2006, p. 136).

For this to be successfully accomplished, Ramo (1997) suggests that communication channels among an institution's components should be jointly established and maintained. These channels may include the circulation of memos and reports, the establishment of joint ad hoc committees, and maintenance of standing liaison committees, and provision for faculty membership or representation on governing boards.

In addition, in areas in which the faculty has a significant interest and responsibility, faculty representatives should have access to necessary information and adequate communication with administrators and others to enable them to make informed recommendations and decisions (Ramo, 1997).

The role of the president. As the chief executive officer of an institution of higher education, the president is measured largely by his or her capacity for institutional leadership. According to Hodson (2010):

University presidents and academic deans lead; it's what the institution and its many constituents expect of them. Presidents lead institutions through the mundane and the revolutionary. They inspire a shared vision and illuminate the path that leads to realization of that vision. (p. 39) 
In general, the president's work is to plan, to organize, to direct, and to represent, with the general support of board and faculty (AAUP, 2006). According to AAUP (2006):

The degree to which a president can provide vision for the institution, and can persuade others to see and work toward that vision, will often constitute the chief measure of the president's administration. The president's leadership role is supported by delegated authority from the board and faculty, and represents the institution to its many publics. (p. 138)

The president shares responsibility for administrative action and for the definition and attainment of goals, as well as for operating the communications system that links the components of the academic community. As the chief planning officer of an institution, the president is expected to innovate and to initiate. The president will utilize the judgments of the faculty but may also, in the interest of academic standards, seek outside evaluations by scholars of acknowledged competence (AAUP, 2006).

The president typically has ultimate managerial responsibility for nonacademic activities, and is largely responsible for the maintenance of existing institutional resources and the creation of new resources. The president is responsible for public understanding, and by the nature of the office is the institution's chief spokesperson (AGB, 2010b).

It is the duty of the president to see to it that the standards and procedures in operational use within the college or university conform to the policy established by the governing board and to the standards of sound academic practice. Pierce (2012) summarizes the board's typical expectations for the president: "It is standard practice for the board to charge the president with developing a vision for the future, a slate of evolving strategic priorities, and fundraising plans" 
(p. 67). In addition, the president is usually charged with ensuring that the institution adheres to standards of sound academic practice.

In matters of shared governance, the president is expected to serve as an advocate, and to ensure that the board understands the full range of faculty views and that the faculty likewise understands the decisions and views of the board and the administration (Pierce, 2012).

The role of the governing board. The responsibilities of boards of trustees hold an increasingly important place in the mixed system of governance of American institutions of higher education. "When the effectiveness of campus governance is in decline, trustees are held more closely to account, and their roles become more essential than in times of greater stability" (Ingram, 1994, p. 23). How boards, presidents, and faculty contribute to and engage one another in institutional governance speaks to the health of a particular college or university, as well as to the broader principles of autonomy, self-regulation, and accountability of higher education (Schwartz, Skinner \& Bowen, 2009).

Trustees of independent colleges and universities are surrogates of the general public. They are responsible for acting on behalf of their fellow citizens and institutional founders as their individual consciences and best judgment dictate (AGB, 2010b). Although they operate with much more freedom than public institution trustees, independent institution trustees have a clear obligation to act in the public interest, though they are not governed by sunshine laws or state policies (Pierce, 2012).

In addition, AAUP (2006) and AGB (2010b) documents indicate that the governing board has a special obligation to ensure that the history of the college or university shall serve as a prelude and inspiration to the future. The board helps relate the institution to its chief community: for example, the church-related college to be cognizant of its denominational 
affiliation, the community college to serve the educational needs of a defined population area or group, and the comprehensive university to accept the appropriate new challenges which are its concern at the several levels of higher education (AAUP, 2006).

The governing board of an institution of higher education in the United States operates, with few exceptions, as the final institutional authority. Private institutions are established by charters; public institutions are established by constitutional or statutory provisions. In private institutions the board is often self-perpetuating; in public colleges and universities the present membership of a board may be asked to suggest candidates for appointment (AGB, 2010b).

The governing board of an institution of higher education, while maintaining a general overview, entrusts the conduct of administration to the president, the administration, and the deans - and the conduct of teaching and research to the faculty. The board should undertake appropriate self-limitation (AGB, 2010b), which ensures that they will not be engaged in the management of daily operations.

One of the governing board's important tasks is to ensure the publication of codified statements that define the overall policies and procedures of the institution under its jurisdiction. The board plays a central role in relating the likely needs of the future to predictable resources; it has the responsibility for overseeing the endowment; it is responsible for obtaining needed capital and operating funds; and in the broadest sense of the term it has oversight of personnel policies. According to AAUP (2006), "In order to fulfill these duties, the board should be aided by, and may insist upon, the development of long-range planning by the administration and faculty" (p. 138). 
The role of the faculty. According to AAUP (2006), the faculty has primary responsibility for such fundamental areas as curriculum, subject matter and methods of instruction, research, faculty status, and those aspects of student life which relate to the educational process. The faculty sets the requirements for the degrees offered, determines when the requirements have been met, and authorizes the president and board to grant the degrees thus achieved.

Faculty status and related matters are primarily a faculty responsibility; this area includes appointments, reappointments, decisions not to reappoint, promotions, the granting of tenure, and dismissal. The primary responsibility of the faculty for such matters is based upon the fact that its judgment is central to general educational policy:

Furthermore, scholars in a particular field or activity have the chief competence for judging the work of their colleagues; in such competence it is implicit that responsibility exists for both adverse and favorable judgments. (AAUP, 2006, p. 138)

AAUP (2006) notes that the power of review or final decision lodged in the governing board or delegated by it to the president should be exercised adversely only in exceptional circumstances, and for reasons communicated to the faculty.

It is desirable that the faculty should, following such communication, have opportunity for further consideration and further transmittal of its views to the president or board. Budgets, personnel limitations, the time element, and the policies of other groups, bodies, and agencies having jurisdiction over the institution may set limits to realization of faculty advice. (AAUP, 2006, p. 139)

Based on AAUP statements, determinations in faculty personnel matters should first be by faculty action through established procedures and reviewed by the chief academic officers 
with the concurrence of the board. Specifically, "The governing board and president should, on questions of faculty status, as in other matters where the faculty has primary responsibility, concur with the faculty judgment except in rare instances and for compelling reasons which should be stated in detail" (2006, p. 139).

The chair or head of a department, as the chief representative of the department within an institution, should be selected either by departmental election or by appointment following consultation with members of the department and of related departments; appointments should normally be in conformity with department members' judgment. The chair or head should serve for a stated term but without prejudice to reelection or to reappointment by procedures that involve appropriate faculty consultation (AAUP, 2006).

AAUP (2006) suggests that, ideally, agencies for faculty participation in the government of the college or university should be established at each level where faculty responsibility is present. An agency should exist for the presentation of the views of the whole faculty. The structure and procedures for faculty participation should be designed, approved, and established by joint action of the components of the institution. Faculty representatives should be selected by the faculty according to procedures determined by the faculty. The agencies may consist of meetings of all faculty members of a department, school, college, division, or university system, or may take the form of faculty-elected executive committees in departments and schools and a faculty-elected senate or council for larger divisions or the institution as a whole.

The means of communication among the faculty, administration, and governing board now in use often include: (1) joint ad hoc committees; (2) circulation of memoranda and reports by board committees, the administration, and faculty committees; (3) standing liaison committees; (4) membership of faculty members on administrative bodies; and (5) membership 
of faculty members on governing boards. AAUP (2006) notes that the channels of communication should be clearly understood and observed throughout campus.

Joint decision making. The concept of shared governance suggests that the capacity to initiate policies and actions and the degree of decision-making authority shifts among the constituencies according to the responsibility of each for the matter at hand. Ramo (1997) notes that the sources of decision-making privilege among the various constituents will inevitably cause tension.

For the governing board, responsibility is based primarily on ascribed authority, "having less to do with vested interest and often less to do with expertise. The administration's decisionmaking privilege and responsibility is based primarily on formal authority and vested interest, and to greater or lesser degrees on expertise" (Ramo, 1997, p. 40).

In contrast, the faculty's decision-making authority is supported by little or no formal authority, depending on written policy and culture - but is strongly supported by expertise and vested interest, interwoven with academic freedom rights. Ramo (1997) notes, "These supports for faculty, while arguably the most morally legitimate, unfortunately carry far less weight than the power of ascribed authority" (p. 40).

The enactment of decision-making privilege for faculty in many settings depends upon the understanding and appreciation by governing boards and administrations of the need for such privilege. This is described by El-Khawas (1995) as follows:

Despite well-stated policy guidelines designed to buttress and give definition to shared decision-making roles, the continued viability of shared governance depends on the willingness of those who have financial and fiduciary responsibility for the institution to defer to the primacy of the faculty in matters of academic decision making" (p. 17). 
The Redbook (2006) outlines areas of primary responsibility of the trustees, the president, and the faculty, while also indicating that there are areas in which decision making is logically shared, with a greater proportion of responsibility sometimes going to one or the other of the participants. According to the AAUP's Statement on Government, the shaping and implementation of general education policy is guided by the institution's charter or law, as well as by the needs and aspirations of the institutional community and surrounding community.

Framing and executing long-range plans requires breadth and openness in the exchange of information and opinion among all constituents, and is considered a concern of the entire academic community. Other areas of joint responsibility include: the development of channels of communication, the search for a chief academic officer, decisions regarding existing and prospective physical resources, and developing the institutional budget. In addition, the Redbook refers to the search for a president or chancellor, the chief administrative officer, as "a joint effort of the most critical kind" (AAUP, 1995, p. 181).

Structural arrangements. AAUP (2006) policies and standards do not prescribe a particular structural arrangement for the actualization of shared governance. As Birnbaum (1988) points out, a "system of shared authority" that works for one institution won't necessarily work for another, and "governance is not in its essence a structure, but a shared idea about how to do higher education" (p. 39).

In general, the AAUP makes note of structural arrangements that support their policies. These include channels of communication among all the involved governance components of the institution, definitions of corporate and individual faculty status within the institution's government, role of the faculty in decisions relating to academic freedom and tenure, and appropriate procedures for the creation and operation of faculty committees (Ramo, 1997). 
The composition, origins, reporting lines, representativeness, functions, and leadership of committees vary widely within and among institutions. Ramo (1997) suggests that "the options chosen with regard to these variables should depend on the charge of the committee and its place in the governance structure" (p. 50).

Climate for Shared Governance. The preceding seven standards are meant to address the necessary conditions that exist when the climate for governance is sound (Ramo, 1997). These principles provide the basis for a survey instrument developed under AAUP auspices to gauge the climate for governance at institutions of higher education.

\section{Conclusion}

In its 2006 report entitled The Leadership Imperative, AGB (2006) describes the value of integral leadership as the foundation of shared governance, noting, "Leadership of this sort links the president, the faculty, and the board together in a well-functioning partnership purposefully devoted to a well-defined, broadly affirmed institutional vision” (p. 9). While such a partnership appears to be beneficial to institutions of higher education, controversies continue about whether shared governance is effective. 


\section{Chapter Three: Method}

The purpose of this study was to investigate how faculty, administrators, and staff perceived the climate for shared governance at 36 member institutions of the Appalachian College Association, based on standards for sound shared governance in higher education as outlined by the American Association of University Professors (AAUP).

In this chapter, the researcher describes and provides a rationale for the methodological approach for this study, including the research questions, the research design, the population and sampling procedure, the participants, the data collection and survey instrument, as well as data management and analysis. The strengths, limitations and delimitations of this study are also noted. 


\section{Research Questions}

This research study was guided by the following four research questions (RQs):

RQ1: What are faculty members' perceptions of the climate for shared governance at their institutions?

RQ2: What are administrators' perceptions of the climate for shared governance?

RQ3: What are staff members' perceptions of the climate for shared governance?

RQ4: What is the perceived climate for shared governance at ACA institutions?

\section{Research Design}

A quantitative method was used to conduct descriptive research for this study and to collect data "to test hypotheses or answer questions concerning the current status of the subject

of the study" (Gay, 1996, p. 249). According to Gay (1996), "a descriptive study determines and reports the way things are" (249).

Patton (2002) suggests that the following guiding questions should be asked in determining design decisions:

What are the purposes of the inquiry?

Who are the primary audiences for the findings?

What questions will guide the inquiry?

What data will answer or illuminate the inquiry questions?

What resources are available to support the inquiry?

What criteria will be used to judge the quality of the findings? (p. 13)

The researcher used a survey instrument developed by the AAUP to gauge the climate for shared governance, including a Likert scale to obtain perceptions about the climate. The author of the AAUP survey, Kietje Ramo (1997), notes that survey items are based on the following assumptions: 
According to AAUP's 1966 Statement on Government of Colleges and Universities, governance in higher education should result from cooperation and interdependence between and among the administration, governing board, faculty, and (to a lesser degree) other constituents. The Statement emphasizes that it is in the best interests of the institution for the president, governing board, and faculty to speak with a unified voice to outside agencies and publics whenever possible. A shared goal or spirit of collaboration on the part of the administration, governing board, and faculty is vital to healthy governance. (p. 7)

“A survey design provides a quantitative or numeric description of trends, attitudes, or opinions of a population by studying a sample of that population" (Creswell, 2003, p. 153). Patton (2002) explains that the results of survey research can provide inferences about the total population.

\section{Survey Instrument}

The seven governance standards as reflected in the conceptual framework are meant to address the necessary conditions that exist when the climate for governance is sound (Ramo, 1997). These principles provide the basis for a survey instrument (Appendix A) developed under AAUP auspices to assess the climate for governance at institutions of higher education. Based on a compendium authored by Keetjie Ramo in 1997 entitled Assessing Faculty's Role in Shared Governance: Implications of AAUP Standards, the survey was intended to gauge observable conditions at colleges and universities, not to gauge satisfaction (Ramo, 1997).

Including three demographic items added by the researcher, the 29-item survey was comprised of a series of 26 statements regarding the AAUP standards for shared governance, 
with two to five statements for each of the standards on which the climate for governance is

based. The following descriptions of the standards were not included on the survey instrument:

1. Institutional climate

2. Institutional communication

3. The board's role

4. The president's role

5. The faculty's role

6. Joint decision making

7. Structural arrangements.

These elements were based upon the relevant governance principles located throughout the AAUP Policy Documents and Reports and outlined in this study's conceptual framework section of the literature review.

In the compendium upon which the survey was developed, author Keetjie Ramo (1997) also considered pertinent governance literature and discussed the implications of the factors in the literature for the implementation of AAUP principles for sound governance.

Table 1 indicates the relationship of the survey items to the elements of sound governance as identified by AAUP, and on which the climate for governance is based.

Table 1

Relationship of Standards for Shared Governance to Research Questions

\begin{tabular}{|l|l|l|l|l|}
\hline Standard & $\mathrm{RQ1}$ & $\mathrm{RQ} 2$ & $\mathrm{RQ3}$ & $\mathrm{RQ} 4$ \\
\hline Institutional Climate & $4,5,11$ & $4,5,11$ & $4,5,11$ & $4,5,11$ \\
\hline $\begin{array}{l}\text { Institutional } \\
\text { Communication }\end{array}$ & 6,7 & 6,7 & 6,7 & 6,7 \\
\hline
\end{tabular}




\begin{tabular}{|l|l|l|l|l|}
\hline The Board's Role & $8,9,10$ & $8,9,10$ & $8,9,10$ & $8,9,10$ \\
\hline The President's Role & $12,13,14,15$ & $12,13,14,15$ & $12,13,14,15$ & $12,13,14,15$ \\
\hline The Faculty's Role & $16,17,18,29$ & $16,17,18,29$ & $16,17,18,29$ & $16,17,18,29$ \\
\hline Joint Decision Making & $\begin{array}{l}19,20,21,22, \\
23\end{array}$ & $\begin{array}{l}19,20,21,22, \\
23\end{array}$ & $\begin{array}{l}19,20,21,22, \\
23\end{array}$ & $\begin{array}{l}19,20,21,22, \\
23\end{array}$ \\
\hline Structural Arrangements & $\begin{array}{l}24,25,26,27, \\
28\end{array}$ & $\begin{array}{l}24,25,26,27, \\
28\end{array}$ & $\begin{array}{l}24,25,26,27, \\
28\end{array}$ & $\begin{array}{l}24,25,26,27, \\
28\end{array}$ \\
\hline
\end{tabular}

Demographic items. The first three survey items (\#1 through \#3) were added to the survey to gather demographic information about each respondent and to put them at ease in completing the survey (Dillman, Smyth, \& Christian, 2009; Iarossi, 2006). This optional, selfreported information included gender; tenure or non-tenure faculty status, cabinet-level administrator (serving on president's cabinet, regardless of title) or lower-level administrator (not on cabinet), or staff designation; and years in higher education. Respondents were able to selfidentify in more than one role.

Likert scale. Utilizing a five-point ordinal scale for survey items \#4 through \#29, the following levels of intensity dimensions were included: strongly agree, agree, disagree, strongly disagree, as well as "I don't know." "The Likert scale is a more refined tool that forces the respondent to give opinion on a series of statements..." (Hek \& Moule, 2006, p. 81). An optional opportunity for comment was provided on each of the survey items, allowing for clarifying information. 
According to Suskie (1996), the Likert scale is "easy to complete" and "efficient" (p. 33). In addition, the results of the survey can be easily converted into quantitative data. An online survey also provided additional convenience to the participants and was cost efficient.

Of the 26 Likert items that were part of the analyses (Items \#4 to \#29), 23 were positively phrased, while 3 (Items \#9, \#13, and \#26) were negatively phrased. Utilizing a mixture of positively and negatively phrased items "helps to minimize acquiescence bias, positional bias, and response bias" (Field, 2009, p. 675; Sapsford, 2007).

Suskie (2004) explains, adding opposing views "will help to prevent the yeasayer/naysayer effect, in which some people with generally positive feelings toward your topic may check all the 'strongly agree' responses without reading each item and those with generally negative feelings may do the opposite" (p. 228).

\section{Population and Sampling}

Population of interest. Shared governance has historically been a hallmark of small, independent institutions of higher education in the United States, and the Appalachian College Association (ACA) provides an opportunity to conduct convenience sampling of an appropriate population for this study - faculty, administrators, and staff who participate in shared governance on each ACA campus.

The ACA is a non-profit consortium of 36 independent, four-year, liberal arts colleges and universities spread across the central Appalachian Mountains in Kentucky, North Carolina, Tennessee, Virginia, and West Virginia. Collectively these higher education institutions serve approximately 42,500 students. The Association helps develop and share ideas, information, 
programs and resources to achieve its goals, which include promoting cooperation and

collaboration among its member institutions to serve the people of Appalachia through higher

education and related services. The ACA institutions are listed below by state:

\section{Kentucky}

Alice Lloyd College

Berea College

Campbellsville University

Kentucky Christian University

Lindsey Wilson College

Pikeville College

Union College

University of the Cumberlands

\section{North Carolina}

Brevard College

Lees-McRae College

Lenoir-Rhyne University

Mars Hill College

Montreat College

Warren Wilson College

\section{Tennessee}

Bryan College

Carson-Newman College

Johnson Bible College

King College

Lee University

Lincoln Memorial University

Maryville College

Milligan College

Tennessee Wesleyan College

Tusculum College

University of the South

\section{Virginia}

Bluefield College

Emory \& Henry College

Ferrum College

Virginia Intermont College

\section{West Virginia}

Alderson-Broaddus College

Bethany College

Davis \& Elkins College 
Ohio Valley University

University of Charleston

West Virginia Wesleyan College

Wheeling Jesuit University

After several conversations and e-mail communications, the researcher obtained approval from the ACA president to conduct the study through the Association (Appendix B). The president of the ACA also agreed to introduce the study to each campus in an e-mail to presidents and academic vice presidents and encourage them to participate.

Sampling. Because the population for this study was small $(\mathrm{N}=480)$, it was convenient to invite the entire population to participate. After IRB approval to conduct the study was received (Appendix C) on September 18, 2013, the ACA president introduced the study with a letter to presidents and vice presidents for academic affairs at all 36 ACA schools and encouraged them to participate (Appendix D) on November 6, 2013. The researcher then asked all ACA institutions to participate in the study and sought approval via an e-mail to those same presidents and vice presidents of academic affairs (Appendix E) on November 14, 2013. A follow-up reminder was e-mailed to them on November 18, 2013 (Appendix F).

Because this group of respondents tends to have very busy professional careers (Eckel \& Kezar, 2011), a low response rate was expected. The e-mail also included the request for a campus liaison from whom a list of faculty, staff, and administrators who have a role in their campus decision-making process could be obtained, in keeping with the recommendation by the AAUP for use of the survey.

\section{Survey Administration Procedure and Timeline}

E-mail addresses. In order to electronically seek approval to conduct the study on ACA campuses, e-mail addresses of presidents and vice presidents for academic affairs were obtained from the Appalachian College Association, which maintains updated distribution lists for their 
member institutions. The researcher was encouraged to use this as the primary method of communication throughout the study, given the nature of the Association and their traditional reliance on e-mail.

After approvals, campus liaisons identified by presidents or vice presidents for academic affairs provided names, e-mail addresses, and titles of potential survey participants based on their roles in campus governance.

Contacts with participants. Presidents at 12 out of 36 ACA schools gave approval for institutional participation and forwarded names and e-mails of campus liaisons who would provide a list of potential participants to the researcher. Two institutions required IRB approval at their own campus.

Campus liaisons provided lists of e-mails, names, and titles of 480 potential participants. Lists from each institution varied widely from 8 to 122 names. As lists were received from campus liaisons, they were reviewed by the researcher for appropriate representation of faculty, staff, and administrators based on their roles and titles.

In keeping with AAUP's recommendation, participants included faculty, administrators, and staff members at ACA institutions who were deemed to have the best understanding of the governance process on their respective campuses based on their roles and engagement in decision making. The ACA provides a natural grouping of constituents who regularly receive and respond to e-mail communications.

The researcher began data collection late in the fall semester of 2013. Beginning on December 2, 2013, e-mail invitations with the survey link (Appendix G) were sent to potential participants on each campus on varying dates, depending on receipt of presidential approval and upon receipt of the list from the campus liaison. One- and two-week reminders were sent to each 
campus. There was no attempt to track responses by individual participating institutions. The survey link was closed on February 10, 2014.

The following Table 2 reflects the research project timeline.

Table 2

Research Project Timeline

Date Action

4/9/12 Research proposal approved by committee (prospectus defense meeting)

3/19/13 Research protocol submitted to IRB for human subjects approval

9/18/13 Research protocol acknowledged and approved by IRB

11/6/13 E-mail introduction by ACA president to presidents and vice presidents

11/14/13 E-mail invitation mailed to presidents and vice presidents for academic affairs

11/18/13 E-mail reminder

12/2/13- E-mail invitations (with survey link) e-mailed to faculty, administrators, and staff

$2 / 3 / 13$

$2 / 10 / 13$ with one- and two-week reminders

Survey closed

\section{Data Analysis}

Once the survey was closed, the researcher used statistical analysis tools and descriptive statistics through SurveyMonkey to analyze the data from the survey instrument to address the four research questions. Because the survey items were based upon the seven standards of shared governance as outlined by AAUP as a measure of the climate for governance, every standard was analyzed as part of each research question.

\section{Limitations, Delimitations and Strengths}

"A quantitative approach makes it possible to measure the reactions of a great many people to a limited set of questions, thus facilitating comparison and statistical aggregation of the data. This gives a broad, generalizable set of findings presented succinctly and parsimoniously" 
(Patton, 2002, p. 14). The results of this study provide concise, quantitative, numerical data, with results relatively independent of the researcher.

Creswell (2003) suggests that researchers "use delimitations to narrow the scope of a study" (p. 36). This study confined itself to surveying faculty, administrators, and staff at member institutions of the Appalachian College Association. It produced data about a relatively small number of institutions.

1. Limitations of time and resources may affect the data gathering and analysis.

2. This study was limited to member institutions of the Appalachian College Association. Therefore, the respondents of this study may not represent faculty, administrators, and staff at other institutions of higher education.

3. Climate for shared governance will be measured by self-reporting perceptions by the participants; therefore the study is limited by the accuracy of the respondents' selfperceptions.

4. This study was conducted during the fall 2013 semester and may not represent past or future faculty, administrators, and staff at ACA institutions.

5. There was no attempt to include board members in this study, though they are considered key participants in shared governance.

\section{Protection of Human Subjects}

Every effort was made to protect human subjects involved in this study. Written permission was obtained from the West Virginia University Institutional Research Board (IRB) for the Protection of Human Subjects, from the Appalachian College Association, and from individual institutions. Implied consent was obtained through the invitation and survey link sent to participants via SurveyMonkey. 
The Internet survey that was used for this study enabled the respondents to remain anonymous, and e-mails with the survey link were sent via "blind carbon" to ensure anonymity of the recipients. Participants were notified of the voluntary nature of their participation, and were expressly told that they could skip items or exit the survey at any time.

The information that was requested from the respondents was unidentifiable, except for participants' open-ended comments, which were screened and edited by the researcher before inclusion in the study results in order to ensure confidentiality and anonymity of the participants and their institutions.

In addition, steps were taken through the survey settings in SurveyMonkey to further ensure anonymity. The survey was configured not to collect Internet Protocol (IP) addresses when a respondent completed the survey.

The list of participating institutions was maintained on a secure server, ensuring confidentiality. Study results will be destroyed after three years.

\section{Background of the Researcher}

The researcher's educational background includes an undergraduate degree in English composition and a master's degree in higher education administration. As the study concludes, the researcher is a doctoral student in the higher education administration program at West Virginia University, and currently serves in an administrative position at a law school at an independent Catholic University of approximately 7,000 students.

With over 25 years of experience in higher education, the researcher began her career teaching in a federally-funded job training program at a small, independent institution, and currently serves as chief fundraiser for a law school, after two years of experience as a vice 
president for enrollment management.

For the past 15 years, the researcher has had significant engagement with various governing boards while serving as VP for Advancement at two different independent colleges, and has served on numerous committees comprised of faculty, staff, and administrative colleagues.

\section{Chapter Four: Results}

\section{Introduction}

This dissertation study examined faculty, administrative, and staff perceptions of the climate for shared governance at Appalachian College Association member institutions, based on standards for shared governance outlined by the American Association of University Professors.

The results of this investigation are reported in accordance with the four research questions. Research Question 1 concerned the perceptions of faculty members. Research Question 2 addressed administrators' perceptions. Question 3 examined staff members' 
perceptions. Question 4 explored comprehensive perceptions of shared governance in the Appalachian College Association.

\section{Survey Responses}

At the time of closing the survey in SurveyMonkey on February 10, 2014, a total of 176 survey responses had been collected. Approval for participation in the study was received from presidents at 12 of the $36 \mathrm{ACA}$ institutions, representing $33.33 \%$. This included institutions from the following states: Kentucky, North Carolina, Tennessee, Virginia, and West Virginia, which represented all of the states included in the ACA.

The population for this study was 480 faculty, administrators, and staff members at the 12 participating ACA institutions. The final data set included 176 survey responses, which represented a response rate of $36.66 \%$.

\section{Demographic Information of Study Participants}

Participants were asked three demographic questions: gender, role and status, and years in higher education. The 175 respondents to the gender item were divided between male $(53.71 \%)$ and female $(46.29 \%)$.

As shown in Table 3, a total of 162 respondents reported their position and status as faculty, staff, or administrator, with the option of indicating more than one role. There were 196 responses. The majority of respondents were administrators (26.53\%) and cabinetlevel administrators (18.88\%), which together totaled $45.41 \%$. Faculty respondents, including tenured $(22.95 \%)$ and non-tenured $(17.86 \%)$ represented $40.81 \%$. Staff members represented the fewest respondents at $13.78 \%$.

Table 3

Respondents' Type of Position and Status 
Tenured Faculty Member

Non-tenured Faculty Member

Staff Member

Cabinet-level Administrator

Administrator

Total
45

35

27

37

52

196
22.95

17.86

13.78

18.88

26.53

$100 \%$

As shown in Table 4, of the 174 respondents who indicated their years in higher education, the highest percentage (17.24\%) served from 21-25 years.

Table 4

Respondents' Years in Higher Education

$n$

Less than 1 year

$1-5$ years

6-10 years

11-15 years
2

26

28

28
$\%$

1.15

14.94

16.09

16.09 
$16-20$ years

21-25 years

26-30 years

More than 30 years

Total
27

30

17

16

174
15.52

17.24

9.77

9.20

$100 \%$

\section{Findings from the Research Questions}

The following section addresses each research question with descriptive statistics for each of the seven standards for shared governance included in the survey, and as outlined in Table 1. For each survey item, the frequencies (N) and percentages (\%) are calculated.

Research Question \#1. What are faculty members' perceptions of the climate for shared governance at their institutions?

There were a total of 80 faculty respondents in this study. This included both tenured (45) and non-tenured (35) faculty members.

Institutional climate. There were three survey items on institutional climate at ACA institutions--survey items \#4, \#5, and \#11 as reflected in Table 5.

Survey item \#4 addressed whether there was a culture of collegiality and respect on their campus. There was similar response among faculty, with $62.22 \%$ of tenured faculty and $62.86 \%$ of non-tenured faculty agreeing with the statement that "there is a culture of collegiality and respect on our campus." Tenured faculty members were more likely to strongly agree with the statement $(31.11 \%)$ compared to non-tenured faculty $(17.14 \%)$.

In response to the statement in survey item \#5 that campus negotiations were conducted in good faith and trust, $71.11 \%$ of tenured faculty agreed or strongly agreed, compared to $57.15 \%$ of non-tenured faculty, who also disagreed or strongly disagreed at a rate of $37.14 \%$. 
In response to the statement in survey item \#11 noting "the Board respects and supports the faculty's traditional role in institutional governance," a majority (72.09\%) of tenured faculty agreed or strongly agreed compared to $45.45 \%$ of non-tenured faculty. In addition, $36.36 \%$ of the non-tenured faculty responded "I don't know" compared to $6.98 \%$ of the tenured faculty. Table 5

Faculty Perceptions

Item Governance Standard

\begin{tabular}{|c|c|c|c|c|c|}
\hline & \multicolumn{5}{|c|}{ Levels of Agreement } \\
\hline$n$ & $\begin{array}{c}\text { Strongly } \\
\text { Agree }\end{array}$ & Agree & Disagree & $\begin{array}{l}\text { Strongly } \\
\text { Disagree }\end{array}$ & $\begin{array}{l}\text { I don't } \\
\text { Know }\end{array}$ \\
\hline & $\begin{array}{l}n \\
\end{array}$ & $n \quad \%$ & $n \quad \%$ & $n \quad \%$ & $n \quad \%$ \\
\hline
\end{tabular}

Institutional Climate

SI 4 Culture of collegiality and respect

Tenured Faculty

Non-tenured Faculty

\section{5}

35

$\begin{array}{cccccc}45 & 14 & 31.11 & 28 & 62.22 & 3 \\ 35 & 6 & 17.14 & 22 & 62.86 & 5\end{array}$

$\begin{array}{rr}6.67 & 0 \\ 14.29 & 1\end{array}$

$\begin{array}{llll}14.29 & 1 & 2.86 & 1\end{array}$

SI 5 Negotiations in good faith and trust

Tenured Faculty

Non-tenured Faculty

$\begin{array}{rrrrrlclrll}45 & 2 & 4.44 & 30 & 66.67 & 9 & 20 & 3 & 6.67 & 1 & 2.22 \\ 35 & 5 & 14.29 & 15 & 42.86 & 9 & 25.71 & 4 & 11.43 & 2 & 5.71\end{array}$

SI 11Board supports faculty's role

Tenured Faculty

Non-tenured Faculty

$\begin{array}{rrrrrrrrrcc}43 & 8 & 18.60 & 23 & 53.49 & 7 & 16.2 & 2 & 4.65 & 3 & 6.98 \\ 33 & 3 & 9.09 & 12 & 36.36 & 5 & 15.15 & 1 & 3.03 & 12 & 36.36\end{array}$

\section{Institutional communication. On the first of two survey items addressing}

communication, and reflected in Table 6 as item 6 , slightly more than $86 \%$ of tenured faculty agreed or strongly agreed that there was a process for consultation with faculty leadership, as did a majority of non-tenured faculty $(68.57 \%)$. However, $11.43 \%$ of non-tenured faculty indicated they did not know if there was a process for consultation, compared to $0 \%$ of the tenured faculty.

In response to the statement in item 7 that "the faculty as a whole has timely access to information necessary for faculty members to give input into governance processes," a majority 
of tenured faculty strongly agreed or agreed (75.91\%). Non-tenured faculty were more likely to indicate they disagreed or strongly disagreed (48.57\%) than any other choice.

\section{Table 6}

Faculty Perceptions

Item Governance Standard

\begin{tabular}{|c|c|c|c|c|c|}
\hline \multicolumn{6}{|c|}{ Levels of Agreement } \\
\hline & Strongly & & & Strongly & I don't \\
\hline$n$ & Agree & Agree & Disagree & Disagree & Know \\
\hline & $n \quad \%$ & $n \quad \%$ & $n \quad \%$ & $n \quad \%$ & $n \quad \%$ \\
\hline
\end{tabular}

Communication

SI 6 Process for Consultation with Faculty

Tenured Faculty

$\begin{array}{lllllllllll}44 & 9 & 20.45 & 29 & 65.91 & 5 & 11.36 & 1 & 2.27 & 0 & 0\end{array}$

Non-tenured Faculty

$\begin{array}{lllllllllll}35 & 7 & 20.00 & 17 & 48.57 & 5 & 14.29 & 2 & 5.71 & 4 & 11.43\end{array}$

SI 7 Whole faculty has access to information

$\begin{array}{lrrrrrrrrrll}\text { Tenured Faculty } & 44 & 8 & 18.18 & 21 & 47.73 & 12 & 27.27 & 3 & 6.82 & 0 & 0 \\ \text { Non-tenured Faculty } & 35 & 2 & 5.71 & 14 & 40.00 & 11 & 31.43 & 6 & 17.14 & 2 & 5.71\end{array}$

The board's role. Three survey items (\#8, \#9, and \#10), as reflected in Table 7, addressed the role of the governing board.

As indicated in item \#8, while more than half of the tenured faculty (57.78\%) agreed or strongly agreed that board members had appropriate education and experience, $40 \%$ of the nontenured faculty indicated they did not know board qualifications.

Survey item \#9 was negatively worded: Board members are not involved in the day-today operations of the institution. While a majority of faculty, both tenured (86.66\%) and nontenured (54.28\%), indicated they strongly agreed or agreed with the statement, non-tenured were more likely to indicate they did not know the board's involvement (34.29\%). 
As indicated by item \#10, a majority of tenured faculty (63.64\%) and almost threequarters of non-tenured faculty $(71.43 \%)$ indicated they did not know whether governing board members were informed on governance issues.

Table 7

Faculty Perceptions

Item Governance Standard

Board's Role

Levels of Agreement

\begin{tabular}{|c|c|c|c|c|c|}
\hline$n$ & $\begin{array}{c}\text { Strongly } \\
\text { Agree }\end{array}$ & Agree & Disagree & $\begin{array}{l}\text { Strongly } \\
\text { Disagree }\end{array}$ & $\begin{array}{l}\text { I don't } \\
\text { Know }\end{array}$ \\
\hline & $\%$ & $\%$ & $n \quad \%$ & $n \quad \%$ & $n \quad \%$ \\
\hline
\end{tabular}

SI 8 Has appropriate qualifications

Tenured Faculty

Non-tenured Faculty

$\begin{array}{lllllllllll}45 & 5 & 11.11 & 21 & 46.67 & 6 & 13.33 & 2 & 4.44 & 11 & 24.44 \\ 35 & 6 & 17.14 & 8 & 22.86 & 5 & 14.29 & 2 & 5.71 & 14 & 40.00\end{array}$

SI 9 Is not involved in daily operations

$\begin{array}{lccccccccccc}\text { Tenured Faculty } & 45 & 15 & 33.33 & 24 & 53.33 & 3 & 6.67 & 0 & 0 & 3 & 6.67 \\ \text { Non-tenured Faculty } & 35 & 10 & 28.57 & 9 & 25.71 & 3 & 8.57 & 1 & 2.86 & 12 & 34.29\end{array}$

SI10 Is informed on governance issues

$\begin{array}{lccccccccccc}\text { Tenured Faculty } & 44 & 2 & 4.55 & 6 & 13.64 & 4 & 9.09 & 4 & 9.09 & 26 & 63.64 \\ \text { Non-tenured Faculty } & 35 & 1 & 2.86 & 2 & 5.71 & 6 & 17.14 & 1 & 2.86 & 25 & 71.43\end{array}$

The president's role. Survey items \#12, \#13, \#14, and \#15 addressed the role of the president in the governance process, as reflected in Table 8.

As indicated by item \#12, the majority of tenured (93.02\%) and non-tenured $(80.42 \%)$ faculty agreed or strongly agreed that their president had adequate academic and administrative credentials to serve as the chief executive officer.

As reflected on item \#13, more than three-quarters of tenured $(83.72 \%)$ and over half of the non-tenured faculty $(58.83 \%)$ strongly agreed or agreed that the president rarely overturned 
faculty decisions and recommendations in areas in which faculty has primary responsibility, such as curriculum, tenure, and faculty promotion. However, the non-tenured faculty were more likely to indicate they did not know $(23.53 \%)$ compared to tenured faculty $(2.33 \%)$.

In response to the statement in item \#14 that "The president seeks faculty input on matters that are his or her primary responsibility (such as budgeting) in which the faculty has an appropriate interest but not primary responsibility," almost three-quarters of tenured faculty $(71.43 \%)$ agreed or strongly agreed, and $57.57 \%$ of non-tenured faculty agreed or strongly agreed. Almost $40 \%$ of the non-tenured faculty disagreed or strongly disagreed with the statement.

As indicated on item \#15, 48.84\% of the tenured faculty and $35.29 \%$ of the non-tenured faculty agreed or strongly agreed that the president effectively advocated shared governance to the governing board. Almost $40 \%$ of the tenured faculty indicated "I don't know," while $50 \%$ of the non-tenured faculty indicated "I don't know."

Table 8

Faculty Perceptions

Item Governance Standard

\begin{tabular}{|c|c|c|c|c|c|}
\hline$n$ & $\begin{array}{c}\text { Strongly } \\
\text { Agree }\end{array}$ & Agree & Disagree & $\begin{array}{l}\text { Strongly } \\
\text { Disagree }\end{array}$ & $\begin{array}{l}\text { I don't } \\
\text { Know }\end{array}$ \\
\hline & $n \quad \%$ & $n \quad \%$ & $n \quad \%$ & $n \quad \%$ & $\begin{array}{l}n \\
n\end{array}$ \\
\hline
\end{tabular}

President's Role

SI 12 Has appropriate credentials Tenured Faculty Non-tenured Faculty

$\begin{array}{lllllllllll}43 & 18 & 41.86 & 22 & 51.16 & 0 & 0 & 1 & 2.33 & 2 & 4.65\end{array}$

$\begin{array}{lllllllllll}34 & 14 & 41.18 & 13 & 38.24 & 3 & 8.82 & 2 & 5.88 & 2 & 5.88\end{array}$


SI 13 Rarely overturns faculty positions

Tenured Faculty

Non-tenured Faculty

SI 14 Seeks faculty input

Tenured Faculty

Non-tenured Faculty

SI 15 Advocates shared governance

Tenured Faculty

Non-tenured Faculty

$\begin{array}{llll}43 & 15 & 34.88 & 21\end{array}$

$\begin{array}{llll}34 & 8 & 17.65 & 14\end{array}$

48.84

41.78

$\begin{array}{llll}42 & 7 & 16.67 & 23\end{array}$

$\begin{array}{llll}33 & 5 & 15.15 & 14\end{array}$

54.76

42.42

4

$\begin{array}{ccccccccccc}43 & 7 & 16.28 & 14 & 32.56 & 2 & 4.65 & 3 & 6.98 & 17 & 39.33 \\ 34 & 3 & 8.82 & 9 & 26.47 & 3 & 8.82 & 2 & 5.88 & 17 & 50.00\end{array}$

The faculty's role. Four survey items (\#16, \#17, \#18, and \#29), reflected in Table 9, addressed the role of the faculty at Appalachian College Association institutions.

Slightly more non-tenured faculty (52.94\%) agreed with the statement in item \#16 that "the faculty is afforded an appropriate degree of autonomy with regard to its area of primary responsibility" than the tenured faculty (50\%). However, $17.65 \%$ of the non-tenured faculty strongly disagreed, compared to $0 \%$ of the tenured faculty.

Non-tenured faculty (23.53\%) were more than twice as likely to disagree with the statement in item \#17 that "the faculty appropriately exercises its capacity for both adverse and positive decisions in faculty personnel matters" than the tenured faculty (11.63\%).

A majority of faculty, both tenured (64.28\%) and non-tenured (58.83\%) indicated they disagreed or strongly disagreed with the statement in item \#18 that "resources for faculty development, reward structures, and workloads support the development of faculty expertise in shared governance."

As indicated on item \#29, while a majority of tenured faculty $(64.29 \%)$ indicated they agreed or strongly agreed with the statement that "the faculty as a whole has an opportunity to meet and comment on 'short-listed' academic administrative candidates before hiring decisions 
are made," over $40 \%$ of the non-tenured faculty $(42.42 \%)$ disagreed or strongly disagreed, while

$21.21 \%$ indicated 'I don't know."

Table 9

Faculty Perceptions

\begin{tabular}{|c|c|c|c|c|c|c|c|c|c|c|c|}
\hline \multirow{4}{*}{ Governance Standard } & \multicolumn{11}{|c|}{ Levels of Agreement } \\
\hline & \multirow{2}{*}{\multicolumn{3}{|c|}{$\begin{array}{c}\text { Strongly } \\
\text { Agree }\end{array}$}} & \multirow{2}{*}{\multicolumn{2}{|c|}{ Agree }} & \multirow{2}{*}{\multicolumn{2}{|c|}{ Disagree }} & \multirow{2}{*}{\multicolumn{2}{|c|}{$\begin{array}{l}\text { Strongly } \\
\text { Disagree }\end{array}$}} & \multirow{2}{*}{\multicolumn{2}{|c|}{$\begin{array}{l}\text { I don't } \\
\text { Know }\end{array}$}} \\
\hline & & & & & & & & & & & \\
\hline & & $n$ & $\%$ & $n$ & $\%$ & $n$ & $\%$ & $n$ & $\%$ & $n$ & $\%$ \\
\hline \multicolumn{12}{|l|}{ Faculty's Role } \\
\hline \multicolumn{12}{|c|}{ SI 16 Autonomy for primary responsibilities } \\
\hline Tenured Faculty & 42 & 14 & 33.33 & 21 & 50.00 & 6 & 14.29 & 0 & 0 & 1 & 2.38 \\
\hline Non-tenured Faculty & 34 & 4 & 11.76 & 18 & 52.94 & 6 & 17.65 & 6 & 17.65 & 0 & 0 \\
\hline \multicolumn{12}{|c|}{ SI 17 Exercises capacity for decisions } \\
\hline Tenured Faculty & 43 & 9 & 20.93 & 22 & 51.16 & 5 & 11.63 & 1 & 2.33 & 6 & 13.95 \\
\hline Non-tenured Faculty & 34 & 5 & 14.71 & 12 & 35.29 & 6 & 23.53 & 3 & 8.82 & 6 & 17.65 \\
\hline \multicolumn{12}{|c|}{ SI 18 Resources support expertise } \\
\hline Tenured Faculty & 42 & 1 & 2.38 & 10 & 23.81 & 19 & 45.24 & 5 & 19.05 & 4 & 9.52 \\
\hline Non-tenured Faculty & 34 & 2 & 5.88 & 8 & 23.53 & 15 & 44.12 & 5 & 14.71 & 4 & 11.76 \\
\hline \multicolumn{12}{|c|}{ SI 29 Input on academic candidates } \\
\hline Tenured Faculty & 42 & 6 & 19.05 & 19 & 45.25 & 8 & 19.05 & 7 & 16.67 & 0 & 0 \\
\hline Non-tenured Faculty & 33 & 1 & 3.03 & 11 & 33.33 & 10 & 30.30 & 4 & 12.12 & 7 & 21.21 \\
\hline
\end{tabular}

Joint decision making. Five items addressed joint decision making (\#19, \#20, \#21, \#22, and \#23) and are reflected in Table 10.

While the majority of tenured faculty $(62.79 \%)$ indicated they agreed or strongly agreed with the statement in item \#19 that there is joint responsibility for decision making in the area of long-range planning, almost 50\% (48.48\%) of the non-tenured faculty disagreed or strongly disagreed. 
As reflected on item \#20, a majority of both tenured (56.41\%) and non-tenured $(54.54 \%)$ faculty disagreed or strongly disagreed with the statement that "there is joint responsibility for decision making regarding existing or prospective physical resources."

In response to the statement in item \#21 that "there is joint responsibility for decision making in institutional budgeting," tenured faculty were closely split between responses of strongly agree and agree (50\%) and disagree or strongly disagree (47.62\%), while non-tenured faculty tended to disagree or strongly disagree $(66.66 \%)$.

As indicated on item \#22, almost three-quarters of the tenured faculty (74.42\%) agreed or strongly agreed that "there is joint responsibility for decision making in the selection of a new president," while more than half $(57.58 \%)$ of non-tenured faculty indicated "I don't know."

As indicated on item \#23, while the majority of tenured $(95.35 \%)$ and non-tenured $(62.50 \%)$ faculty agreed or strongly agreed with the statement that there is "joint responsibility for decision making in faculty selection and promotion and the granting of tenure," $18.75 \%$ of the non-tenured faculty indicated "I don't know."

Table 10

Faculty Perceptions

\begin{tabular}{|c|c|c|c|c|c|c|c|c|c|c|c|c|}
\hline \multirow{4}{*}{ Item } & \multirow{4}{*}{ Governance Standard } & \multicolumn{11}{|c|}{ Levels of Agreement } \\
\hline & & \multirow{3}{*}{$n$} & \multirow{2}{*}{\multicolumn{2}{|c|}{$\begin{array}{c}\text { Strongly } \\
\text { Agree }\end{array}$}} & \multirow{2}{*}{\multicolumn{2}{|c|}{ Agree }} & \multirow{2}{*}{\multicolumn{2}{|c|}{ Disagree }} & \multicolumn{2}{|c|}{ Strongly } & \multirow{2}{*}{\multicolumn{2}{|c|}{$\begin{array}{l}\text { I don't } \\
\text { Know }\end{array}$}} \\
\hline & & & & & & & & & & agree & & \\
\hline & & & $n$ & $\%$ & $n$ & $\%$ & $n$ & $\%$ & $n$ & $\%$ & $n$ & $\%$ \\
\hline \multicolumn{13}{|c|}{ Joint Decision Making } \\
\hline \multicolumn{13}{|c|}{ SI 19 Long-range planning } \\
\hline & Tenured Faculty & 43 & 5 & 11.63 & 22 & 51.16 & 6 & 18.60 & 5 & 11.63 & 3 & 6.98 \\
\hline & Non-tenured Faculty & 33 & 3 & 9.09 & 10 & 30.30 & 8 & 24.24 & 8 & 24.24 & 4 & 12.12 \\
\hline \multicolumn{13}{|c|}{ SI 20 Physical resources } \\
\hline & Tenured Faculty & 39 & 2 & 5.13 & 14 & 35.90 & 16 & 41.03 & 6 & 15.38 & 1 & 2.56 \\
\hline
\end{tabular}


$\begin{array}{llllllllllll}\text { Non-tenured Faculty } & 33 & 0 & 0 & 10 & 30.30 & 11 & 33.33 & 7 & 21.21 & 5 & 15.15\end{array}$

SI 21 Institutional budgeting

$\begin{array}{lccccccccccc}\text { Tenured Faculty } & 42 & 1 & 2.38 & 20 & 47.62 & 13 & 30.95 & 7 & 16.67 & 1 & 2.38 \\ & 33 & 0 & 0 & 8 & 24.24 & 14 & 42.42 & 8 & 24.24 & 3 & 9.09\end{array}$

$\begin{array}{llllllllllll}\text { Non-tenured Faculty } & 33 & 0 & 0 & 8 & 24.24 & 14 & 42.42 & 8 & 24.24 & 3 & 9.09\end{array}$

SI 22 Choosing president

Tenured Faculty

Non-tenured Faculty

$\begin{array}{lllllllllll}43 & 6 & 13.95 & 26 & 60.47 & 2 & 4.65 & 2 & 4.65 & 7 & 16.28\end{array}$

$\begin{array}{lllllllllll}33 & 0 & 0 & 5 & 15.15 & 5 & 15.15 & 4 & 12.12 & 19 & 57.58\end{array}$

SI 23 Faculty hiring, promo, \& tenure

Tenured Faculty

Non-tenured Faculty

$\begin{array}{ccccccccccl}43 & 13 & 30.23 & 28 & 65.12 & 2 & 4.65 & 0 & 0 & 0 & 0 \\ 32 & 2 & 6.25 & 18 & 56.25 & 3 & 9.38 & 3 & 9.38 & 6 & 18.75\end{array}$

Structural arrangements. Five survey items addressed structural arrangements (\#24, \#25, \#26, \#27, and \#28) and are reflected in Table 11.

As noted on item \#24, both tenured and non-tenured faculty were somewhat divided on their level of agreement with the statement that "structure and processes that allow for faculty collaboration are clearly defined in governance documents." Over 50\% (51.16\%) of tenured faculty strongly agreed or agreed, while $37.21 \%$ disagreed or strongly disagreed. Less than $50 \%$ $(45.45 \%)$ of non-tenured faculty agreed or strongly agreed, while almost $40 \%$ disagreed or strongly disagreed with the statement.

In response to the statement in item \#25 that "collaborative structures and processes are functioning in an effective manner," less than half of both tenured and non-tenured faculty agreed, with disagreement by $37.21 \%$ of tenured faculty and $24.24 \%$ of non-tenured faculty.

In response to the negatively worded statement in item \#26, "Our institution does not have a faculty senate or other institution-wide governance body that meets on a regular basis," a majority of both tenured (64.29\%) and non-tenured (59.38\%) faculty indicated they disagreed or strongly disagreed. 
As noted on item \#27, almost three-quarters of the tenured faculty $(74.36 \%)$ indicated they agreed or strongly agreed with the statement that "faculty members determine how their own representatives are selected to the senate/faculty governing body." Similarly, a majority of non-tenured faculty $(60.60 \%)$ agreed or strongly agreed. However, slightly more than $15 \%$ of non-tenured faculty indicated "I don't know," compared to $5.13 \%$ of the tenured faculty.

A majority of tenured (69.77\%) and non-tenured (62.50\%) faculty indicated they agreed or strongly agreed with the statement in item \#28 that faculty representation on joint committees appropriately reflects their stake in the issue being addressed.

Table 11

Faculty Perceptions

Item Governance Standard

Levels of Agreement

\begin{tabular}{|c|c|c|c|c|c|}
\hline \multirow{3}{*}{$n$} & Strongly & & & Strongly & I don't \\
\hline & Agree & Agree & Disagree & Disagree & Know \\
\hline & $\%$ & $\%$ & $\%$ & $\%$ & $\%$ \\
\hline
\end{tabular}

Structural Arrangements

SI 24 Governance documents define structure

Tenured Faculty

Non-tenured Faculty

\section{3}

33

SI 25 Structure and processes effective

Tenured Faculty

Non-tenured Faculty

$\begin{array}{lll}43 & 2 & 4.65\end{array}$

$\begin{array}{lll}33 & 2 & 6.06\end{array}$

18

12

41.86

36.36

39.53

36.36

$34.88 \quad 1$

30.30

$2.33 \quad 5$

$9.09 \quad 5$

11.63

15.15

SI 26 No faculty senate or similar

Tenured Faculty

Non-tenured Faculty

$\begin{array}{ccccccccccc}42 & 4 & 9.52 & 9 & 21.43 & 11 & 26.19 & 16 & 38.10 & 2 & 4.76 \\ 32 & 5 & 15.63 & 7 & 21.88 & 12 & 37.50 & 7 & 21.88 & 1 & 3.13\end{array}$

SI 27 Faculty determines representation

Tenured Faculty

Non-tenured Faculty $\begin{array}{llllll}39 & 13 & 33.33 & 16 & 41.03\end{array}$

$\begin{array}{llllll}33 & 5 & 15.15 & 15 & 45.45\end{array}$ $\begin{array}{llll}16 & 37.21 & 0\end{array}$

$\begin{array}{lll}8 & 24.24 & 4\end{array}$

$$
0
$$

$\begin{array}{ll}7 & 16.28\end{array}$

$\begin{array}{ll}7 & 21.21\end{array}$

SI 28 Faculty representation appropriate

Tenured Faculty

Non-tenured Faculty
43

$\begin{array}{lll}5 & 11.63 & 25\end{array}$

$\begin{array}{llll}32 & 2 & 6.25 & 18\end{array}$
$58.14 \quad 5$

56.25

$\begin{array}{rrrr}5.13 & 6 & 15.38 & 2 \\ 12.12 & 4 & 12.12 & 5\end{array}$


Research Question \#2. What are administrators' perceptions of the climate for shared governance?

There were a total of 89 administrator respondents in this study. This included cabinetlevel administrators (37) and other lower-level administrators who do not serve on cabinet (52).

Institutional climate. Survey items \#4, \#5, and \#11 addressed the matter of institutional climate, as reflected in Table 12.

As reflected on item \#4, a majority of cabinet-level administrators (97.29\%), as well as other administrators (86.79\%), agreed or strongly agreed that there was a culture of collegiality and respect on their campuses.

Well over three-quarters of cabinet-level administrators $(91.89 \%)$ and three-quarters of administrators (75.47\%) agreed or strongly agreed with the statement in item \#5 that "campus negotiations are carried out in good faith and an atmosphere trust."

In response to the statement in item \#11 that "the board supports the faculty's traditional role in shared governance," close to $100 \%$ of cabinet-level administrators $(97.30 \%)$ agreed or strongly agreed that the board supports the faculty's traditional role in shared governance, while close to $20 \%$ of the non-cabinet level administrators $(18.87 \%)$ indicated "I don't know." Table 12

Administrator Perceptions

Item Governance Standard

Levels of Agreement

\begin{tabular}{|c|c|c|c|c|c|}
\hline \multirow{3}{*}{$n$} & Strongly & & & Strongly & I don't \\
\hline & Agree & Agree & Disagree & Disagree & Know \\
\hline & $\%$ & $\%$ & $n \quad \%$ & $n \quad \%$ & $\%$ \\
\hline
\end{tabular}

Institutional Climate

SI 4 Culture of Collegiality and respect

Cabinet - level administrator

$\begin{array}{llll}37 & 12 & 32.43 & 24\end{array}$

64.86

2.70

0

$\begin{array}{lll}0 & 0 & 0\end{array}$



Administrator
$\begin{array}{lll}53 & 9 & 16.98\end{array}$
37
69.81

5
9.43
$1.89 \quad 1$

SI 5 Negotiations in good faith \& trust

Cabinet - level administrator

$\begin{array}{llll}37 & 9 & 24.32 & 25\end{array}$

67.57

$\begin{array}{llll}53 & 4 & 7.55 & 36\end{array}$

67.92

$\begin{array}{ccccc}5.41 & 0 & 0 & 1 & 2.70 \\ 13.21 & 4 & 7.55 & 2 & 3.77\end{array}$

SI 11 Board supports faculty's role Cabinet - level administrator Administrator

$\begin{array}{cccc}37 & 6 & 16.22 & 30 \\ 53 & 5 & 9.43 & 33\end{array}$

81.08

$\begin{array}{lllllll}62.26 & 5 & 9.43 & 0 & 0 & 10 & 18.87\end{array}$

Institutional communication. Survey items \#6 and \#7 addressed this standard and are shown on Table 13.

As reflected on item \#6, almost $95 \%$ of the cabinet-level administrators $(94.59 \%)$

indicated they agreed or strongly agreed that there was a process for consultation with faculty. Almost three-quarters of other administrators (73.58\%) also agreed or strongly agreed. A number of these administrators (16.98\%) also indicated "I don't know."

In response to the statement in item \#7 that "the faculty as a whole has timely access to information necessary to give input into governance processes," $83.78 \%$ of the cabinet-level administrators agreed or strongly agreed, while $66.04 \%$ of other administrators agreed or strongly agreed. Almost 19\% of the latter group also indicated "I don't know."

Table 13

Administrator Perceptions

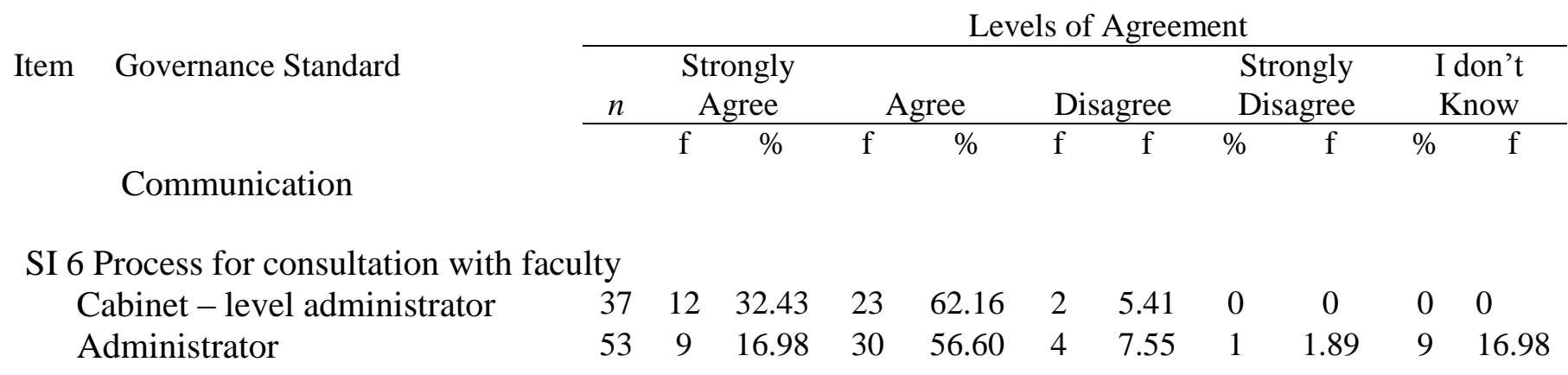


SI 7 Faculty has access to information

Cabinet - level administrator

$\begin{array}{llll}37 & 8 & 21.62 & 23\end{array}$

62.16

$\begin{array}{llll}53 & 9 & 16.98 & 26\end{array}$

49.06

$8.11 \quad 0$

$\begin{array}{ll}0 & 3\end{array}$

8.11

Administrator

40

The board's role. There were three survey items on the role of the board in shared governance, \#8, \#9, and \#10, as shown on Table 14.

As indicated on item \#8, a majority (89.18\%) of cabinet-level administrators agreed or strongly agreed that the board had appropriate individual qualifications with regard to education and experience. Other administrators (62.26\%) indicated they agreed or strongly agreed, while $20.75 \%$ disagreed or strongly disagreed, and $16.98 \%$ indicated “I don't know."

As reflected on item \#9, just over $86 \%$ of both cabinet-level administrators and other administrators agreed or strongly agreed that board members were not involved in daily operations.

As indicated on item \#10, cabinet-level administrators indicated they disagreed or strongly disagreed $(35.13 \%)$ that the board was informed on governance issues. Almost $22 \%$ indicated they did not know. Over $50 \%$ of the lower-level administrators indicated they did not know whether the board was informed on these matters.

Table 14

Administrator Perceptions

Item Governance Standard

Board's Role

\begin{tabular}{|c|c|c|c|c|c|}
\hline \multicolumn{6}{|c|}{ Levels of Agreement } \\
\hline$n$ & $\begin{array}{c}\text { Strongly } \\
\text { Agree }\end{array}$ & Agree & Disagree & $\begin{array}{l}\text { Strongly } \\
\text { Disagree }\end{array}$ & $\begin{array}{l}\text { I don't } \\
\text { Know }\end{array}$ \\
\hline & $\mathrm{n} \quad \%$ & $\mathrm{n} \quad \%$ & $\mathrm{n} \quad \%$ & $\mathrm{n} \quad \%$ & n $\quad \%$ \\
\hline
\end{tabular}

SI 8 Has appropriate qualifications Cabinet - level administrator Administrator

$\begin{array}{ccccccccccc}37 & 9 & 24.32 & 24 & 64.86 & 3 & 8.11 & 0 & 0 & 1 & 2.70 \\ 53 & 8 & 15.09 & 25 & 47.17 & 9 & 16.98 & 2 & 3.77 & 9 & 16.98\end{array}$


SI 9 Not involved in daily operations

Cabinet - level administrator

Administrator

$\begin{array}{llll}37 & 17 & 45.95 & 15\end{array}$

$\begin{array}{llll}53 & 15 & 28.30 & 31\end{array}$

40.54

5

13.5

0

$\begin{array}{lll}0 & 0 & 0\end{array}$

SI 10 Informed on governance issues

Cabinet - level administrator

Administrator

$\begin{array}{ccccccccccc}37 & 2 & 5.41 & 14 & 37.84 & 12 & 32.43 & 1 & 2.70 & 8 & 21.62 \\ 53 & 3 & 5.66 & 5 & 9.43 & 11 & 20.75 & 5 & 9.43 & 29 & 54.72\end{array}$

The president's role. Survey Items \#12, \#13, \#14, and \#15 addressed the role of the president, with responses as shown in Table 15.

As reflected on item \#12, a majority of both cabinet-level administrators (97.29\%) and lower-level administrators $(88.68 \%)$ agreed or strongly agreed that the president had appropriate credentials.

As indicated on item \#13, a majority of cabinet-level administrators (91.89\%) agreed or strongly agreed that the president rarely overturned faculty decisions, and $71.69 \%$ of other administrators agreed or strongly agreed, while $18.87 \%$ indicated "I don't know."

While $86.48 \%$ of cabinet-level administrators agreed or strongly agreed with the statement in item \#14 that the president sought faculty input on matters in which they have appropriate interest but not primary responsibility, $24.53 \%$ of other administrators disagreed, and $13.21 \%$ indicated "I don't know."

As indicated on item \#15, more than three-quarters of the cabinet-level administrators agreed or strongly agreed that the president effectively advocated shared governance to the board, while $38.46 \%$ of the other administrators indicated "I don't know."

Table 15

Administrator Perceptions

Levels of Agreement 
Item Governance Standard

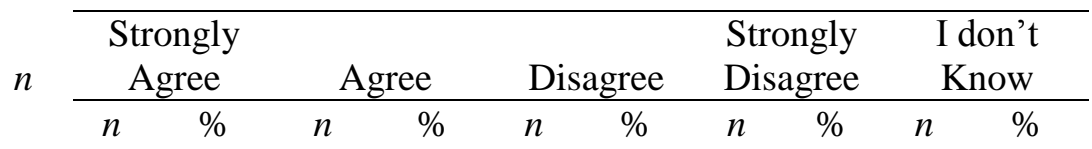

President's role

SI 12 Has appropriate credentials

$\begin{array}{lrrrrrrrrrrr}\text { Cabinet - level administrator } & 37 & 24 & 64.86 & 12 & 32.43 & 1 & 2.70 & 0 & 0 & 0 & 0\end{array}$

Administrator

$\begin{array}{lllllllllll}53 & 24 & 45.28 & 23 & 43.40 & 3 & 5.66 & 1 & 1.89 & 2 & 3.77\end{array}$

SI 13 Rarely overturns faculty decisions

$\begin{array}{llllllllllll}\text { Cabinet - level administrator } & 37 & 15 & 40.54 & 19 & 51.35 & 0 & 0 & 0 & 0 & 3 & 8.11\end{array}$

$\begin{array}{llllllllllll}\text { Administrator } & 53 & 11 & 20.75 & 27 & 50.94 & 5 & 9.43 & 0 & 0 & 10 & 18.87\end{array}$

SI 14 Seeks faculty input

$\begin{array}{llllllllllll}\text { Cabinet - level administrator } & 37 & 8 & 21.62 & 24 & 64.86 & 2 & 5.41 & 1 & 2.70 & 2 & 5.41\end{array}$

Administrator

$\begin{array}{lllllllllll}53 & 7 & 13.21 & 21 & 39.62 & 13 & 24.5 & 5 & 9.43 & 7 & 13.21\end{array}$

SI 15 Advocates shared governance

$\begin{array}{llllllllllll}\text { Cabinet-level administrator } & 37 & 11 & 29.73 & 18 & 48.65 & 5 & 13.5 & 0 & 0 & 3 & 8.11\end{array}$

$\begin{array}{llllllllllll}\text { Administrator } & 52 & 5 & 9.62 & 20 & 38.46 & 4 & 7.69 & 3 & 5.77 & 20 & 38.46\end{array}$

The faculty's role. Survey items \#16, \#17, \#18, and \#29 addressed the faculty's role in governance and are reflected in Table 16.

As reflected on item \#16, over $90 \%$ of the cabinet-level administrators agreed or strongly agreed that the faculty has autonomy in matters that are their primary responsibility, such as curriculum, tenure, and promotion. More than three-quarters of the other administrators agreed or strongly agreed.

As noted on item \#17, while three-quarters of the cabinet-level administrators indicated they agreed or strongly agreed that faculty exercised its capacity for both adverse and positive decisions in faculty personnel matters, $21.62 \%$ disagreed, and $24.53 \%$ of other administrators indicated "I don't know."

As reflected on item \#18, cabinet-level administrators (27.03\%) disagreed or strongly disagreed with the statement that "resources support faculty expertise in shared governance," 
while slightly more than $45 \%$ of other administrators disagreed or strongly disagreed, and

$20.75 \%$ of this group indicated "I don't know."

As noted on item \#29, cabinet-level administrators (59.46\%) agreed or strongly agreed that faculty members have input on academic administrative candidates. Other administrators (42.31\%) agreed or strongly agreed, while $40.38 \%$ disagreed or strongly disagreed, and $17.31 \%$ indicated "I don't know."

Table 16

Administrator Perceptions

\begin{tabular}{|c|c|c|c|c|c|c|c|c|c|c|c|c|}
\hline \multirow{4}{*}{ Item } & \multirow{4}{*}{$\begin{array}{l}\text { Governance Standard } \\
\text { Faculty's Role }\end{array}$} & \multicolumn{11}{|c|}{ Levels of Agreement } \\
\hline & & \multirow{2}{*}{\multicolumn{3}{|c|}{$\begin{array}{c}\text { Strongly } \\
\text { Agree }\end{array}$}} & \multirow{2}{*}{\multicolumn{2}{|c|}{ Agree }} & \multirow{2}{*}{\multicolumn{2}{|c|}{ Disagree }} & \multirow{2}{*}{\multicolumn{2}{|c|}{$\begin{array}{l}\text { Strongly } \\
\text { Disagree }\end{array}$}} & \multirow{2}{*}{\multicolumn{2}{|c|}{$\begin{array}{l}\text { I don't } \\
\text { Know }\end{array}$}} \\
\hline & & & & & & & & & & & & \\
\hline & & & $n$ & $\%$ & $n$ & $\%$ & $n$ & $\%$ & $n$ & $\%$ & $n$ & $\%$ \\
\hline \multicolumn{13}{|c|}{ SI 16 Has autonomy } \\
\hline & Cabinet - level administrator & 37 & 13 & 35.14 & 21 & 56.76 & 1 & 2.70 & 0 & 0 & 2 & 5.41 \\
\hline & Administrator & 53 & 11 & 20.75 & 31 & 58.49 & 6 & 11.32 & 0 & 0 & 5 & 9.43 \\
\hline \multicolumn{13}{|c|}{ SI 17 Exercises capacity for decisions } \\
\hline & Cabinet - level administrator & 37 & 5 & 13.51 & 23 & 62.16 & 8 & 21.62 & 0 & 0 & 1 & 2.70 \\
\hline & Administrator & 53 & 4 & 7.55 & 28 & 52.83 & 7 & 13.21 & 1 & 1.89 & 13 & 24.53 \\
\hline \multicolumn{13}{|c|}{ SI 18 Resources support expertise } \\
\hline & Cabinet - level administrator & 37 & 2 & 5.41 & 23 & 62.16 & 10 & 27.03 & 0 & 0 & 2 & 5.41 \\
\hline & Administrator & 53 & 1 & 1.89 & 17 & 32.08 & 18 & 33.96 & 6 & 11.32 & 11 & 20.75 \\
\hline \multicolumn{13}{|c|}{ SI 29 Input on academic candidates } \\
\hline & Cabinet - level administrator & 37 & 6 & 16.22 & 16 & 43.24 & 7 & 18.92 & 1 & 2.70 & 7 & 18.92 \\
\hline & Administrator & 53 & 5 & 9.62 & 17 & 32.69 & 17 & 32.69 & 4 & 7.69 & 9 & 17.31 \\
\hline
\end{tabular}

Joint decision making. Survey items \#19, \#20, \#21, \#22, and \#23 addressed this standard and are reflected on Table 17.

As indicated on item \#19, more than three-quarters of the cabinet-level administrators agreed or strongly agreed that there was joint decision making relative to long-range planning, while $27.45 \%$ of other administrators disagreed. 
In response to the statement in item \#20 that "there is joint responsibility for decision making regarding existing or prospective physical resources," slightly more than three-quarters of the cabinet-level administrators agreed or strongly agreed. However, $21.62 \%$ disagreed with the statement, as did $42.31 \%$ of the other administrators.

As reflected on item \#21, a majority $(81.08 \%)$ of cabinet-level administrators agreed or strongly agreed that there was joint decision making relative to the institutional budget, but more than half of other administrators disagreed or strongly disagreed.

Slightly more than $67 \%$ of cabinet-level administrators agreed or strongly agreed with the statement in item \#22 that there was joint responsibility in choosing a new president. Almost $31 \%$ of other administrators disagreed or strongly disagreed. More than $20 \%$ of both groups of administrators indicated "I don't know."

As reflected on item \#23, a majority of cabinet-level administrators and other administrators agreed or strongly agreed that there was joint decision making relative to faculty selection, promotion, and tenure. Both groups indicated "I don't know," with rates of $16.22 \%$ and $20.75 \%$ respectively.

Table 17

Administrator Perceptions

Item Governance Standard

Levels of Agreement

\begin{tabular}{|c|c|c|c|c|c|}
\hline$n$ & $\begin{array}{c}\text { Strongly } \\
\text { Agree }\end{array}$ & Agree & Disagree & $\begin{array}{l}\text { Strongly } \\
\text { Disagree }\end{array}$ & $\begin{array}{l}\text { I don't } \\
\text { Know }\end{array}$ \\
\hline & $n \quad \%$ & $n \quad \%$ & $n \quad \%$ & n $\%$ & $\%$ \\
\hline
\end{tabular}


Joint decision making

SI 19 Long range planning

Cabinet - level administrator

Administrator

$\begin{array}{llll}37 & 7 & 18.92 & 24\end{array}$

$\begin{array}{llll}51 & 4 & 7.84 & 29\end{array}$

64.86

$\begin{array}{lllllll}56.86 & 14 & 27.45 & 2 & 3.92 & 2 & 3.92\end{array}$

SI 20 Physical resources

Cabinet - level administrator

$\begin{array}{llll}37 & 3 & 8.11 & 25\end{array}$

$\begin{array}{llll}67.57 & 8 & 21.62 & 0\end{array}$

$\begin{array}{ll}1 & 2.70\end{array}$

Administrator

$\begin{array}{lll}52 & 2 & 3.82\end{array}$

SI 21 Institutional budgeting

Cabinet - level administrator

Administrator

$\begin{array}{llll}37 & 5 & 16.22 & 24\end{array}$

$\begin{array}{lll}52 & 2 & 3.85\end{array}$

17

32.69

22

42.31

$\begin{array}{lll}9.62 & 6 & 11.54\end{array}$

SI 22 Choosing president

Cabinet - level administrator

$\begin{array}{ccccccccccc}37 & 6 & 16.22 & 19 & 51.22 & 2 & 5.41 & 2 & 5.41 & 8 & 21.62 \\ 52 & 4 & 7.69 & 18 & 34.62 & 14 & 26.92 & 2 & 3.85 & 14 & 26.92\end{array}$

Administrator

24

$\begin{array}{llll}64.86 & 5 & 13.51 & 1\end{array}$

$\begin{array}{lll}2.70 & 1 & 2.70\end{array}$

$\begin{array}{lllllll}36.54 & 23 & 44.23 & 5 & 9.62 & 3 & 5.77\end{array}$

SI 23 Faculty hiring, promo, \& tenure

Cabinet - level administrator

$\begin{array}{llll}37 & 6 & 16.22 & 21\end{array}$

$\begin{array}{llll}53 & 9 & 16.98 & 28\end{array}$

56.76

5.41

$\begin{array}{ll}6 & 16.22\end{array}$

Administrator

53

.

Structural arrangements. A total of five survey items (\#24, \#25, \#26, \#27, and \#28)

addressed structural arrangements for governance, as shown in Table 18.

In response to the statement in item \#24 that governance documents define the process for faculty collaboration, both cabinet-level administrators (27.03\%) and other administrators (28.30\%) indicated "I don’t know" at similar rates.

As reflected on item $\# 25$, while $80.55 \%$ of cabinet-level administrators agreed or strongly agreed that the governance process was effective, almost $20 \%$ of other administrators disagreed, and 25\% indicated "I don't know."

In response to the negatively worded statement that "there is no faculty senate or similar in place," almost $90 \%$ of cabinet-level administrators disagreed or strongly disagreed, while almost $70 \%$ of other administrators disagreed or strongly disagreed.

Over $80 \%$ of cabinet-level administrators agreed or strongly agreed that faculty members determine how their representatives are selected to the faculty governing body. Almost $70 \%$ of 
other administrators agreed or strongly agreed, and $17.31 \%$ of this group indicated "I don't know."

The final survey item (\#28) in this section on structural arrangements states that faculty representation on joint committees appropriately reflects their stake in the issue being addressed. Well over three-quarters of the cabinet-level administrators agreed or strongly agreed. Other administrators (69.81\%) agreed or strongly agreed, while $16.98 \%$ indicated "I don't know."

Table 18

Administrator Perceptions

Item Standard

Levels of Agreement

\begin{tabular}{|c|c|c|c|c|c|}
\hline $\mathrm{n}$ & $\begin{array}{c}\text { Strongly } \\
\text { Agree }\end{array}$ & Agree & Disagree & $\begin{array}{l}\text { Strongly } \\
\text { Disagree }\end{array}$ & $\begin{array}{l}\text { I don't } \\
\text { Know }\end{array}$ \\
\hline & $n \quad \%$ & $n \quad \%$ & $n \%$ & $n \quad \%$ & $n \quad \%$ \\
\hline
\end{tabular}

Structural arrangements 
SI 24 Governance documents define structure

Cabinet - level administrator $\quad 37 \quad 3$

Administrator

53

SI 25 Structure and processes are effective

Cabinet - level administrator 36

Administrator

$\begin{array}{ll}36 & 3 \\ 52 & 3\end{array}$

$8.11 \quad 19$

51.35

$\begin{array}{llll}1.35 & 5 & 13.51 & 0\end{array}$

$\begin{array}{cc}10 & 27.03\end{array}$

$7.55 \quad 22$

41.51

$\begin{array}{lll}10 & 18.87 & 2\end{array}$

3.77

$15 \quad 28.30$

SI 26 No faculty senate or similar

Cabinet - level administrator

$\begin{array}{ccccccccccc}37 & 1 & 2.70 & 3 & 8.11 & 16 & 43.24 & 17 & 45.95 & 0 & \\ 53 & 4 & 7.55 & 9 & 16.98 & 22 & 41.51 & 15 & 28.30 & 3 & 5.66\end{array}$

SI 27 Faculty determines

Cabinet - level administrator

$\begin{array}{llll}37 & 12 & 32.43 & 18\end{array}$

$72.22 \quad 2$

$5.56 \quad 0$

$5 \quad 13.89$

Administrator

$\begin{array}{llll}52 & 11 & 21.15 & 25\end{array}$

48.65

$2 \quad 5.41 \quad 1$

$2.70 \quad 4$

10.81

SI 28 Faculty representation

Cabinet - level administrator

$\begin{array}{llll}37 & 4 & 10.81 & 29\end{array}$

48.08

$\begin{array}{lll}6 & 11.54 & 1\end{array}$

1.92

$9 \quad 17.31$

Administrator

$\begin{array}{llll}53 & 5 & 9.43 & 32\end{array}$

78.38

60.38

2.70

5.4

3.77

2.70

16.98

Research Question \#3. What are staff members' perceptions of the climate for shared governance? There were a total of 27 staff respondents in this study.

Institutional climate. Survey items \#4, \#5, and \#11 focused on institutional climate, as noted in Table 19.

As reflected on item \#4, almost $90 \%$ of staff members agreed or strongly agreed that there was a culture of collegiality and respect on their campuses.

However, as indicated on item \#5, over $25 \%$ disagreed with the statement that “negotiations among campus constituents are open and carried out in good faith and an atmosphere of trust."

As shown on item \#11, nearly $60 \%$ of staff members indicated they agreed that the board supported the faculty's traditional role in governance, while close to $40 \%$ indicated "I don't know."

Table 19

\section{Staff Perceptions}


Levels of Agreement

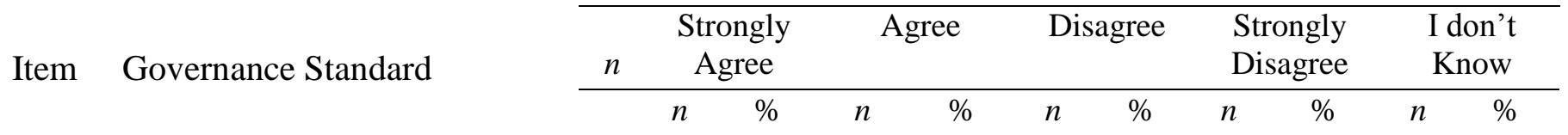

Institutional Climate

SI 4 Culture of collegiality and respect

Staff members 27

SI 5 Negotiations in good faith and trust

Staff members

SI 11 Board supports faculty's role

Staff member

$\begin{array}{rrrrrrrrrrr}27 & 3 & 11.11 & 16 & 59.26 & 7 & 25.93 & 0 & 0 & 1 & 3.70 \\ 27 & 0 & 0 & 16 & 59.26 & 1 & 3.70 & 0 & 0 & 10 & 37.04\end{array}$

Institutional communication. As shown on Table 20, two items addressed institutional communication.

As indicated by item \#6, 55\% of the staff members agreed or strongly agreed that there was a process for consultation with faculty, while 33.33\% indicated "I don't know."

Staff members (48.15\%) were more likely to choose "I don't know" (48.15\%) in response to the statement in item \#7 that "the faculty as a whole has timely access to information necessary for faculty members to give input into governance processes."

Table 20

Staff Perceptions

Item Governance Standard

Levels of Agreement

\begin{tabular}{ccccccc}
\hline & $\begin{array}{c}\text { Strongly } \\
n\end{array}$ & & & Strongly & I don't \\
Agree & Agree & Disagree & \multicolumn{2}{c}{$\begin{array}{c}\text { Disagree } \\
\text { Know }\end{array}$} \\
\hline
\end{tabular}

Institutional Communication 
SI 6 Process for consultation with faculty

Staff members 27

SI 7 Faculty has access to information

Staff members

$\begin{array}{llll}27 & 2 & 7.41 & 11\end{array}$

44.44

3

11.11

0

$\begin{array}{ll}0 & 9\end{array}$

33.33

Staff members

40.74

3.70

$0 \quad 0$

$13 \quad 48.15$

The board's role. Survey items \#8, \#9, and \#10, as shown on Table 21, addressed the role of the board in governance.

As reflected on item \#8, a majority of staff members $(70.37 \%)$ indicated they agreed or strongly agreed that board members had appropriate qualifications, while $22.22 \%$ indicated "I don't know."

As indicated on item $\# 9$, while $66.66 \%$ agreed or strongly agreed that the board was not involved in daily operations, almost $15 \%$ disagreed, and $18.52 \%$ indicated "I don't know."

A majority (74.07\%) chose "I don't know" in response to the statement in item \#10 that the board was informed on governance issues.

Table 21

Staff Perceptions

Item Governance Standard

Board's Role
Levels of Agreement

\begin{tabular}{cccccccc}
\hline & $\begin{array}{c}\text { Strongly } \\
n\end{array}$ & & & & \multicolumn{2}{c}{$\begin{array}{c}\text { Strongly } \\
\text { Agree }\end{array}$} & \multicolumn{2}{c}{ Agree } & Disagree & \multicolumn{2}{c}{$\begin{array}{c}\text { D don't } \\
\text { Disagree }\end{array}$} & \multicolumn{2}{c}{ Know } \\
\hline
\end{tabular}


SI 8 Has appropriate qualifications

Staff members

$\begin{array}{llllllllll}27 & 5 & 18.52 & 14 & 51.85 & 2 & 7.41 & 0 & 0 & 6\end{array}$

22.22

SI 9 Not involved in daily operations

Staff members

$\begin{array}{llll}27 & 1 & 3.70\end{array}$

17

62.96

$\begin{array}{lll}4 & 14.81 & 0\end{array}$

$0 \quad 5$

18.52

SI 10 Informed on governance issues

Staff members

$27 \quad 0 \quad 0 \quad 3$

11.113

$11.11 \quad 1$

3.70

$20 \quad 74.07$

The president's role. Four survey items, \#12, \#13, \#14, and \#15, addressed the role of the president in the governance process, as reflected in Table 22.

Well over three-quarters $(85.18 \%)$ of staff members agreed or strongly agreed with the statement in item \# 12 that "the president has appropriate credentials."

As indicated on item \#13, while over 50\% agreed or strongly agreed that the president rarely overturned faculty decisions, 37.04\% indicated "I don't know."

Almost $50 \%$ of the staff members responding indicated "I don't know" in response to the statement in item \#14 that "the president seeks faculty input on matters that are his or her primary responsibility (such as budgeting) in which the faculty has an appropriate interest but not primary responsibility." While almost $63 \%$ agreed or strongly agreed that the president effectively advocated shared governance to the governing board, nearly $30 \%$ indicated "I don't know."

Table 22

Staff Perceptions

Item Governance Standard

Levels of Agreement

\begin{tabular}{|c|c|c|c|c|c|}
\hline$n$ & $\begin{array}{l}\text { Strongly } \\
\text { Agree }\end{array}$ & Agree & Disagree & $\begin{array}{l}\text { Strongly } \\
\text { Disagree }\end{array}$ & $\begin{array}{l}\text { I don't } \\
\text { Know }\end{array}$ \\
\hline & $n \quad \%$ & $n \quad \%$ & $n \quad \%$ & $n \quad \%$ & $n \quad \%$ \\
\hline
\end{tabular}

President's Role 
SI 12 Has appropriate credentials

Staff members

$\begin{array}{llll}27 & 14 & 51.85 & 9\end{array}$

33.33

3

11.11

0

$0 \quad 1$

3.70

SI 13 Rarely overturns faculty decisions

Staff members

$\begin{array}{llll}27 & 4 & 14.81 & 11\end{array}$

40.74

2

7.41

0

0

$10 \quad 37.04$

SI 14 Seeks faculty input

Staff members

27

3.70

10

37.04

3

$11.11 \quad 0$

0

$13 \quad 48.15$

SI 15 Advocates shared governance

Staff members

$\begin{array}{llllllllll}27 & 3 & 11.11 & 14 & 51.85 & 2 & 7.41 & 0 & 0 & 8\end{array}$

29.63

The faculty's role. As reflected in Table 23, four survey items addressed the faculty's role, \#16, \#17, \#18, and \#29.

Over $50 \%$ of the staff members responding to item \# 16 indicated they agreed or strongly agreed that the faculty had autonomy with regard to its primary responsibility. However, almost $27 \%$ indicated "I don't know."

Forty-eight percent of staff members indicated they agreed with the statement in item \#17 that "the faculty appropriately exercises its capacity for both adverse and positive decisions in faculty personnel matters." However, 48\% indicated "I don't know."

As noted on item \#18, a majority of staff members (68\%) chose "I don't know" in response to the statement that "the faculty has an opportunity to meet and comment on 'shortlisted' academic administrative candidates before hiring decisions are made."

As reflected on item $\# 29,41.66 \%$ of staff members agreed or strongly agreed that faculty has input on academic administrative candidates, while 50\% indicated "I don't know." Table 23

Staff Perceptions

Item Governance Standard

Levels of Agreement

\begin{tabular}{cccccc}
\hline & Strongly & & & Strongly & I don't \\
$n$ & Agree & Agree & Disagree & Disagree & Know \\
\hline
\end{tabular}




\begin{tabular}{llllllllll}
\hline$n$ & $\%$ & $n$ & $\%$ & $n$ & $\%$ & $n$ & $\%$ & $n$ & $\%$
\end{tabular}

Faculty's Role

SI 16 Has Autonomy

$\begin{array}{llllllllllll}\text { Staff Members } & 26 & 2 & 7.69 & 12 & 46.15 & 5 & 19.23 & 0 & 0 & 7 & 26.92\end{array}$

SI 17 Exercises capacity for decisions
$\begin{aligned} & \text { Staff Members } \\ & 25\end{aligned}$

SI 18 Resources support faculty expertise

$\begin{array}{llllllllllll}\text { Staff Members } & 25 & 0 & 0 & 3 & 12.00 & 5 & 20.00 & 0 & 0 & 17 & 68.00\end{array}$

SI 29 Faculty has input on candidates

Staff Members

$\begin{array}{lllllllllll}24 & 2 & 8.33 & 8 & 33.33 & 1 & 4.17 & 1 & 4.17 & 12 & 50.00\end{array}$

Joint decision making. There are five survey items which addressed this standard of governance, \#19, \#20,\#21, \#22, and \#23, as reflected in Table 24.

As indicated on item \#19, a majority of staff members (76\%) agreed or strongly agreed that there was joint decision making in the area of long range planning.

On item \#20, 56\% agreed that there was joint decision making relative to existing or prospective physical resources, while $28 \%$ disagreed.

Slightly more than $30 \%$ of staff members disagreed with the statement in item \#21 that there was joint responsibility for decision making in institutional budgeting.

As indicated on item \#22, nearly $60 \%$ of staff respondents agreed or strongly agreed there was joint responsibility in decision making regarding a new president, while $20.83 \%$ indicated "I don't know."

On item \#23, over 50\% indicated "I don't know" relative to the joint responsibility for decision making in faculty selection, promotion, and tenure.

Table 24

Staff Perceptions

Item Governance Standard

Levels of Agreement

Strongly Strongly I don't


Joint Decision Making

\begin{tabular}{|c|c|c|c|c|c|}
\hline$n$ & Agree & Agree & Disagree & Disagree & Know \\
\hline & $\%$ & $\%$ & $n \quad \%$ & $n \quad \%$ & $n \quad \%$ \\
\hline
\end{tabular}

SI 19 Long-range planning

Staff members

$\begin{array}{lllllllllll}27 & 1 & 4.00 & 18 & 72.00 & 2 & 8.00 & 0 & 0 & 4 & 16.00\end{array}$

SI 20 Physical resources

Staff members

SI 21 Institutional budgeting

Staff members

$\begin{array}{lllllllllll}25 & 0 & 0 & 14 & 56.00 & 7 & 28.00 & 0 & 0 & 4 & 16.00\end{array}$

SI 22 Choosing president

Staff members
SI 23 Faculty hiring, promotion, \& tenure

$\begin{array}{llllllllll}23 & 1 & 4.35 & 10 & 43.48 & 7 & 30.43 & 0 & 0 & 5\end{array}$

521.74

Staff members

$24 \quad 3$

$12.50 \quad 1$

11

45.83

$4 \quad 16.67 \quad 1$

$4.17 \quad 5$

520.83

$\begin{array}{lllllllllll}24 & 1 & 4.17 & 9 & 37.50 & 1 & 4.17 & 0 & 0 & 13 & 54.17\end{array}$

Structural arrangements. As shown in Table 25, survey items \#24, \#25, \#26, \#27, and \#28 addressed this standard of governance.

As indicated on item \#24, a majority (66.67\%) of staff chose "I don't know" in response to the statement that "structure and processes that allow for faculty governance are clearly defined in governance documents."

As noted on item \#25, 50\% of staff members chose "I don't know" in response to the statement about whether governance processes are effective.

More than three quarters of the staff members indicated they disagreed or strongly disagreed with the statement in item \#26 that there was no faculty senate or similar organization in place.

For item \#27, while almost $45 \%$ indicated their agreement that faculty determines their representation on the faculty governing body, $45.83 \%$ indicated "I don't know."

As indicated by item \#28, over $60 \%$ of the staff members indicated they agreed or strongly agreed that faculty representation on joint committees was an appropriate reflection of their stake in the issue being addressed, while $30.43 \%$ indicated "I don't know." 
Table 25

Staff Perceptions

Item Governance Standard

Levels of Agreement

\begin{tabular}{|c|c|c|c|c|c|}
\hline & Strongly & & & Strongly & I don't \\
\hline$n$ & Agree & Agree & Disagree & Disagree & Know \\
\hline
\end{tabular}

Structural Arrangements

SI 24 Documents define structure

$\begin{array}{lllllllllllll}\text { Staff Members } & 24 & 0 & 0 & 8 & 33.33 & 0 & 0 & 0 & 0 & 16 & 66.67\end{array}$

SI 25 Structure and processes effective

$\begin{array}{llllllllllll}\text { Staff Members } & 24 & 0 & 0 & 9 & 37.50 & 3 & 12.50 & 0 & 0 & 12 & 50.00\end{array}$

SI 26 No faculty senate or similar

$\begin{array}{llllllllllll}\text { Staff Members } & 24 & 0 & 0 & 2 & 8.33 & 12 & 50.00 & 7 & 29.17 & 3 & 12.50\end{array}$

SI 27 Faculty determines representation

Staff Members 24

SI 28 Faculty representation appropriate

$\begin{array}{lllllllllllll}\text { Staff Members } & 23 & 1 & 4.35 & 13 & 56.52 & 2 & 8.70 & 0 & 0 & 7 & 30.43\end{array}$

Research Question \#4: What is the perceived climate for shared governance at ACA institutions? The following section is based on the statistical analysis of aggregated responses by tenured and non-tenured faculty, administrators and cabinet-level administrators, and staff at participating ACA schools, as reflected on the tables noted for each governance standard.

Institutional climate. There were three survey items on this standard, including \#4, \#5, and \#11, as reflected in Table 26.

Survey item \#4 stated "There is a culture of collegiality and respect on our campus." Close to $90 \%$ of survey respondents indicated they agreed or strongly agreed with the statement. However, slightly more than $10 \%$ disagreed or strongly disagreed.

Close to three-quarters of respondents indicated they agreed or strongly agreed with the statement in item \#5 that campus negotiations were "carried out in good faith and an atmosphere of trust." Close to one-quarter indicated they disagreed or strongly disagreed. 
As indicated on item \#11, a majority of respondents agreed or strongly agreed that the board supported the faculty's traditional role in governance, while over $20 \%$ indicated "I don't know."

Table 26

Perceived Climate at ACA Schools

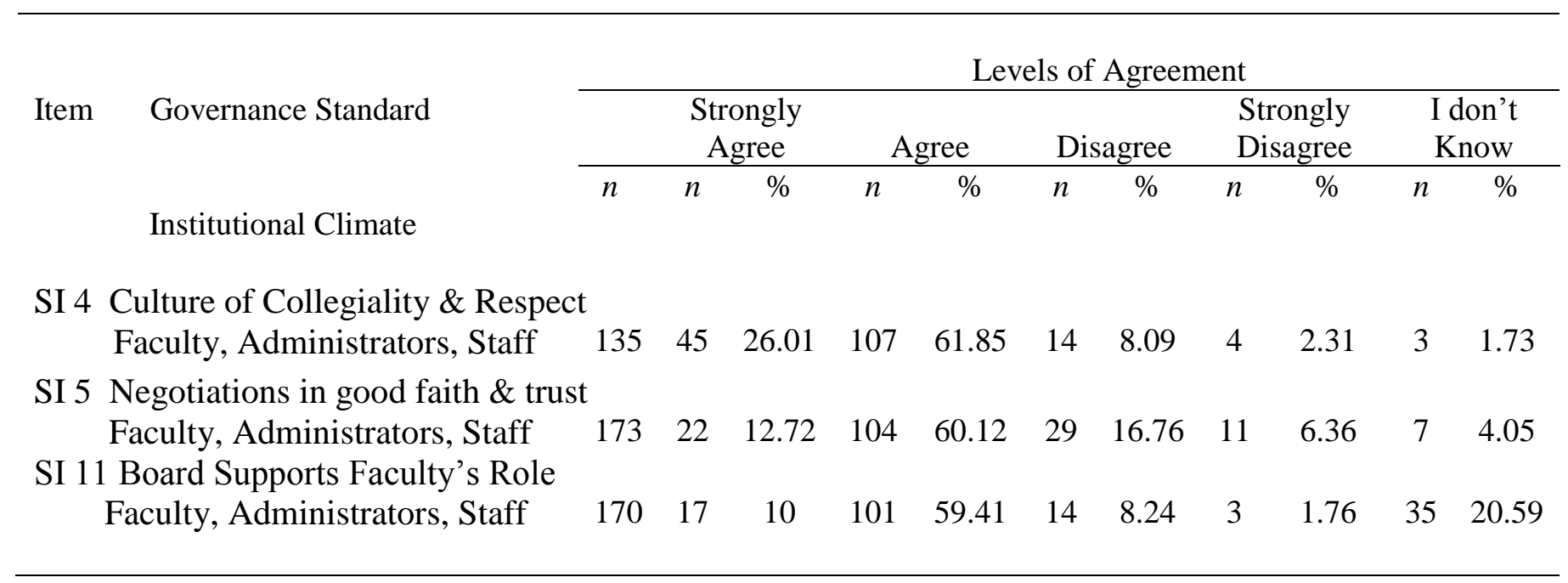

Institutional communication. Two survey items (\#6 and \#7) addressed institutional communication and are shown in Table 27.

As indicated on item \# 6, more than three-quarters of the respondents $(77.46 \%)$ indicated they agreed or strongly agreed that there was a process for consultation with faculty leadership. Close to $11 \%$ indicated "I don't know."

In response to the statement in item \# 7 that "the faculty as a whole has timely access to information necessary for faculty members to give input into governance processes," $59.53 \%$ indicated they agreed or strongly agreed, while almost $25 \%$ indicated they disagreed or strongly disagreed. More than 15\% indicated "I don't know."

Table 27

Perceived Climate at ACA Schools 
Item Governance Standard

Institutional communication

SI 6 Process for consultation Faculty, Administrators, Staff

SI 7 Whole faculty has information Faculty, Administrators, Staff

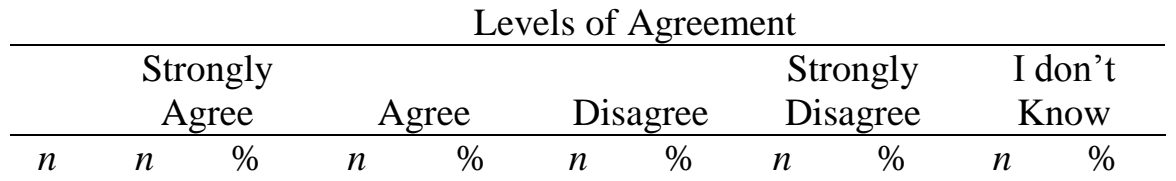

173

620.8

$98 \quad 56.56 \quad 16$

$9.25 \quad 4$

2.31

$19 \quad 10.98$

$\begin{array}{lllllllllll}173 & 24 & 13.87 & 79 & 45.66 & 33 & 19.08 & 10 & 5.78 & 27 & 15.61\end{array}$

The board's role. Three survey items (\#8, \#9, and \#10) as reflected on Table 28

addressed the role of the governing board.

As indicated on item \#8, while $62.65 \%$ of the respondents indicated they agreed or strongly agreed that board members had appropriate education and experience, $21.84 \%$ indicated "I don’t know."

Survey item \#9 was negatively worded: Board members are not involved in the day-today operations of the institution. More than three quarters of the respondents indicated they agreed or strongly agreed with the statement, while $13.79 \%$ indicated "I don't know."

In response to survey item \#10 stating that board members are informed on governance issues, close to $60 \%$ of the ACA respondents indicated "I don't know."

Table 28

Perceived Climate at ACA Schools

Item Governance Standard

Levels of Agreement

\begin{tabular}{|c|c|c|c|c|c|}
\hline$n$ & $\begin{array}{c}\text { Strongly } \\
\text { Agree }\end{array}$ & Agree & Disagree & $\begin{array}{l}\text { Strongly } \\
\text { Disagree }\end{array}$ & $\begin{array}{l}\text { I don't } \\
\text { Know }\end{array}$ \\
\hline & $n \quad \%$ & $n \quad \%$ & $n \quad \%$ & $n \quad \%$ & $\%$ \\
\hline
\end{tabular}




\section{Board's Role}

SI 8 Has appropriate qualifications Faculty, Administrators, Staff

$$
\begin{array}{llll}
174 & 27 & 16.51 & 82
\end{array}
$$

21

12.07

$\begin{array}{lll}6 & 3.45 & 38\end{array}$

SI 9 Not involved in daily operations Faculty, Administrators, Staff

$174 \quad 55$

SI10 Informed on governance

Faculty, Administrators, Staff

$\begin{array}{llll}173 & 5 & 2.89 & 28\end{array}$

16.18

$31 \quad 17.92 \quad 6$

3.47

$103 \quad 59.54$

The president's role. Four survey items (\#12, \#13, \#14, and \#15) addressed the role of the president in the governance process, and responses are shown on Table 29.

As indicated on item \#12, slightly more than $90 \%$ of respondents indicated they agreed or strongly agreed that the president had adequate academic and administrative credentials to serve as chief executive officer.

More than three-quarters of respondents indicated they agreed or strongly agreed with the statement in item \#13 that the president rarely overturned faculty decisions and recommendations in areas in which the faculty has primary responsibility. Almost 16\% indicated "I don't know." One comment noted that "[the use of] 'rarely' is tricky here. Because he has done this on a few occasions, there is a very low level of trust."

In response to the item \#14 statement, "The president seeks faculty input on matters that are his or her primary responsibility (such as budgeting) in which the faculty has an appropriate interest but not primary responsibility," $63.31 \%$ of respondents agreed or strongly agreed, while more than $20 \%$ disagreed or strongly disagreed, and almost $16 \%$ indicated "I don't know."

In response to item \#15, slightly more than $35 \%$ indicated "I don't know" relative to the statement that the president effectively advocates shared governance to the board.

Table 29 


\begin{tabular}{|c|c|c|c|c|c|c|c|c|c|c|c|c|}
\hline \multirow{4}{*}{ Item } & \multirow[b]{3}{*}{ Governance Standard } & \multicolumn{11}{|c|}{ Levels of Agreement } \\
\hline & & \multicolumn{3}{|c|}{$\begin{array}{c}\text { Strongly } \\
\text { Agree }\end{array}$} & \multicolumn{2}{|c|}{ Agree } & \multicolumn{2}{|c|}{ Disagree } & \multicolumn{2}{|c|}{$\begin{array}{l}\text { Strongly } \\
\text { Disagree }\end{array}$} & \multicolumn{2}{|c|}{$\begin{array}{l}\text { I don't } \\
\text { Know }\end{array}$} \\
\hline & & $n$ & $n$ & $\%$ & $n$ & $\%$ & $n$ & $\%$ & $n$ & $\%$ & $n$ & $\%$ \\
\hline & \multicolumn{12}{|l|}{ President's Role } \\
\hline \multicolumn{13}{|c|}{ SI 12 Has appropriate credentials } \\
\hline & Faculty, Administrators, Staff & 171 & 82 & 47.95 & 72 & 42.11 & 7 & 4.09 & 4 & 2.34 & 6 & 3.51 \\
\hline \multicolumn{13}{|c|}{ SI 13 Rarely overturns faculty } \\
\hline & Faculty, Administrators, Staff & 171 & 49 & 47.37 & 81 & 28.65 & 11 & 6.43 & 3 & 1.75 & 27 & 15.79 \\
\hline \multicolumn{13}{|c|}{ SI 14 Seeks faculty input } \\
\hline & Faculty, Administrators, Staff & 169 & 24 & 14.20 & 83 & 49.11 & 24 & 14.20 & 11 & 6.51 & 27 & 15.98 \\
\hline \multicolumn{13}{|c|}{ SI 15 Advocates shared governance } \\
\hline & Faculty, Administrators, Staff & 171 & 26 & 15.20 & 65 & 38.01 & 13 & 7.60 & 6 & 3.51 & 61 & 35.67 \\
\hline
\end{tabular}

The faculty's role. Four survey items (\#16, \#17, \#18, and \#29) as reflected on Table 30 addressed the role of faculty in the decision-making process at ACA schools.

On item \#16, a majority of faculty, administrators and staff (73.96\%) agreed or strongly agreed that the faculty is afforded an appropriate degree of autonomy with regard to its area of primary responsibility, while $16.57 \%$ disagreed or strongly disagreed. 
As indicated on item \#17, while $60.35 \%$ of respondents indicated they agreed or strongly agreed that faculty appropriately exercises its capacity for both adverse and positive decisions in faculty personnel matters, $19.53 \%$ disagreed or strongly disagreed, and $20.12 \%$ indicated "I don't know."

Responses were somewhat divided on the statement in item \#18 that "resources for faculty development, reward structures, and workloads supports the development of faculty expertise in shared governance." While $35.72 \%$ indicated they agreed or strongly agreed, $43.45 \%$ disagreed or strongly disagreed. More than 20\% indicated "I don't know."

For item \#29, while more respondents (47.59\%) agreed or strongly agreed than disagreed with the statement that the whole faculty has a chance to meet and comment on short-listed academic administrative candidates before hiring decisions are made, 33.13\% disagreed or strongly disagreed, and 19.28\% indicated "I don't know."

Table 30

Perceived Climate at ACA Schools

\begin{tabular}{|c|c|c|c|c|c|c|c|c|c|}
\hline \multirow[b]{3}{*}{ Item } & \multirow[b]{3}{*}{ Governance standards } & \multicolumn{8}{|c|}{ Levels of Agreement } \\
\hline & & & & & Agree & Disagree & $\begin{array}{l}\text { Strongly } \\
\text { Disagree }\end{array}$ & & \\
\hline & & $n$ & $n$ & $\%$ & $n \quad \%$ & $n \quad \%$ & $n \quad \%$ & $n$ & $\%$ \\
\hline
\end{tabular}

SI 16 Has autonomy 


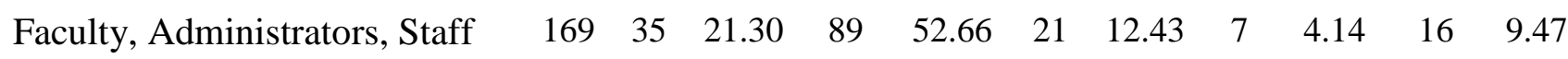

SI 17 Exercises capacity for decisions

Faculty, Administrators, Staff

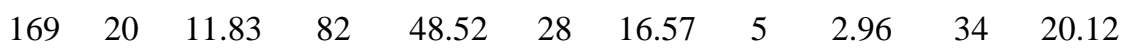

SI 18 Resources support faculty

Faculty, Administrators, Staff $\quad \begin{array}{lllllllllll}169 & 5 & 2.98 & 55 & 32.74 & 56 & 33.33 & 17 & 10.12 & 35 & 20.83\end{array}$

SI 29 Has input on candidates

$\begin{array}{llllllllllll}\text { Faculty, administrators, staff } & 166 & 17 & 10.24 & 62 & 37.35 & 39 & 23.49 & 16 & 9.64 & 32 & 19.28\end{array}$

Joint decision making. Five survey items addressed joint decision making (\#19, \#20, $\# 21$, \#22, and \#23), as reflected in Table 31.

As indicated on item \#19, while $66.47 \%$ of respondents indicated they agreed or strongly agreed that there was joint responsibility for long range planning, $26.94 \%$ indicated they disagreed or strongly disagreed.

While $46.95 \%$ of respondents agreed or strongly agreed with the statement in item \#20 that there is joint responsibility for decision making regarding existing or prospective resources, $43.30 \%$ indicated they disagreed or strongly disagreed.

In response to the item \#21 statement that "there is joint responsibility for decision making in institutional budgeting," responses were somewhat divided between disagreement (43.04\%) and agreement (49.09\%). Comments ranged from "There is a campus-wide budget committee," to "Very strongly disagree. Actually the faculty representative was recently told she 'didn't need to attend' the upcoming meeting where the budget was being discussed."

On item \#22, while $50 \%$ of the respondents agreed or strongly agreed there is joint responsibility for decision making in the selection of a new president, $31.33 \%$ indicated "I don't know." 
A majority of respondents $(69.70 \%)$ indicated they agreed or strongly agreed there was joint responsibility for decision making in faculty selection and promotion and the granting of tenure. However, 20\% indicated "I don’t know."

Table 31

Perceived Climate at ACA Schools

Item Governance Standard

\begin{tabular}{|c|c|c|c|c|}
\hline \multicolumn{5}{|c|}{ Levels of Agreement } \\
\hline $\begin{array}{c}\text { Strongly } \\
\text { Agree }\end{array}$ & Agree & Disagree & $\begin{array}{l}\text { Strongly } \\
\text { Disagree }\end{array}$ & $\begin{array}{l}\text { I don't } \\
\text { Know }\end{array}$ \\
\hline$n \quad \%$ & $n \quad \%$ & $n \quad \%$ & $n \quad \%$ & $n \quad \%$ \\
\hline
\end{tabular}

Joint Decision Making

SI 19 Long range planning

Faculty, Administrators, Staff $\quad \begin{array}{llllllllllll}167 & 19 & 11.38 & 92 & 55.09 & 31 & 18.56 & 14 & 8.38 & 11 & 6.59\end{array}$

SI 20 Physical resources

Faculty, Administrators, Staff $\quad \begin{array}{llllllllllll} & 167 & 6 & 3.66 & 71 & 43.29 & 56 & 34.15 & 15 & 9.15 & 16 & 9.76\end{array}$

SI 21 Institutional budgeting

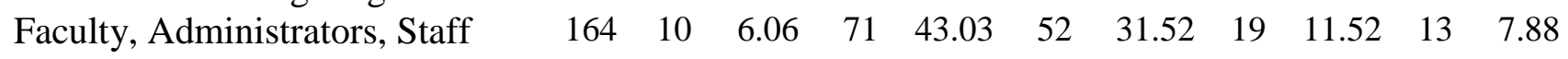

SI 22 Choosing president

Faculty, Administrators, Staff $\quad \begin{array}{llllllllllll}166 & 16 & 9.64 & 67 & 40.36 & 23 & 13.86 & 8 & 4.82 & 52 & 31.33\end{array}$

SI 23 Faculty hiring, promotion, and tenure

Faculty, Administrators, Staff $\quad \begin{array}{lllllllllll}166 & 24 & 14.55 & 91 & 55.15 & 10 & 6.06 & 7 & 4.24 & 33 & 20.0\end{array}$

Structural arrangements. Five survey items (\#24, \#25, \#26, \#27, and \#28) addressed structural arrangements at ACA schools, as reflected in Table 32.

In response to the statement in item \#24 that the structure and processes that allow for faculty collaboration are clearly defined in governance documents, $47.90 \%$ agreed or strongly agreed, while $27.54 \%$ indicated "I don't know." Close to $25 \%$ disagreed or strongly disagreed. 
On item \#25, while $50.91 \%$ of respondents agreed or strongly agreed that collaborative structures and processes are functioning in an effective manner, almost $25 \%$ disagreed or strongly disagreed, and $24.24 \%$ indicated "I don't know."

Survey item \#26 was a negatively worded statement: Our institution does not have a faculty senate or other institution-wide governance body that meets on a regular basis. Nearly three-quarters of the respondents disagreed or strongly disagreed.

On item \#27, while $66.05 \%$ of respondents indicated they agreed or strongly agreed that faculty members determine how their own representatives are selected to the senate/faculty governing body, $17.28 \%$ indicated "I don't know."

As indicated on item \#28, while a majority of respondents indicated they agreed or strongly agreed that faculty are appropriately represented on joint committees based on their stake in the issue being addressed, 16.97\% indicated "I don't know."

Table 32

Perceived Climate at ACA Schools

Item Governance standard

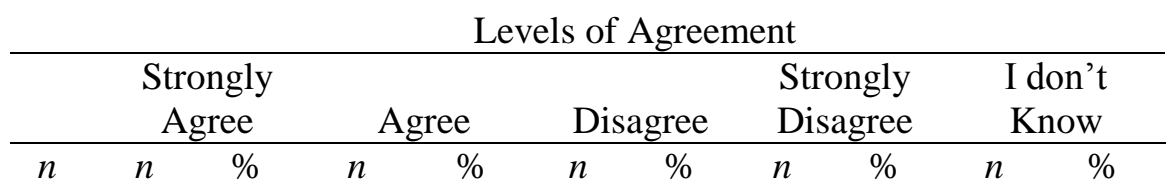


Structural Arrangements

SI 24 Documents define structure

Faculty, Administrators, Staff

$\begin{array}{lllllllllll}167 & 13 & 7.78 & 67 & 40.12 & 36 & 21.56 & 5 & 2.99 & 46 & 27.54\end{array}$

SI 25 Structure and collaborative processes effective

Faculty, Administrators, Staff $\quad \begin{array}{lllllllllll}165 & 7 & 4.24 & 77 & 46.67 & 36 & 21.82 & 5 & 3.03 & 40 & 24.24\end{array}$

SI 26 No faculty senate or similar

Faculty, Administrators, Staff $\quad \begin{array}{llllllllllll}165 & 11 & 6.67 & 26 & 15.67 & 65 & 39.39 & 54 & 32.73 & 9 & 5.45\end{array}$

SI 27 Faculty determines representation

$\begin{array}{llllllllllll}\text { Faculty, Administrators, Staff } & 162 & 33 & 20.37 & 74 & 45.68 & 16 & 9.88 & 11 & 6.79 & 28 & 17.28\end{array}$

SI 28 Faculty representation is appropriate

$\begin{array}{llllllllllll}\text { Faculty, Administrators, Staff } & 165 & 15 & 9.09 & 97 & 58.79 & 15 & 9.09 & 10 & 6.06 & 28 & 16.97\end{array}$

\section{Chapter Five: Summary, Conclusions, and Recommendations}

This chapter presents a summary of the study, conclusions from the research, and recommendations for practice and future research related to shared governance.

\section{Summary}


Shared governance has traditionally been a hallmark of the decision-making process in American higher education. This tradition rests on the assumption that faculty should hold a substantive role in decision making, along with governing boards and administration (CHEPA, 2003).

However, the rapidly changing higher education environment has fostered questions and controversy about the effectiveness of the shared governance model, which has been characterized by some as a hindrance to strategic thinking and nimble action (AFT, 2006; Bok, 2013). This is in spite of national studies which indicate that shared governance is considered valuable by institutions of higher education (AGB, 2009a; CHEPA, 2003).

Wellman (2006) characterizes the benefits of shared governance in this way: "Above all, shared governance is supposed to protect institutions from short-term political trends, ensure stability, and guard the institution from intellectual fads or inappropriate control of the institution by single-interest groups" (p. 53).

There have been numerous studies on shared governance throughout the years, including more recent national surveys and reports from the Association of Governing Boards of Colleges and Universities (AGB, 2009b; AGB, 2010; AGB, 2012). However, none has included research on the key standards outlined in AAUP documents since its seminal statement on shared governance in 1966. Given the historical importance of shared governance, the purpose of this study was to investigate how faculty, administrators, and staff perceived the climate for shared governance at 36 member institutions of the Appalachian College Association, based on standards for sound shared governance in higher education as outlined by the American Association of University Professors (AAUP). . 
Research was conducted by surveying campus constituents deemed knowledgeable about governance and decision-making processes by their presidents or vice presidents for academic affairs at their respective institutions of higher education. Because shared governance has traditionally characterized the decision making model at most small, independent institutions of higher education, the ACA, a consortium of such institutions, provided a convenient site for this research study.

Campus perceptions regarding the climate for governance, based on seven standards for shared governance as outlined by the AAUP, were collected via a link to a brief, anonymous online survey that was e-mailed to faculty, administrators, and staff at all participating ACA institutions. Their perceptions are reported in Chapter 4 through aggregate descriptive data from the survey results.

\section{Conclusions from the Research Questions}

Research Question \#1 conclusion. What are faculty members' perceptions of the climate for shared governance at their institutions?

The results of this study indicated that there were generally differences of perceptions between tenured and non-tenured faculty on a number of the seven standards relative to the climate for shared governance, with tenured faculty more often inclined to respond in agreement or strong agreement with the positively worded survey items. The following highlights comments from tenured and non-tenured faculty to provide further insight into their differing perceptions.

Regarding the institutional climate standard, non-tenured faculty members were less likely to agree that there was an atmosphere of negotiating in good faith and trust. One non- 
tenured faculty member noted, "Our administration dictates policy, often changing it on a whim, and faculty are not consulted. At best, we are asked to rubber stamp policy changes that have already been implemented." Another said, "The administration is dominating and suffocating in its duties. All decisions are made by the president of the college, therefore bypassing committees and faculty input."

Also, there were differing perceptions between both tenured and non-tenured faculty about whether structure and processes that allow for faculty collaboration are clearly defined in the governance documents, and whether the institution has a faculty senate or other governance body that meets regularly.

The following comments from tenured faculty were noted: "The entire college faculty meets several times a year," and "Well, the whole faculty meets monthly."

The following comments were from non-tenured faculty: "We have an executive committee. We don't have any power." "We meet as a full faculty once a month to vote on curriculum and policy changes. When we ask questions, we are chastised by our VP for Academic Affairs, who runs the meetings and who controls discussion/debate."

Differing faculty perceptions on the institutional communication standard are best highlighted by some survey comments from tenured and non-tenured faculty. Tenured faculty who agreed that "the faculty as a whole has timely access to information necessary for faculty members to give input into governance processes," may be represented by this comment from a tenured faculty member: "We get this right in the major decisions, but some smaller decisions that come before faculty bodies do so without much background information."

However, non-tenured faculty members were more likely to disagree, as underscored by this comment: "Once again, faculty members are completely ignored when decisions are made 
on campus. Also, there is an incredible level of non-communication. This leads to speculation, rumors, and eventually the truth."

Additionally, non-tenured faculty members were more likely to indicate "I don't know" at a higher percentage rate compared to tenured faculty on 24 out of 26 questions. This includes perceptions on the role of the president, as underscored by this comment: "I don't know what our President really does. It all seems to be relegated to our Academic Affairs VP.”

Given the differences in perceptions about shared governance between tenured and nontenured faculty in this study, the results may lend credence to Gerber's (2010) assertion, as noted in the literature review, that the rise of contingent faculty appointments and the decline of tenuretrack faculty has a negative effect on faculty governance.

These RQ \#1 conclusions about differing perceptions have implications for practice and research that will be noted in later sections.

Research Question \#2 conclusion. What are administrators' perceptions of the climate for shared governance? Administrator respondents self-identified as "cabinet-level administrator" or "administrator." Cabinet-level administrators, regardless of title, serve on the president's cabinet at their respective institutions. Other administrators who do not serve on president's cabinet are considered "lower-level" administrators for purposes of this study.

Findings indicated that lower-level administrators and cabinet-level administrators responded similarly to the three survey items on institutional climate. A majority agreed that there was a culture of collegiality and respect, that negotiations were conducted in good faith and trust, and that the board supported the faculty's role in governance.

However, in a manner similar to the differences between tenured and non-tenured faculty, the findings indicated that there appeared to be some differences in perceptions between cabinet- 
level administrators compared to other lower-level administrators. Lower-level administrators were more likely to indicate "I don't know" to many of the other survey items at a response rate higher than $17 \%$, including both survey items on communication, two of three items regarding the role of the governing board, three out of four items on the role of the faculty, and four out of five items on structural arrangements. This suggested a general lack of understanding about key governance standards on the part of many lower-level administrators at their ACA institutions.

It should be noted that lower-level administrators represented the largest group of respondents (52) in the study. As noted in the literature review, Rhoades (2005) has suggested that an increase in non-faculty professionals in higher education has had a negative effect on governance. This rise in the number of managerial professionals may have resulted in a corresponding rise in the lack of understanding about the nature of shared governance and the appropriate roles of faculty, board, and administration.

Given the lack of knowledge of shared governance indicated, recommendations for practice and future research will be noted in a later section.

Research Question \#3 conclusion. What are staff members' perceptions of the climate for shared governance?

Findings indicated that on most of the seven governance standards, staff members chose "I don't know" on more items (23 out of 26) at a higher percentage than faculty or administrators, indicating a deficit of information about shared governance practices among many of the staff on their campuses in the Appalachian College Association.

While neither the AAUP nor AGB has outlined a role for staff members in the shared governance process, recent literature (Miller \& Murry, 2011) suggests that as the concept of 
shared governance continues to evolve, staff members should have a role in decision making in the academy. Implications for practice and research will be noted in later sections.

Research Question \#4 conclusion. The following conclusions are based upon a synthesis of the aggregated results of the perceptions of tenured and non-tenured faculty, administrators and cabinet-level administrators, and staff at participating Appalachian College Association schools. It should be noted that campus liaisons were requested to identify faculty, staff, and administrators as potential participants in the study who were participants in the shared governance processes at their respective institutions.

While the majority of respondents to survey items \#4, \#5, and \#11 on institutional climate indicated they agreed that there was collegiality and respect on their campuses, distinctions were drawn as noted in the following comments: "Yes, among many faculty. No, among administration and between administration and faculty." "Faculty are collegial with each other, but there is a great lack of collegiality with the academic administration. This appears to stem from a total lack of respect for the faculty by the academic administration." "It exists among the faculty and among the administration, but many members of our administration, including our VP for academic affairs, seem to have little respect for faculty. It is mixed when it comes to relations between faculty and staff."

Based on the number of responses indicating "I don't know" at $20 \%$ or higher on survey items \#8, \#10,\#15,\#17, \#18, \#29, \#22, \#23, \#24, \#25), there is a lack of knowledge about governance practices among faculty, administrators, and staff at some ACA institutions.

The conclusions for this research question have led to some recommendations for practice and future research. These will be noted in the following two sections.

\section{Recommendations for Practice}


A synthesis of conclusions from the four research questions yielded a number of recommendations to assist institutions in improving perceptions of the climate for shared governance. The recommendations are shown as bullet points and also include supporting rationale.

Advancing these practices assumes that there is an institutional commitment to shared governance and an acknowledgement of its value in academia. Burbules (2013) notes:

Shared governance begins with a presumption of shared commitment to the constitutional principles and to the best interests of the institution. Faculty and administrators view themselves as partners in a common project; this is what the 'shared' in shared governance means. (para. 9)

- Because most institutions know little about the experiences of part-time and contingent faculty (Kezar, Lester, \& Anderson, 2006), institutional research should focus attention on this group. Institutions should survey these faculty members on a range of issues, and include them in focus groups with vice presidents, deans, and department chairs in order to discern the most valuable ways to include them in governance processes and to ensure they are treated with respect.

While no empirical studies have actually demonstrated that shared governance has declined with the increase in contingent faculty, many higher education observers have suspected and feared the correlation, such as Gerber (2010), who asserts that this increase in contingent faculty and a decline in tenure-track faculty contributes to a decline in shared governance. In this study, the differences in perceptions between tenured and non-tenured faculty suggests that some non-tenured faculty feel marginalized in the governance process. 
Kezar, Lester, \& Anderson (2006) note, "Contingent faculty members still remain invisible on many campuses. Data will both inform our decisions and combat stereotypes" (p. 32). They also indicate that there has been no tradition or systematic policy for including contingent faculty in governance. Further, they propose that contingent and part-time faculty are "a valuable and underutilized resource that can contribute greatly to shared governance on college and university campuses" (p. 122), and that "campuses need to address biases and stereotypes that prevent contingent faculty from becoming valued members of the community" (p.131).

- Institutions should consider a very recent recommendation by the AAUP (2014) to define faculty inclusively rather than exclusively, ensuring that faculty status is not limited to those holding tenured or tenure-track appointments, and thereby promoting broader faculty participation in governance.

Ramo (1997) asserts that participation in governance is "an ethical obligation of faculty members," (p. 8), noting that "this helps ensure that the full diversity of available expertise will help shape the institution, prevents faculty governance from becoming a 'faculty oligarchy,' and sends a message to other stakeholders that all faculty are committed to furthering and supporting the quality of the academic enterprise." The literature does suggest that faculty members who play an active part in decision making have a much more favorable view of shared governance (Bok, 2013).

- Because of the significant change in faculty demographics, practice may also need to include the revision of policies and procedures to ensure contingent faculty are included in the governance process. 
Though many people inside and outside of higher education think of tenure-track appointments as the norm, in reality tenure-track faculty are a dwindling minority on American campuses. While in 1975 , tenure-track faculty accounted for $45.1 \%$ of the instructional staff, by 2009 they accounted for only 24.4\% (AAUP, 2012, para. 22).

The AAUP (2012) has also calculated that by 2009 — the latest year for which national data are available $-75.6 \%$ of US faculty appointments were off the tenure track and $60.5 \%$ of US faculty appointments were part-time appointments off the tenure track, including graduatestudent-employee appointments. These figures underrepresent postdoctoral fellows, a growing category of appointment on some campuses and in some disciplines.

- Institutions should consider adopting specific policies or practices that outline how faculty will be included in meetings of the governing board.

Very recently, the AAUP (2014) issued a statement on best practices for faculty communication and interaction with governing boards, as follows:

1) Every standing committee of the governing board, including the executive committee, should include a faculty representative.

2) New faculty representatives to the governing board should participate in orientation for new trustees.

3) Direct communication between the faculty and the governing board should occur through a liaison or conference committee consisting only of faculty members and trustees and meeting regularly to discuss topics of mutual interest. (para. 22)

- Some institutions would benefit from working collaboratively campus-wide on governance documents which define their own parameters for the decision making process, and broadly disseminating this information to campus 
constituents, including tenured and non-tenured faculty, as well as administrators and other staff members.

- Institutions should consider including lower-level administrators and staff members alongside others in efforts to educate and to develop common understanding of the shared governance process.

The findings of this ACA study indicated differences in perceptions between cabinet-level administrators and those lower-level administrators who do not serve on cabinet. Generally, as might be expected based on their participation in decision making at the institutional level and their typical engagement with the governing board, cabinet-level administrators generally seemed more informed about the standards of shared governance and more often inclined to have more positive perceptions. This parallels Bok's (2013) assertion that professors who "have an active part in shared governance have a much more favorable view" (p. 22).

Staff member respondents at ACA schools appeared least knowledgeable about governance, compared to faculty and administrators, as noted in the survey results. While AAUP's 1966 statement on shared governance did not include staff members, and the "shared governance compact" has traditionally been considered faculty, administration, and board (Bornstein, 2012, para. 8), Wellman (2006) cites an "ongoing evolution of the shared governance process" (p. 31) which increasingly includes staff members on many campuses.

According to Miller \& Murry (2011) the number of staff members at American higher education institutions has more than doubled in the past 20 years as occupations in technology, development, government relations, and even athletic administration have grown as never before in the history of the academy. The authors suggest that as the number, variety, and importance of 
these staff positions have grown, "so has the need for their involvement in determining the direction and vision of the contemporary university" (p. 3).

- Institutions should consider publishing a "statement on shared governance" as an outcome of a collaborative process that includes faculty, administrators, and staff. This might include a campus definition of the concept of shared governance, the principles upon which it is based, as well as roles and responsibilities.

More specifically, this could begin with a discussion about whether the institution's decision-making process is considered fully collaborative, consultative, or distributed (CHEPA, 2003).

- Board orientation for new members should include information on the historical context for shared governance in higher education, as well as the review of campus governance documents or statements on shared governance.

The findings of this study indicated that almost $60 \%$ of the faculty, administrators, and staff respondents at ACA schools did not know whether their board members were educated on matters of shared governance, and more than $20 \%$ disagreed that the board was so informed. For this reason it seems that board members would benefit from understanding the historical context of collegial decision making, especially given that the literature indicates they increasingly come to higher education from the world of business (Bornstein, 2012).

- Governing boards should include a regular assessment of their membership to gauge background and experience as a means of ensuring that some board members have an understanding of higher education and shared governance. As suggested by Bornstein (2012), boards can improve their understanding of shared 
governance by ensuring that their membership includes educators from other institutions and associations who bring a broad understanding of higher education and institutional governance.

- To help shared governance work, the president must assume the lead in making the concept of shared governance a part of board orientation.

Bornstein (2012) noted:

Most board members come from a business culture and are unfamiliar with these core concepts, which may seem to them unnecessary, disruptive, and unreasonable. The president is in the best position to promote contact, cooperation, and consensus among board members, administrators, and faculty members by creating opportunities for interaction and consultation. (para. 24)

- Institutions would benefit from regularly conducting assessments of their campus decision-making processes, including a broad array of campus constituents, as well as board members.

This practice would provide an opportunity to inform, as well as evaluate. Olson (2009) notes:

The key to genuine shared governance is broad and unending communication. When various groups of people are kept in the loop and understand what developments are occurring within the university, and when they are invited to participate as true partners, the institution prospers. That, after all, is our common goal. (para. 14)

In addition to improving the climate for governance in these various ways, it is expected that institutions will realize the benefits of shared governance as noted in the literature reviewmore complex analysis and better decisions, greater buy-in and trust, and improved morale (Birnbaum, 1992; Bensimon \& Neumann, 1993; Ferren \& Stanton, 2004: Kezar, Carducci \& Contreras-McGavin, 2006). 


\section{Recommendations for Future Research}

- Given the ongoing debate about more "corporate" models of governance versus the traditional, "consensual" academic approaches as noted in the literature review, research is needed to identify and study institutions which have instituted a more corporate approach to determine the impact of such decision-making processes on institutional effectiveness.

- Qualitative studies that include opportunities to interview faculty, administrators, and board members on campuses where the climate for governance is sound would provide rich data about best practices in shared governance, adding to the literature and providing practical assistance for institutions of higher education.

This study focused on perceptions of shared governance at Appalachian College Association institutions. However, because the data is aggregated, there is no opportunity to identify individual institutions where the climate for governance is sound, and from which best practices for effectively implementing shared governance could be gleaned.

In her article, "Transforming Institutions through Shared Governance," president emerita Rita Bornstein (2012) affirms the need for understanding the effective implementation of shared governance:

Shared governance is a basic tenet of higher education and is frequently referred

to. But what, at its best, does shared governance mean in today's changing environment?

How can institutions most effectively implement shared governance, and what is the specific role of the board, as well as of the president and faculty members, in doing so? (para.3) 
- More research is needed on the role and effectiveness of governing boards.

Bok (2013) says, "One essential part of any careful assessment of campus governance is how well it has responded to the most important challenges facing colleges and universities" (para. 12). He asserts that the governing board could and should have an increased role.

Research is needed to determine how that role might change compared to the traditional concept outlined in the literature.

The results of this study suggested that the role and practices of the governing board in shared governance remains unclear on many ACA campuses. A recent article by Derek Bok (2013) asserts that "few boards have been notably successful in helping to shape the goals and priorities of their institutions" (p. 22), and notes that this is an inadequate approach to meeting some of the key challenges facing higher education today.

\section{Conclusion}

Olson's (2009) assertion on the nature of shared governance seems to underscore its inherent challenges:

Shared governance is not a simple matter of committee consensus.... or any number of other common misconceptions. Shared governance is much more complex; it is a delicate balance between faculty and staff participation in planning and decision-making processes, on the one hand, and administrative accountability on the other. (para. 6) Broad participation, collaboration, and compromise are the mechanisms by which colleges and universities have traditionally governed themselves. Shared governance builds social capital in a college or university-relationships of trust, cooperation, and reciprocity that enable an institution to fulfill its goals (Bornstein, 2012). 
Astin \& Astin (2000) have noted that when the individual is a member of a collaborative group that has identified a shared purpose, it is much easier to behave with authenticity. Collaboration with a shared purpose also enhances the individual's commitment because it serves as a reinforcer: like-minded people working together toward a common goal strengthen each other's individual commitment toward that goal.

In the increasingly competitive and ever-changing higher education setting, it is incumbent upon institutions of higher education to avail themselves of best practices in all areas of academe, including shared governance. While shared governance is a term used primarily in higher education, the underlying concept represents good management practice in many settings (Bornstein, 2012).

Charles C. Krulak, who assumed the presidency of Birmingham Southern College in 2011 after a distinguished career in the military and in business, wrote about his introduction to the basic AAUP documents on shared governance (2011):

"I found them in sync with the way I have operated for years," he said. "I have yet to find a truly successful military leader, business leader, or professional coach who did not seek out the unvarnished opinions and views of his or her people. Not only seek out opinions and views but critically understand that it is bad business to ask people to charge a machine gun nest or cut a business deal or accept a game plan without fully understanding their views of the proposed tactics and getting their buy-in” (para. 4).

"A commitment to shared governance improves the productivity, quality, and reputation of an institution and creates a positive climate for students, staff members, and the community" (Bornstein, 2012, Conclusion). To that end, institutions committed to shared governance would do well to focus on collaborative processes to develop a common understanding of its meaning 
and value, broadly disseminate this information to its campus and its board, and include contingent and non-tenured faculty in the decision-making process.

\section{References}

Alvarado, K., Boblin-Cummings, S., \& Goddard, P. (2000). Experiencing nursing governance: Developing a post merger nursing committee structure. Canadian Journal of Nursing Leadership, 13(4), 30-35. 
American Association of University Professors. (n.d.). Informal glossary of AAUP terms and abbreviations. Retrieved from http://www.aaup.org/AAUP/about/mission/glossary.htm American Association of University Professors (1966). Statement on government of colleges and Universities. Retrieved from http://www.aaup.org/AAUP/pubsres/policydocs/contents/governancestatement.htm American Association of University Professors (1994, Jul.-Aug.). On the relationship of faculty governance to academic freedom. Academe, 80(4), 47-49. New York, NY: AAUP.

American Association of University Professors. (2006). Statement on government of colleges and universities (1966). In Policy documents and reports (10 ${ }^{\text {th }}$ edition), 135-140. Baltimore: Johns Hopkins University Press.

American Association of University Professors. (2013). The inclusion in governance of faculty members holding contingent appointments. Retrieved from http://www.aaup.org/report/governance-inclusion

American Association of University Professors. (2014). Faculty communication with governing boards: Best practices. Retrieved from http://www.aaup.org/report/faculty-communication-governing-boards-best-practices American Federation of Teachers. (2006). Shared governance in colleges and universities: A statement of the higher education program policy council. Retrieved from http://www.fccc.suny.edu/governance/sharedGovernance0806.pdf Anthony, M. (2004). Shared governance models: The theory, practice, and evidence. Online Journal of Issues in Nursing, 9(1), pp. 25-43. Retrieved from www.nursingworld.org/MainMenuCategories/ANAMarketplace/ANAPeriodicals/OJIN/T ableofContents/Volume92004/No1Jan04/SharedGovernanceModels.aspx 
Association of Governing Boards of Universities and Colleges. (1996). Renewing the academic presidency: Stronger leadership for tougher times. Washington DC: Association of Governing Boards.

Association of Governing Boards of Universities and Colleges. (2001). AGB statement on institutional governance and governing in the public trust: External influences on colleges and universities.

Association of Governing Boards of Universities and Colleges (2006). The leadership imperative. Retrieved from http://www.agb.org/system/files/u5/imperative.pdf

Association of Governing Boards of Universities and Colleges. (2009a). Faculty, governing boards and institutional governance. Retrieved from http://agb.org/sites/agb.org/files/u16/FacultyGoverning\%20BoardsandInstitutionalGover nance_final.pdf

Association of Governing Boards of Universities and Colleges. (2009b). The AGB survey of higher education governance. Retrieved from http://www.agb.org/reports/2009/agb-survey-higher-education-governancel Association of Governing Boards of Universities and Colleges. (2009c). Effective governing boards: A guide for members of governing boards of independent colleges and universities. Washington, DC: Association of Governing Boards of Universities and Colleges.

Association of Governing Boards of Universities and Colleges. (2010a). Policies, practices, and composition of governing boards of independent colleges and universities. Retrieved from 
http://www.agb.org/sites/agb.org/files/u3/2010IndependentBoardCompositionSurvey\%20 Summary.pdf

Association of Governing Boards of Universities and Colleges. (2010b). Statement on board responsibility for institutional governance. Retrieved from http://www.agb.org/sites/agb.org/files/u3/Statement\%20on\%20Institutional\%20Governa nce.pdf

Association of Governing Boards of Universities and Colleges. (2012). The 2012 AGB Survey of Higher Education Governance. Retrieved from http://agb.org/sites/agb.org/files/u3821/AGBGovSurvey2012Full.pdf

Astin, A.W., \& Astin, H. W. (2000). Leadership reconsidered: Engaging higher education in social change. Battle Creek, MI: Kellogg Foundation.

Bensimon, E. M., \& Neumann, A. (1993). Redesigning collegiate leadership: Teams and teamwork in higher education. Baltimore: The Johns Hopkins University Press.

Birnbaum, R. (1988). How colleges work: The cybernetics of academic organization and leadership. San Francisco: Jossey-Bass.

Birnbaum, R. (1992). How academic leadership works: Understanding success and failure in the academic presidency. San Francisco: Jossey-Bass.

Birnbaum, R. (2003). The end of shared governance: Looking ahead or looking back. Opinion paper prepared by the Center for Higher Education Policy Analysis. Retrieved from http://www.usc.edu/dept/chepa/gov/roundtable2003/birnbaum.pdf

Bok, D. (2013). The trouble with shared governance. Trusteeship, 21(5). Retrieved from http://agb.org/trusteeship/2013/9/trouble-shared-governance

Bornstein, R. (2012). Transforming institutions through shared governance. 
Trusteeship, 20(5). Retrieved from http://agb.org/trusteeship/2012/9/transforminginstitutions-through-shared-governance

Brown, M. C. (Ed.). (2000). Organization \& governance in higher education.

Boston, MA: Pearson Custom Publishing.

Brubacher, J. S., \& Rudy, W. (1997). Higher education in transition: A history of American colleges and universities. New Brunswick, NJ: Transaction Publishers.

Burbules, N. C. (2013). How unions weaken shared governance.

The Chronicle of Higher Education. http://chronicle.com/article/How-Unions-WeakenShared/142625/

Center for Higher Education Policy Analysis. (2003). Challenges for governance: A national report. Retrieved from http://www.usc.edu/dept/chepa/pdf/gov_monograph03.pdf

Cohen, M. D., \& March, J. G. (1974). Leadership and ambiguity. Boston: Harvard Business School Press.

Creswell, J. W. (2003). Research design: Qualitative, quantitative and mixed methods approaches. Thousand Oaks, CA: Sage Publications.

Dillman, D.A., Smyth, J.D., \& Christian, L.M. (2009). Internet, mail, and mixed-mode surveys: The tailored design method (3rd ed.). Hoboken, NJ: John Wiley \& Sons, Inc.

Eckel, P.D., \& Kezar, A.J., (2003). Taking the reins: Institutional transformation in higher education. Westport, CT: Praeger Publishers.

Eckel, P.D., \& Kezar, A.J. (2011). Presidents leading: The dynamics and complexities of campus leadership. In P.G. Altbach, P.J. Gumport, R.O. Berdahl (Eds.), American higher education in the twenty-first century: Social, political, and economic challenges (3rd ed.) (pp. 279-311). Baltimore, MD: The John Hopkins University Press. 
El-Khawas, E. 1995. Where is the faculty voice in recent academic decisions? Tertiary Education and Management 1(1), 31-35.

Etzioni, A. 1964. Modern Organizations. Englewood Cliffs, NJ: Prentice-Hall, Inc.

Evan, K., Aubry, K., Hawkins, M., Curley, T.A., \& Porter-O’Grady, T. (1995). Whole systems shared governance: A model for the integrated health system. Journal of Nursing Administration, 25(5), 18-27.

Ferren, A.S., \& Stanton, W. W. (2004). Leadership through collaboration: The role of the chief academic officer. Westport, CT: Praeger Publishers.

Field, A. (2009). Discovering statistics using SPSS (3rd ed.). Thousand Oaks, CA: Sage.

Firkin, M.W., \& Post, R. C. (2009). For the common good: Principles of American academic freedom. Connecticut: Yale University Press.

Gerber, L. G. (2001). Inextricably linked: Shared governance and academic freedom. Academe Online. Retrieved from http://aaup.org/AAUP/pubsres/academe/2001/MJ/Feat/gerb.htm

Gerber, L. G. (2010). Professionalization as the basis for academic freedom and faculty governance. AAUP Journal of Academic Freedom. Retrieved from http://www.academicfreedomjournal.org/VolumeOne/Gerber.pdf

Gumport, P. J. (1993). The contested terrain of academic program reduction. Journal of Higher Education, 64(3), pp. 283-311.

Gumport, P. J. (2001). Divided we govern? Peer Review. American Association of Colleges and Universities. Retrieved from http://www.aacu.org/peerreview/pr-sp01/pr-sp01feature1.cfm 
Hammond, T. H. (2004). Herding cats in university hierarchies: Formal structure and policy choice in American research universities. In R. G. Ehrenberg (Ed.), Governing academia (pp. 91-138). Ithaca, NY: Cornell University Press.

Haskell, T. L. (1998). Justifying the rights of academic freedom in the era of power/knowledge. In L. Menand (Ed.), The future of academic freedom (pp. 43-90). Chicago: The University of Chicago Press.

Hek, G. \& Moule, P. (2006). Making sense of research: An introduction for health and social care practitioners (3rd ed.). Thousand Oaks, CA: Sage Publications.

Hermalin, B. E. (2004.) Higher education boards of trustees. In R. G. Ehrenberg (Ed.) Governing academia (pp. 28-48). Ithaca, NY: Cornell University Press.

Hodson, J. B. (2010, Spring). Leading the way: The role of presidents and academic deans in fund-raising. New Directions for Higher Education, 149, pp. 23-42. doi: 10.1002/he.379

Iarossi, G. (2006). The power of survey design. Washington, DC: The World Bank.

Ingram, R. T. (1994). Governing independent colleges and universities: A handbook for trustees, chief executives, and other campus leaders. San Francisco: Jossey-Bass.

Keller, G. (2001). Governance: The remarkable ambiguity. In, P. Altbach, P. J. Gumport, \& D. B. Johnstone, (Eds.), In defense of the American university. Baltimore: Johns Hopkins University Press.

Kerr, C. (1994). Higher education cannot escape history: Issues for the $21^{\text {st }}$ century. Albany: State University of New York Press.

Kezar, A. J. (Ed.). (2009). Rethinking leadership practices in a complex, multicultural, and Global environment: New concepts and models for higher education. Sterling, VA: Stylus Publishing. 
Kezar, A. J., Carducci, R., \& Contreras-McGavin, M. (2006). Rethinking the L word in higher education: The revolution in research on leadership. Las Vegas, NV: ASHE.

Kezar, A. J., Lester, J., \& Anderson, G. (2006). Challenging stereotypes that interfere with effective governance. Thought and Action, 121-134.

Kirp, D. L. (2003). Shakespeare, Einstein, and the bottom line: The marketing of higher education. Cambridge,MA: Harvard University Press.

Knapp, J. C., \& Siegel, D. J. (Eds.) 2009. The business of higher education. San Francisco: Praeger.

Krulak, C. (2011). Commandant to president. Inside Higher Ed. Retrieved from http://www.insidehighered.com/advice/2011/10/05/essay_on_moving_from_the_military _to_a_college_presidency

Leach, W. D. (2008). Shared governance in higher education: Structural and cultural responses to a changing national climate. Center for Collaborative Policy. Sacramento, CA: California State University.

Lucas, C.J. (1994). American higher education: A history. New York: St. Martin’s Press.

Menand, L.(1998). The limits of academic freedom. In L. Menand (Ed.), The future of academic freedom (pp. 3-20). Chicago, IL: The University of Chicago Press.

Miller, M. T. \& Murry, J.W., Jr. (Eds.) (2011). Staff governance and institutional policy formation. Greenwich, CT: Information Age Publishing.

Morphew, C. (1999). Challenges facing shared governance within the college. New Directions for Higher Education, 24, pp. 71-79. San Francisco, CA: Jossey-Bass.

Mortimer, K.P., \& McConnell, T.R. (1978). Sharing authority effectively. San Francisco: 
Jossey Bass.

Mortimer, K.P., \& Sathre, C.O. (2007). The art and politics of academic governance:

Relations among boards, presidents, and faculty. Westport, CT: Praeger Publishers.

Newman, F., Couturier, L., \& Scurry, J. (2004). The future of higher education:

Rhetoric, reality, and the risks of the market. San Francisco: Jossey-Bass.

Olson, G. A. (2009). Exactly what is 'shared governance'? The Chronicle of Higher Education. Retrieved from http://chronicle.com/article/Exactly-What-Is-Shared/47065/

Patton, M. Q. (2002). Qualitative research and evaluation methods. Thousand Oaks, CA: Sage Publications.

Peterson, M. W., \& Spencer, M. G. (1991). Understanding academic culture and climate.

In M. W. Peterson (Ed.) Organization and governance in higher education. MI: Ginn Press.

Pierce, S. R. (2012). On being presidential. San Francisco, CA: Jossey-Bass.

Ramo, K. (1997). Assessing the faculty's role in shared governance: Implications of AAUP standards. Washington, DC: AAUP.

Rashdall, H. (1936). The Universities of Europe in the Middle Ages, ed. Frederick M. Powiche and A.B. Emden, 3 vols. London: Oxford University Press.

Rhoades, G. (2005, May/June). Capitalism, academic style and shared governance. Academe Online. Retrieved from http://aaup.org/AAUP/CMS_Templates/AcademeTemplates/AcademeArticle.aspx?NRM ODE $=$ Published\&NRNODEGUID $=\{$ AF095360-8B45-46D4-BF001234E2C178DA $\} \&$ NRORIGINALURL=\%2FAAUP\%2Fpubsres $\% 2$ Facademe $\% 2 F 2005$ \%2FMJ\%2FFeat\%2Frhod.htm\&NRCACHEHINT=NoModifyGu 
Rice, E. R., \& Austin, A. E. (1991). High faculty morale: What exemplary colleges do right. In M. W. Peterson (Ed.), Organization and governance in higher education (pp. 16-35). MI: Ginn Press.

Rosser, V. J. (2002). Governance. In J. F. Forest \& K. Kinser (Eds.), Higher education in the United States: An encyclopedia (pp. 279-284). Santa Barbara: ABC-CLIO.

Rosser, V. J. (2003). Historical overview of faculty governance in higher education. In M. Miller \& J. Caplow (Eds.), Policy and university faculty governance (pp. 3-25). Greenwood, CT: Praeger Publishers.

Sapsford, R. (2007). Survey research (2nd ed.). Thousand Oaks, CA: Sage Publications.

Schuster, J. H., Smith, D. G., Corak, K. A., \& Yamada, M. M. (1994). Strategic governance: How to make big decisions better. Phoenix, AZ: Oryx Press.

Schwartz, M., Skinner, R., \& Bowen, Z. (2009). Faculty, governing boards, and institutional governance. New York, NY: TIAA-CREF Institute.

Smith, C.V. (2009). The decline of shared governance in higher education. KCKCC e-Journal. Retrieved from http://www.kckcc.edu/ejournal/archives/october2009/article/theDeclineOfSharedGoverna nceinHigherEducation.aspx

Spitzberg, I. J. (1989). Governance and aspiration: Leading the diversity of higher education. In J. Schuster and L. H. Miller (Eds.), Governing tomorrow's campus: Perspectives and agendas (pp. 33-65). MI: American Council on Education.

Suskie, L. A. (1996, $2^{\text {nd }}$ Ed). Questionnaire survey research: What works. Tallahassee, FL: The Association for Institutional Research.

Tanner, T., \& Palfreyman, D. (2010). The collegial tradition in the age of mass higher 
education. New York: Springer.

Thelin, J. R. (2004). A history of American higher education. Baltimore, MD.: The Johns Hopkins UniversityPress.

Tierney, W. G. (1988). Organizational culture in higher education: Defining the essentials. The Journal of Higher Education, 59(1), 2-21.

Tierney, W.G., \& Minor, J.T. (2003). Challenges for governance: A national report.

Los Angeles: CA. Center for Higher Education Policy Analysis.

Retrieved from

http://www.usc.edu/dept/chepa/pdf/gov_monograph03.pdf

Tierney, W.G. (2004a). Improving academic governance: Utilizing a cultural framework to improve organizational performance. In W. G. Tierney (Ed.), Competing conceptions of academic governance: Negotiating the perfect storm (pp. 66-82). Baltimore, MD: The Johns Hopkins University Press.

Tierney, W.G. (2004b). Competing Conceptions of Academic Governance: Negotiating the Perfect Storm, Baltimore, MD: Johns Hopkins University Press.

Tierney, W.G. (Ed.). (2006). Governance and the Public Good. Albany, NY: State University of New York Press.

Tierney, W.G., \& Lechuga, V. M. (2004). Restructuring Shared Governance in Higher Education, San Francisco, CA.: Jossey-Bass.

Wellman, J.A. (2006). Rethinking state governance of higher education. In W. G. Tierney (Ed.), Governance and the public good (pp. 51-72). Albany, NY: State University of New York Press.

Zemsky. R. (2009). Making reform work: The case for transforming American higher Education. New Brunswick, NJ: Rutgers University Press. 


\section{APPENDIX A: Survey Instrument}

As a doctoral student at West Virginia University majoring in higher education administration, I request your participation in my research study entitled, A Study of Faculty, Administrative, and Staff Perceptions of the Climate for Shared Governance at Appalachian College Association Member Institutions.

Your answers to the following survey questions will be anonymous, and your institution's 
participation in this study will remain confidential. The information that will be obtained from this survey will be reported in the aggregate. Your name and any other identifiable information about you or your institution will not be released in the reported results. You must be 18 years or older to participate, and your participation is entirely voluntary.

In addition, you can skip questions or exit the questionnaire at any time. Please answer as candidly as possible.

Thank you for being willing to participate in the survey.

--Tanya Easton

Doctoral Student

West Virginia University

Demographic Items

Please indicate the appropriate responses to the following [drop-down menu or list of choices]:

1. I am a

male

female.

2. I am (choose all that apply):

tenured faculty member

nontenured faculty member

staff member

cabinet-level administrator

administrator.

3. I have been employed in higher education for (range of years):

Less than 1 year

1-5 years

6-10 years

11-15 years

$16-20$ years

21-25 years 
26-30 years

more than 30 years

\section{Shared Governance Items}

Please respond by indicating your agreement or disagreement with the following statements about your institution's decision-making and shared governance processes:

4. There is an atmosphere of collegiality and respect on our campus.

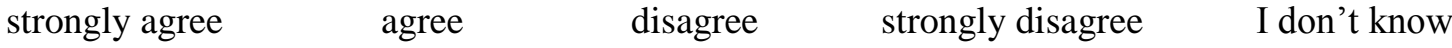

Comment:

5. Negotiations among campus constituents are open and carried out in good faith and an atmosphere of trust.

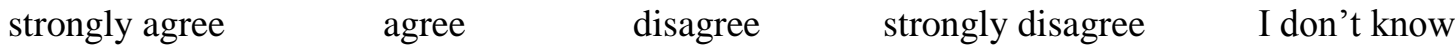

Comment:

6. There is a process for consultation with faculty leadership.

strongly agree $\quad$ agree $\quad$ disagree strongly disagree I don't know

Comment:

7. In addition to faculty representatives, the faculty as a whole has timely access to information necessary for faculty members to give input into governance processes.

$\begin{array}{llll}\text { strongly agree } & \text { agree } & \text { disagree } & \text { strongly disagree }\end{array}$

Comment: 
8. Members of the governing board have appropriate individual qualifications with regard to education and experience.

$\begin{array}{llll}\text { strongly agree } & \text { agree } & \text { disagree } & \text { strongly disagree }\end{array}$

Comment:

9. Board members are not involved in the day-to-day operations of the institution.

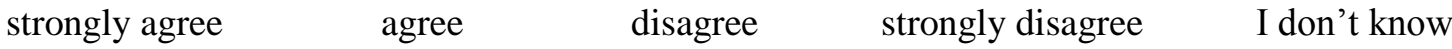

Comment:

10. Board members inform themselves on governance issues by keeping up with the literature and participating in training opportunities and meetings of the Association of Governing Boards, the AAUP, or similar organizations.

strongly agree $\quad$ agree $\quad$ disagree strongly disagree I don't know

Comment:

11. The board respects and supports the faculty's traditional role in institutional governance.

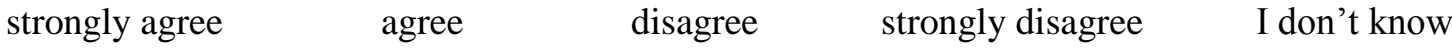

Comment:

12. The president has adequate academic as well as administrative credentials to serve as the chief executive officer of the institution.

$\begin{array}{llll}\text { strongly agree } & \text { agree } & \text { disagree } & \text { strongly disagree }\end{array}$

Comment:

13. The president rarely overturns faculty decisions and recommendations in areas in which the faculty has primary responsibility (e.g., curriculum, tenure, and promotion decisions).

$\begin{array}{llll}\text { strongly agree } & \text { agree } & \text { disagree } & \text { strongly disagree }\end{array}$

Comment: 
14. The president seeks faculty input on matters that are his or her primary responsibility (such as budgeting) in which the faculty has an appropriate interest but not primary responsibility.

strongly agree

agree

disagree

strongly disagree

I don't know

Comment:

15. The president effectively advocates the principles of shared governance to the governing board. $\begin{array}{llll}\text { strongly agree } & \text { agree } & \text { disagree } & \text { strongly disagree }\end{array}$ Comment:

16. The faculty is afforded an appropriate degree of autonomy with regard to its areas of primary responsibility (curriculum, tenure, and promotion) by the administration and governing board.

strongly agree agree disagree strongly disagree don't know

Comment:

17. The faculty appropriately exercises its capacity for both adverse and positive decisions in faculty personnel matters.

strongly agree $\quad$ agree $\quad$ disagree strongly disagree I don't know

Comment:

18. Resources for faculty development, reward structures, and workloads support the development of faculty expertise in shared governance.

$\begin{array}{llll}\text { strongly agree } & \text { agree } & \text { disagree } & \text { strongly disagree }\end{array}$

Comment:

19. There is joint responsibility for decision-making in the area of long-range planning. 
strongly agree

agree

disagree

strongly disagree

I don't know

Comment:

20. There is joint responsibility for decision-making regarding existing or prospective physical resources.

$\begin{array}{llll}\text { strongly agree } & \text { agree } & \text { disagree } & \text { strongly disagree }\end{array}$

Comment:

21. There is joint responsibility for decision-making in institutional budgeting. strongly agree $\quad$ agree disagree strongly disagree I don't know Comment:

22. There is joint responsibility for decision-making in the selection of a new president. strongly agree $\quad$ agree $\quad$ disagree strongly disagree I don't know Comment:

23. There is joint responsibility for decision-making in faculty selection and promotion and the granting of tenure.
strongly agree
agree
disagree
strongly disagree
I don't know

Comment:

24. The structures and processes that allow for faculty collaboration are clearly defined in governance documents.

strongly agree $\quad$ agree $\quad$ disagree $\quad$ strongly disagree $\quad$ I don't know

Comment: 
25. These collaborative structures and processes are functioning in an effective manner.

strongly agree $\quad$ agree $\quad$ disagree strongly disagree I don't know

Comment:

26. Our institution does not have a faculty senate or other institution-wide governance body that meets on a regular basis.

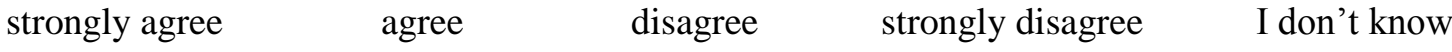

Comment:

27. Faculty members determine how their own representatives are selected to the senate/faculty governing body.

$\begin{array}{llll}\text { strongly agree } & \text { agree } & \text { disagree } & \text { strongly disagree }\end{array}$

Comment:

28. For joint committees on which the faculty is represented, the representation appropriately reflects the degree of the faculty's stake in the issue or area the committee is charged with addressing.

$\begin{array}{llll}\text { strongly agree } & \text { agree } & \text { disagree } & \text { strongly disagree }\end{array}$

Comment:

29. The faculty as a whole has an opportunity to meet and comment on "short-listed" academic administrative candidates before hiring decisions are made.

strongly agree $\quad$ agree $\quad$ disagree strongly disagree I don't know

Comment: 
APPENDIX B: Approval Letter from Appalachian College Association 


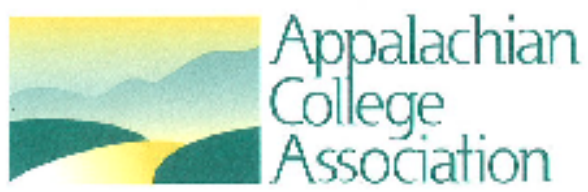

March 30,2012

Ms. Tanya Shelton

RR 2, Box $237 \mathrm{~A}$

Graton. W 2635

Dear Ms. Shelton:

This [etter scrves as approve] for you to conduct your qualitative study on shared governance through the Appalachian College Asoociatiun, As such, you may cunlacl the ataklemic deanis ankl presitlents al ewth instilution tn seek their patrticipulior.

My andersanding is that the first step would be conducting a survey of sclected faculty members

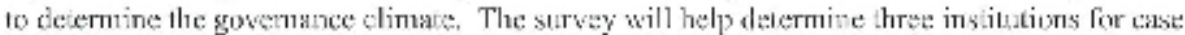
slutly interviews. Appropriale comlitentizlity and anonymity pratecols will be maintained throughout the study, with IRB permission from WVU and the participating instimtions as requited.

We likek forwart to recoiving the resul sx of your study.

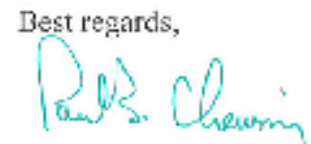

Dr. Paul Chewritag

President

Appalachian Collogo Association

310 C'enter Street - Berea, KY 19103

Ph: $85 y .486 .45^{8} \cdot$ Px: $859-486.9519 \cdot$ acaweb.org

\section{APPENDIX C: Approval Letter from WVU IRB}




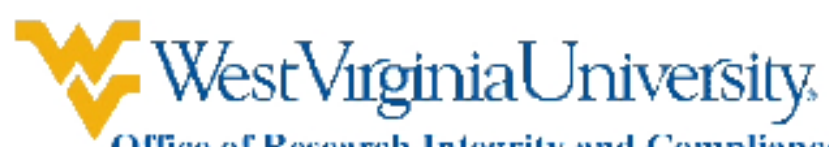

Orlice of Research Integrity and Compliance

\section{Acknowledgement Letter Exempt Initial Protocol Review}

To

From

Approval Period

Subject

Protocol Tracking

Title
Richard Walls

WVU Office of Research Integrity and Compliance

09/18/2013 Expiration Date 09/17/2016

Acknowledgement Letter Exempt Initial Protocol Reriew

1302021233

A Study of Faculty, Administrative, and Staff Perceptions of the Climate for Shared Governance at Appalachian College Association Member Institutions

The above-referenced study was reviewed by the West Virginia University Institutional Review Board IRB and was granted exemption in accordance with 45 CFR 46.101.

- This research study was granted an exemption because the Research involves educational tests, survey procedures, interview procedures or observation of public behavior and (i) information obtained is recorded in such a manner that human subjects cannot be identified, directly or through identifiers linked to the subjects; and (ii) any disclosure of the human subjects responses outside the research could not reasonably place the subjects at risk of criminal or civil liability or be damaging to the subjects financial standing, employability, or reputation [45 CFR 46.101(2)]. All exemptions are only good for three years. If this research extends more than three years beyond the approved date, then the researcher will have to request another exemption. The following documents have been acknowledged for use in this study and are available in the WVU+kc system:

Documents for use in this study have been acknowledged and validated and are available in the WVUkc system in the Notes and Attachments section of your protocol.

If you have any questions, please contact the IRB at 3042937073.

Thank you.

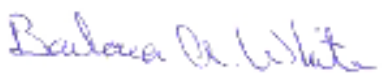

Board Designee Barbara White 


\section{APPENDIX D: Introduction of Research Study by ACA President (To ACA Member Institution Presidents and Vice Presidents for Academic Affairs)}

This letter serves as an introduction and a request that your institution consider participating in a study on shared governance conducted by a doctoral student at West Virginia University. It is a timely topic. The study is intended to enhance the knowledge on the climate for shared governance at Appalachian College Association institutions.

The data collection will be done via an online survey to selected faculty, administrators, and staff at all ACA institutions. The results of the study will be used specifically for the dissertation, with aggregated survey results. The researcher will preserve the anonymity of survey respondents and maintain confidentiality about participating institutions.

Soon you will receive an e-mail from the doctoral student, Tanya Easton, requesting that your institution participate in the study by allowing a survey of faculty, administrators, and staff who participate in decision making and shared governance at your institution. The survey is not intended to gauge satisfaction or opinion, but to identify observable conditions relative to the climate for shared governance.

In the letter from Mrs. Easton, you will be asked to affirm your participation with a return e-mail response. With your assistance, a campus liaison will then be identified and asked to assist with identifying appropriate faculty, administrators, and staff to receive the survey.

The results of the doctoral study will be shared with you in an executive summary, should you choose to participate. I appreciate your consideration of this request, especially given the constraints of time and resources within which we all operate.

Sincerely,

Paul Chemening

Dr. Paul Chewning

President

Appalachian College Association 


\section{APPENDIX E: Request for Approval to Conduct Research Study (To ACA Presidents and Provosts)}

Dear Presidents and Provosts of ACA Member Schools:

This serves as a follow-up to an introductory e-mail you recently received from Dr. Paul Chewning, president of the Appalachian College Association, regarding my doctoral study entitled A Study of Administrative, Faculty and Staff Perceptions of the Climate for Shared Governance at Appalachian College Association Member Institutions, intended to contribute to the literature on higher education administration and serve as a springboard for future research.

I respectfully request your permission to survey faculty members, administrators, and staff at your institution who have a role in decision making and shared governance, and ask that you provide me with the name of the campus liaison or administrative assistant with whom I may work to obtain their names.

To comply with Human Subjects Exemption Review from West Virginia University's Institutional Review Board, I am required to submit approval granting permission for me to conduct research at your institution. If you are willing to grant me permission, please hit REPLY and indicate your approval and the name of an appropriate campus liaison or administrative assistant with whom I may proceed.

The brief survey is comprised of a series of questions initially developed by the American Association of University Professors (AAUP) as a means by which to gauge the climate for governance at higher education institutions. It is intended to reflect observable conditions, not to gauge satisfaction or opinion.

I want to assure you that the results of this study will be used specifically for my dissertation, and that I will maintain confidentiality of the aggregated data and preserve the anonymity of the survey respondents, as well as the confidentiality of the individual participating institutions. It will also be made clear to all participants at your institution that their involvement in this project is entirely voluntary. Because the results of this study may contain information that could be of interest to you, I will gladly share an executive summary of the study with you or any of the participants upon request.

Should you have any questions or concerns regarding this process, please feel free to contact me at 202-870-8513 or via email at eastont@ cua.edu. Many thanks for your consideration.

Sincerely,

Tanya L. Eastan

Tanya L. Easton, M.A. 
Doctoral Student

West Virginia University

\section{APPENDIX F: Reminder Request for Approval to Conduct Study (To ACA Presidents and Provosts)}

I would be pleased to have your institution's participation in my research study as outlined in the email below I sent on November 14. Many thanks for your consideration of this final request. Best wishes to you for the holidays and the new year. - Tanya Easton

Dear Presidents and Provosts of ACA Member Schools:

This serves as a follow-up to an introductory letter you recently received from Dr. Paul Chewning, president of the Appalachian College Association, regarding my doctoral study entitled A Study of Administrative, Faculty and Staff Perceptions of the Climate for Shared Governance at Appalachian College Association Member Institutions, intended to contribute to the literature on higher education administration and serve as a springboard for future research.

I respectfully request your permission to survey faculty members, administrators, and staff at your institution who have a role in decision making and shared governance, and ask that you provide me with the name of the campus liaison or administrative assistant with whom I may work to obtain their names.

\section{To comply with Human Subjects Exemption Review from West Virginia University's} Institutional Review Board, I am required to submit approval granting permission for me to conduct research at your institution. If you are willing to grant me permission, please hit REPLY and indicate your approval and the name of an appropriate campus liaison or administrative assistant with whom I may proceed.

The brief survey is comprised of a series of questions initially developed by the American Association of University Professors (AAUP) as a means by which to gauge the climate for governance at higher education institutions. It is intended to reflect observable conditions, not to gauge satisfaction or opinion.

I want to assure you that the results of this study will be used specifically for my dissertation, and that I will maintain confidentiality of the aggregated data and preserve the anonymity of the survey respondents, as well as the confidentiality of the individual participating institutions. It will also be made clear to all participants at your institution that their involvement in this project is entirely voluntary. Because the results of this study may contain information that could be of interest to you, I will gladly share an executive summary of the study with you or any of the participants upon request. 
Should you have any questions or concerns regarding this process, please feel free to contact me at 202-870-8513 or via email at eastont@ cua.edu. Many thanks for your consideration.

Sincerely,

Tanya L. Eastan

Doctoral Student

West Virginia University

\section{APPENDIX G: Request for Individual Participation in Research Study w SurveyLink (To Selected ACA Faculty, Administrators, and Staff)}

As a doctoral student at West Virginia University majoring in higher education administration, I request your participation in my research study entitled, A Study of Administrative, Faculty, and Staff Perceptions of the Climate for Shared Governance at Appalachian College Association Member Institutions. Dr. Richard Walls is serving as the Principal Investigator of this study, which is on file with the West Virginia University Institutional Review Board. The purpose of this e-mail is to request your participation in a brief online survey as part of this study.

I have received approval from your president to conduct this study on your campus. Your answers to survey questions will be anonymous, and your institution's participation in this study will remain confidential. The information that will be obtained from this survey will be reported in the aggregate. Your name and any other identifiable information about you or your institution will not be released in the reported results. You must be 18 years or older to participate, and your participation is entirely voluntary. In addition, you can skip questions or exit the questionnaire at any time.

Please note that there are no known risks or expected risks for participating in this study. There are no known direct benefits for participating in the study; however, the knowledge gained from this study may benefit the practice of shared governance in higher education and may also benefit future research efforts.

The 29-item online survey will take approximately 5-10 minutes of your time. By clicking on the following link https://www.surveymonkey.com/s/QV9YXLG you will be agreeing to participate in this study and will be automatically directed to the survey instrument. Please answer as candidly as possible.

If you have any questions about this research project, please feel free to contact me on my cell at 202-870-8513 or via email at eastont@ cua.edu or Dr. Richard Walls at 304-293-3335 or via email at richard.walls@ mail.wvu.edu. Thank you for considering my request.

Sincerely, 
Tanya Easton, M. A.

Doctoral Student

West Virginia University

\section{APPENDIX H: Research Study Participation Request Reminder (To ACA Faculty, Administrators, and Staff)}

Dear ACA Faculty, Administrators, and Staff:

Many thanks if you have already completed the online survey for my research study entitled, $A$ Study of Faculty, Administrative, and Staff Perceptions of the Climate for Shared Governance at Appalachian College Association Member Institutions.

If you haven't completed the survey, this is just a friendly reminder of your invitation to participate. Your participation is voluntary.

The West Virginia University IRB has approved the research study. All of your responses to this survey will remain anonymous and cannot be linked to you or your institution in any way. No identifying information about you will be collected.

The 29-item online survey will take approximately 5-10 minutes of your time. By clicking on the following link https://www.surveymonkey.com/s/QV9YXLG you will be agreeing to participate in this study and will be automatically directed to the survey instrument. Please answer as candidly as possible.

If you have any questions about this research project, please feel free to contact me on my cell at 202-870-8513 or via email at eastont@ cua.edu or Dr. Richard Walls at 304-293-3335 or via email at richard.walls@mail.wvu.edu. Thank you for considering my request.

Sincerely,

\section{Tamya Eastan}

Tanya L. Easton, M.A.

Doctoral Student

West Virginia University 